Universidade de São Paulo

Faculdade de Saúde Pública

\title{
Peptídeos do feijão caupi (Vigna unguiculata L. Walp) e metabolismo do colesterol: interação micelar, permeação celular e expressão gênica
}

Marcelo Rodrigues Marques

Tese apresentada ao Programa de pósgraduação em Nutrição em Saúde Pública para obtenção do título de Doutor em Ciências

Área de concentração: Nutrição em Saúde Pública

Orientador: Prof. Dr. José Alfredo Gomes Arêas

São Paulo

2017 


\title{
Peptídeos do feijão caupi (Vigna unguiculata L. Walp) e metabolismo do colesterol: interação micelar, permeação celular e expressão gênica
}

\author{
Marcelo Rodrigues Marques
}

Revisada em 03/05/2017

Tese apresentada ao Programa de pósgraduação em Nutrição em Saúde Pública para obtenção do título de Doutor em Ciências

Área de concentração: Nutrição em Saúde Pública

Orientador: Prof. Dr. José Alfredo Gomes Arêas

São Paulo

2017 
É expressamente proibida a comercialização deste documento, tanto na sua forma impressa como eletrônica. Sua reprodução total ou parcial é permitida exclusivamente para fins acadêmicos e científicos, desde que na reprodução figure a identificação do autor, título, instituição e ano da tese/dissertação. 


\section{DEDICATÓRIA}

À Valentina!

Dedico. 


\section{AGRADECIMENTOS}

A Fundação de Amparo à Pesquisa do Estado de São Paulo, pela bolsa recebida possibilitando a execução deste estudo.

Ao CNPq por me conceder bolsa de doutorado sanduíche.

Ao professor José Alfredo por sua imensa paciência, pela sua jovialidade e irreverência como profissional, pela preocupação em formar recursos humanos de qualidade e principalmente por depositar confiança em mim, muitas vezes mais até do que eu próprio depositaria.

À minha família, principalmente minha mãe, irmã, meus sobrinhos e esposa por estarem presentes quando precisei de carinho, compartilharam de todos os meus momentos de angústia, mas também de felicidade e realização que vivi durante minha pós-graduação.

À Professora Elisabeth Arêas por intermediar todo o processo da bolsa sanduíche, ser resolutiva e por confiar em meu trabalho junto ao grupo de pesquisa no exterior.

Aos professores Mario Hirata e Rosário Hirata, por me receber em seu laboratório (LABMAD) para execução das análises de biologia molecular e serem nossos parceiros nessa caminhada.

Ao Dr. Álvaro Cerda por introduzir o manejo a as técnicas de biomol e ao Dr. Gustavo Fontanari por acompanhar e discutir o desenho experimental e os resultados, sendo ambos fundamentais para execução dessa tese.

À Universidade Tecnológica de Eindhoven na pessoa da Prof ${ }^{\mathrm{a}}$. Ilja Voets, Dr ${ }^{\mathrm{a}}$ Neus Villanova e todo o seu grupo de pesquisa por me receber em seu laboratório e por me proporcionar a experiência de conviver com outras formas de trabalhar e pensar a ciência.

À professora Regilda Araújo por despertar o pesquisador escondido em minha personalidade.

Aos amigos do laboratório: Cíntia, Amanda, Nara, Bianka, Camila, Dr ${ }^{\mathrm{a}}$ Geni e $\mathrm{Dr}^{\mathrm{a}}$ Liânia pela capacidade de me confortar e me manter perseverante. 
À Rosana, não só pela competência indiscutível, mas também pelos momentos de descontração, apoio técnico, profissional e pessoal.

A grande amiga Érica Siguemoto por ser a pessoa que me ouvia durante o período que estava fora do meu laboratório e por compartilhar das mesmas angústias e das mesmas alegrias que a pós-graduação proporciona.

Aos funcionários da Faculdade de Saúde Pública que realizaram e continuam realizando todo o trabalho dos bastidores fundamentais para que esse momento acontecesse em especial Bastos, Eduardo, lara, Alessandra, Roseli e José Bezerra.

Ao Danilo Uchôa, Renato Danilo, Henry Morgan, Bruno Alisson bem como todos meus amigos que ficaram no Piauí e que mesmo longe continuam torcendo pelo meu sucesso.

À minha filha Valentina que mesmo sem saber, me ensinou a priorizar meus esforços, organizar melhor meu tempo e dar o devido valor ao trabalho e a família.

A todos aqueles que contribuíram para o êxito desse trabalho, pois, nada consegui sozinho. 
"O que perturba e intimida

O meu espírito forte

Não é a certeza da morte,

Mas a incerteza da vida."

Da Costa e Silva 


\section{RESUMO}

MARQUES,M.R. Peptídeos do feijão caupi (Vigna unguiculata L. Walp) e metabolismo do colesterol: interação micelar, permeação celular e expressão gênica.2017.87 p. Tese (Doutorado) - Faculdade de Saúde Pública, Universidade de São Paulo, São Paulo, 2017.

Introdução: As proteínas alimentares são fontes de peptídeos atuantes em vários processos metabólicos. Existem evidências de que a proteína do feijão caupi (Vigna unguiculata L. Walp) é capaz de reduzir o colesterol em hamsters e em humanos, porém, a permeabilidade após a digestão, o mecanismo de ação e a evidência direta da participação de peptídeos no metabolismo colesterol não são claros. Objetivo: Investigar a permeabilidade intestinal e avaliar o efeito nas vias luminal e endógena do metabolismo do colesterol de peptídeos provenientes de feijão caupi (Vigna unguiculata L. Walp). Metodologia: A permeabilidade dos peptídeos provenientes do caupi produzidos por hidrólise enzimática foi testada em linhagens de células Caco-2 usando placas Transwe/ $\mathbb{B}^{\mathrm{B}}$. Para investigar o efeito na via luminal, três peptídeos identificados na fração $\leq 3 \mathrm{kDa}$ do hidrolisado (LLNPDDEQL; FFFGQDGGSKGEE e LNL) foram testados na solubilização de colesterol e fosfatidilcolina, no tamanho das micelas de colesterol e interação com ácidos biliares in vitro. Para verificar o efeito no metabolismo endógeno, linhagens de células HepG2 foram incubadas com peptídeos sintéticos (MELNAVSVVHS e MELNAVSVVSH) identificados como resultado do ensaio de permeação nas células Caco-2. A expressão de RNAm dos transportadores de colesterol NPC1L1, ABCA1 e $A B C G 1$ foi realizada nas células Caco-2 e a expressão de HMGCR, SREBP2, $L D L R, L X R a, A M P K 1$ foi avaliada nas células HepG2. Resultados: A exposição das células Caco-2 à fração $\leq 3 \mathrm{kDa}$ do hidrolisado $(2,5$ e $5 \mathrm{mg} / \mathrm{mL})$ aumentou a expressão de $A B C G 1$ nos tempos $6 \mathrm{~h}$ e $12 \mathrm{~h}$. O níveis de RNAm dos genes SREBP2, HMGCR e LDLR reduziram nas HepG2 após 24h do tratamento com o peptídeo MELNAVSVVHS $(50 \mu \mathrm{M}$ e $100 \mu \mathrm{M})$. A fração $\leq 3 \mathrm{kDa}$ do hidrolisado e os peptídeos LLNPDDEQL; FFFGQDGGSKGEE e LNL foram capazes de reduzir a solubilidade do colesterol micelar in vitro em no máximo $42 \%$, bem como, provocaram mudanças estruturais ao interagirem com a fosfatidilcolina, com 
destaque ao peptídeo LNL ( $\approx 50 \%$ de ligação). O peptídeo $L N L$ foi o único capaz de promover a precipitação do colesterol em forma de cristais devido à interação com os ácidos biliares. Conclusões: $A$ fração $\leq 3 \mathrm{kDa}$ do hidrolisado e todos os peptídeos testados foram capazes de insolubilizar o colesterol in vitro. Constata-se que o mecanismo de competição pelo espaço intramicelar com o colesterol se dá pela interação com os componentes micelares e não diretamente com o colesterol. O peptídeo do feijão caupi MELNAVSVVHS foi permeável e foi capaz de reduzir a expressão do fator de transcrição SREBP2 (consequentemente reduzindo HMGCR e $L D L R)$.

Palavras-chave: Feijão caupi; peptídeos; permeabilidade; metabolismo do colesterol. 


\section{ABSTRACT}

MARQUES,M.R. Cowpea bean peptides (Vigna unguiculata L. Walp) and cholesterol: micellar interaction, cellular permeation and genic expression. 2017.87 p. Tese (Doutorado) - Faculdade de Saúde Pública, Universidade de São Paulo, São Paulo, 2017.

Introduction: Food proteins are sources of peptides acting in sevral metabolic processes. There is evidence that cowpea (Vigna unguiculata $\mathrm{L}$. Walp) protein is able to lower cholesterol levels in hamsters and humans, but its permeability after digestion, mechanism of action and direct evidences of peptide participation in cholesterol metabolism are not clear. Objective: To investigate the intestinal permeability and to evaluate the effect on the luminal and endogenous cholesterol metabolism pathways of peptides from cowpea (Vigna unguiculata L. Walp). Methods: The permeability of the cowpea peptides produced by enzymatic hydrolysis was tested on Caco-2 cell lines using Transwell® plates. To investigate the effect on the luminal pathway, three peptides identified in the $\leq 3 \mathrm{kDa}$ hydrolyzate fraction (LLNPDDEQL; FFFGQDGGSKGEE and LNL) were tested for in vitro cholesterol and phosphatidylcholine solubilization, cholesterol micelle size changing and interaction with bile acids. To verify the effect on endogenous metabolism, HepG2 cell lines were incubated with synthetic peptides (MELNAVSVVHS or MELNAVSVVSH) identified as a result of the permeation assay on Caco-2 cells. The mRNA expression of the cholesterol transporters NPC1L1, ABCA1 and ABCG1 was performed on Caco-2 cells and the expression of HMGCR, SREBP2, LDLR, LXRa, $A M P K 1$ was evaluated in HepG2 cells. Results: Exposure of Caco-2 cells to the $\leq 3$ $\mathrm{kDa}$ hydrolyzate fraction ( 2.5 and $5 \mathrm{mg} / \mathrm{mL}$ ) increased $A B C G 1$ expression at $6 \mathrm{~h}$ and $12 \mathrm{~h}$ times. The mRNA levels of the SREBP2, HMGCR and LDLR genes were reduced in HepG2 after 24h of treatment with the MELNAVSVVHS peptide (50 $\mu \mathrm{M}$ and $100 \mu \mathrm{M}$ ). The $\leq 3 \mathrm{kDa}$ of the hydrolyzate fraction and the peptides LLNPDDEQL; FFFGQDGGSKGEE and LNL were able to reduce the solubility of micellar cholesterol in vitro in a maximum of $42 \%$, as well as, caused structural changes when interacting with phosphatidylcholine, with emphasis on the LNL peptide $\approx 50 \%$ of binding). The LNL peptide alone was able to promote cholesterol precipitation in the form of crystals due to interaction with bile acids. Conclusions: The $\leq 3 \mathrm{kDa}$ hydrolysate fraction and all peptides tested were able to insolubilize cholesterol in 
vitro. It was observed that the mechanism of competition for the intramicellar space with cholesterol is given by the interaction with the micellar components and not directly with the cholesterol. The MELNAVSVVHS cowpea peptide was permeable and was able to reduce the expression of the SREBP2 transcription factor (thereby reducing HMGCR and LDLR).

Key words: cowpea bean, peptides, permeability, cholesterol metabolism. 


\section{SUMÁRIO}

1. INTRODUÇÃO

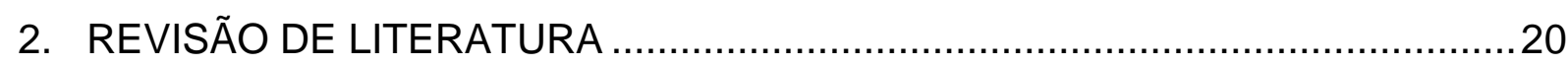

2.1. Peptídeos alimentares: capacidade bioativa e absorção intestinal..................20

2.2. Absorção de micelar de colesterol e organização estrutural das micelas .......24

2.3. Regulação genética do transporte celular e da biossíntese do colesterol .......28

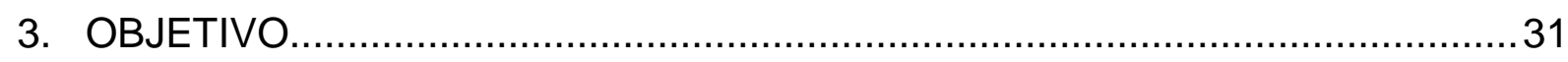

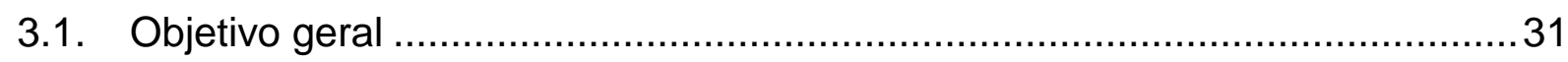

Investigar o transporte intestinal e avaliar o efeito nas vias luminal e endógena do metabolismo do colesterol de peptídeos provenientes de feijão caupi (Vigna

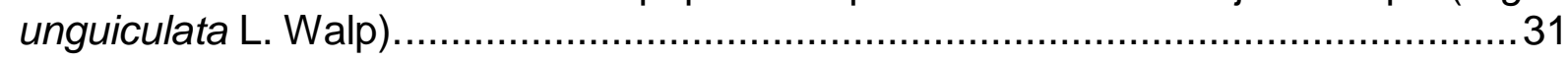

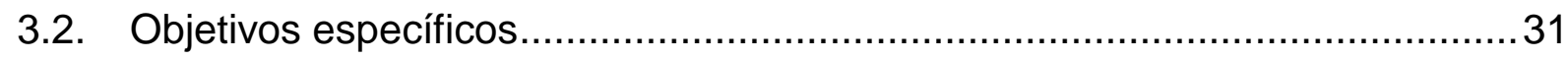

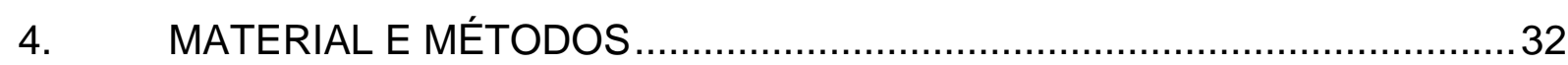

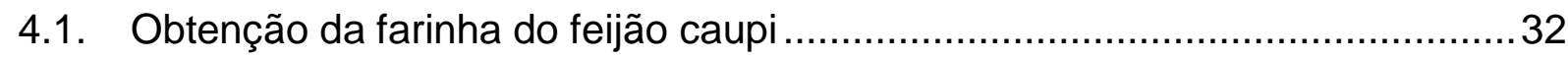

O feijão caupi (Vigna unguiculata L. Walp) cultivar BRS-Milênio, foi fornecido pela EMBRAPA transferência de tecnologia escritório de Petrolina, Pernambuco. Os grãos de feijão foram triturados e tamisados (peneira de 0,42 mm), gerando a farinha de feijão que foi utilizada para o processo de isolamento de proteína. .......................32

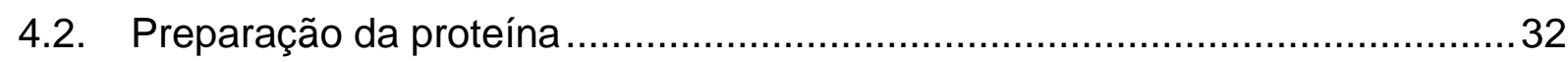

4.2.1. Isolamento proteico das farinhas de feijão caupi .........................................32

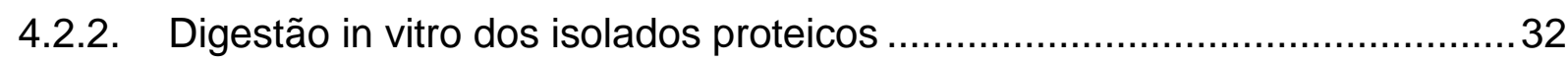

4.2.3. Determinação do grau de hidrólise......................................................... 33

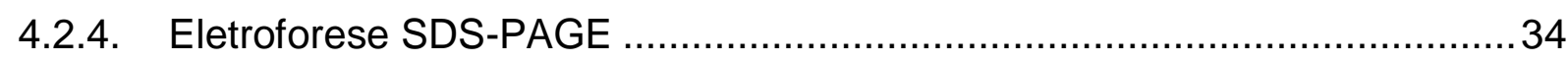

4.3. VIA LUMINAL: mudanças químicas e estruturais nas micelas de colesterol...34

4.3.1. Preparação das micelas de colesterol.....................................................36

4.3.2. Espectroscopia de fluorescência: confirmação da formação de micelas e

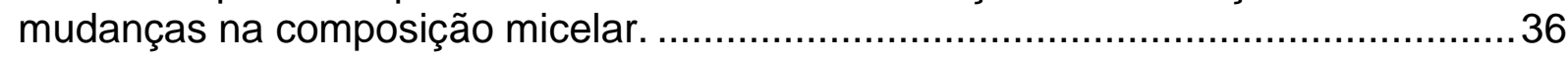

4.3.3. Ensaio de solubilização micelar de colesterol ................................................. 37

4.3.4. Mudança no tamanho das micelas de colesterol: espalhamento dinâmico de

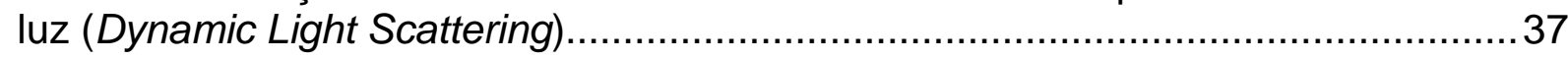

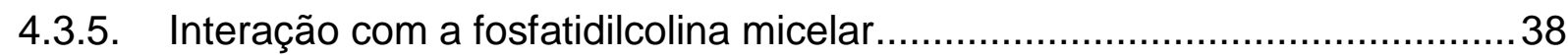

4.3.6. Ligação do hidrolisado e peptídeos com ácidos biliares ..............................38

4.3.7. Separação e quantificação da fração de cristais de colesterol......................39

4.4. VIA ENDÓGENA DO COLESTEROL: permeação celular, expressão gênica de transportadores e da biossíntese do colesterol. ...................................................39

4.4.1. Condições de cultivo de linhagens Caco-2 e HepG2 .................................. 39 
4.4.2. Ensaio de citotoxicidade. 40

4.4.3. Ensaio de permeação celular através da monocamada de células Caco-2.40

4.4.4. Sequenciamento "de novo" de peptídeos permeados através das células Caco-2 41

4.4.5. Abordagem "In Silico" para predição de bioatividade das sequencias peptídicas.

4.4.6. Tratamento das células HepG2 com análogos sintéticos identificados no compartimento basolateral da monocamada de Caco-2.

4.4.7. Análise da expressão gênica por qPCR em tempo real 43

4.5. Tratamento estatístico 45

5. Resultados e discussão .46

5.1. Caracterização da proteína e da fração $\leq 3 \mathrm{kDa}$ do hidrolisado de feijão caupi46

5.2. VIA LUMINAL: mudanças químicas e estruturais nas micelas de colesterol...47

5.2.1. Confirmação da formação de micelas e mudanças no tamanho micelar .....47

5.2.2. Solubilização micelar do colesterol in vitro......................................... 51

5.2.3. Solubilização micelar da fosfatidilcolina ............................................. 54

5.2.4. Interação da fração $\leq 3 \mathrm{kDa}$ do hidrolisado e peptídeos com ácidos biliares56

5.2.5. Separação e quantificação da fração de cristais de colesterol. .59

5.3. VIA ENDÓGENA: permeação celular, expressão gênica de transportadores e da biossíntese do colesterol 62

5.3.1. Permeação celular através da monocamada de células Caco-2 62

5.3.2. Expressão gênica dos transportadores NPC1L1, ABCA1 e ABCG1 em células Caco-2.. 64

5.3.3. Efeito do peptídeo permeado na expressão dos genes $H M G C R, L D L R$, $A M P K 1, S R E B P 2$ e $L X R \alpha$ em células HepG2.. 67

6. Conclusões. 72

7. Referências .73 


\section{LISTA DE TABELAS}

Tabela 1:Screening de sequências peptídicas do hidrolisado de feijão caupi e sua potencial atividade biológica, propriedades físico-químicas e fonte proteica.

Tabela 2: Peptídeo presente na parte basolateral e seu potencial de atividade biológica, propriedades físico-químicas e fonte proteica. 


\section{LISTA DE FIGURAS}

Figura 1: Vias de absorção de peptídeos pela mucosa intestinal de humanos em condições fisiológicas normais.

Figura 2: Representação esquemática da estrutura molecular das micelas mistas. Modelo de "concha radial".

Figura 3: Diagrama de fase ternário do equilíbrio colesterol-taurocolato e fosfatidilcolina. Embaixo do diagrama é mostrada a razão de fosfolipídeo/ácidos biliares em $\mathrm{pH}$ e temperaturas fisiológicas.

Figura 4: Fluxograma geral dos experimentos.

Figura 5: Eletroforese SDS-PAGE com gel 10\% e $50 \mu \mathrm{g}$ em proteína de feijão caupi: 1- marcador de peso molecular, 2-Farinha integral, 3 - farinha desengordurada; 4 isolado proteico, 5 - hidrolisado, 6 - fração $\leq 3 \mathrm{kDa}$ do hidrolisado.

Figura 6: Espectro de emissão de fluorescência do vermelho do nilovermelho do nilo na presença da fração $\leq 3 \mathrm{kDa}$ do hidrolisado. O tampão também contém taurocolato de sódio.

Figura 7: Espectro de emissão de fluorescência do vermelho do nilovermelho do nilo na presença de $1000 \mu \mathrm{g} / \mathrm{mL}$ de cada peptídeo encontrado no hidrolisado total. O tampão também contém taurocolato de sódio.

Figura 8: Efeito da fração $\leq 3 \mathrm{kDa}$ do hidrolisado da proteína do feijão caupi no tamanho das micelas de colesterol (média \pm DP).

Figura 9: Efeito dos peptídeos do caupi no tamanho das micelas de colesterol. (média $\pm \mathrm{DP}$ ). $\left(^{*}\right) \mathrm{p}<0,05$ comparado à micela padrão pelo teste $t$-Student.

Figura 10: Percentual de solubilização do colesterol na presença da fração $\leq 3 \mathrm{kDa}$ do hidrolisado de feijão caupi comparado à micela padrão (sem adição de hidrolisado). 52

Figura 11: Percentual de solubilização do colesterol na presença de três peptídeos sintéticos análogos aos provenientes do feijão caupi comparado à micela padrão, sem adição de peptídeos. .53

Figura 12: Percentual de solubilização de fosfatidilcolina na presença da fração $\leq 3 \mathrm{kDa}$ do hidrolisado de feijão caupi comparado à micela sem adição de 
hidrolisado (média $\pm \mathrm{DP}) .\left({ }^{*}\right) \quad p<0,05$ comparado à micela padrão pelo teste $t$ Student.

Figura 13: Percentual de solubilização de fosfatidilcolina na presença de três peptídeos sintéticos análogos aos provenientes do feijão caupi comparado à micela padrão, sem adição de peptídeos (média $\pm \mathrm{DP}$ ). $\left(^{*}\right) \mathrm{p}<0,05$. teste $t$-Student. .55

Figura 14: Interação da fração $\leq 3 \mathrm{kDa}$ do hidrolisado com ácidos biliares das micelas de colesterol. A colestiramina foi utilizada como controle positivo (média $\pm \mathrm{DP}) .\left(^{*}\right) \mathrm{p}<0,05$ comparado à micela padrão pelo teste $t$-Student. .57

Figura 15: Interação de três peptídeos sintéticos análogos aos provenientes do feijão caupi com ácidos biliares das micelas de colesterol. A colestiramina foi utilizada como controle positivo (média $\pm \mathrm{DP}$ ). $\left(^{*}\right) \mathrm{p}<0,05$ comparado à micela padrão pelo teste $t$-Student.

Figura 16: Quantificação de cristais de colesterol formados na presença e na ausência da fração $\leq 3 \mathrm{kDa}$ do hidrolisado (média $\pm \mathrm{DP}$ ). $\left(^{*}\right) \mathrm{p}<0,05$ comparado à micela padrão na ausência de hidrolisado $(0 \mathrm{mg} / \mathrm{mL})$ pelo teste $t$-Student. 60

Figura 17: Quantificação de cristais de colesterol formados na presença e na ausência de três peptídeos sintéticos análogos aos provenientes do feijão caupi (média $\pm \mathrm{DP}$ ). $\left({ }^{*}\right) \mathrm{p}<0,05$ comparado à micela padrão pelo teste $t$-Student.

Figura 18: Percentual de viabilidade celular das linhagens Caco-2 na presença de duas concentrações da fração $\leq 3 \mathrm{kDa}$ do hidrolisado em diferentes tempos. (Média $\pm \mathrm{DP})$. .65

Figura 19: Expressão de RNAm dos gene NPC1L1 (A), ABCA1 (B) e ABCG1 (C) sob diferentes condições de tempo e concentração de hidrolisado. (Média \pm Erro Padrão). (*) $\mathrm{p}<0,05$ comparado ao controle; (\#) $\mathrm{p}<0,05$ comparando diferentes tempos na mesma concentração. .66

Figura 20: Percentual de viabilidade celular das linhagens HepG2 na presença de duas concentrações do peptídeo MELNAVSVVHS em diferentes tempos. (Média \pm DP). .68

Figura 21: Percentual de viabilidade celular das linhagens HepG2 na presença de duas concentrações do peptídeo MELNAVSVVSH em diferentes tempos. (Média \pm DP) 69

Figura 22: Expressão de RNAm dos gene SREBP2 (A), AMPK1 (B) e LXRa (C), HMGCR (D), LDLR (E) sob diferentes condições de tempo e concentração do peptídeo MELNAVSVVSH. (Média \pm Erro Padrão). 


\section{LISTA DE ABREVIATURAS E SIGLAS}

\begin{tabular}{|c|c|}
\hline Alanina & Ala \\
\hline Cisteína & Cys \\
\hline Ácido Aspártico & Asp \\
\hline Ácido Glutâmico & Glu \\
\hline Fenilalanina & Phe \\
\hline Glicina & Gly \\
\hline Histidina & His \\
\hline Isoleucina & Ile \\
\hline Lisina & Lys \\
\hline Leucina & Leu \\
\hline Metionina & Met \\
\hline Asparagina & Asn \\
\hline Prolina & Pro \\
\hline Glutamina & Gln \\
\hline Arginina & Arg \\
\hline Serina & Ser \\
\hline Treonina & Thr \\
\hline Valina & Val \\
\hline Triptofano & Trp \\
\hline Tirosina & Tyr \\
\hline
\end{tabular}


ABCA1 Cassete de ligação com ATP sub familia A membro 1

ABCG1 Cassete de ligação com ATP sub-familia G membro 1

ACAT-2 acil-CoA colesterol aciltransferase

AMPK1 Proteína quinase ativada por adenosina monofosfato 1

ApoA-I apolipoproteína Al

ApoB-100 apolipoproteína B-100

cDNA Ácido desoxirribonucleico complementar

DPP-IVECA Dipepditil aminopeptidase IV

ECA Enzima conversora de angiotensina

HDL Lipoproteína de alta densidade

HMG-CoA 3-Hidroxi-3-metilglutaril coenzima A

HMGCR 3-Hidroxi-3-metilglutaril coenzima A redutase

IDL Lipoproteína de densidade intermediária

LDL Lipoproteína de baixa densidade

LDLR Receptor de LDL

LXRa Liver $X$ receptor alfa

MTP proteína de transferência microssomal

NPC1L1 Niemann-Pick C1-Like 1

OATP polipeptídeos transportadores de ânions orgânicos

PTS Sistema de transporte de peptídeos

RNAm RNA mensageiro

RNA Ácido ribonucleico

SREBP1c Proteínas de ligação do elemento de regulação do esterol 1c

SREBP2 Proteínas de ligação do elemento de regulação do esterol 2

SDS-PAGE Eletroforese em gel de poliacrilamida sódio-dodecil-sulfato

VLDL Lipoproteína de muito baixa densidade 


\section{INTRODUÇÃO}

A hiperlipidemia, um distúrbio no metabolismo, é caracterizada pela elevação da concentração de colesterol plasmático e lipoproteínas de baixa densidade e a diminuição das lipoproteínas de alta densidade, contribuindo para que as doenças cardiovasculares sejam atualmente uma das maiores causas de morte no mundo ocidental. A complexidade etiológica das hiperlipidemias se justifica pelo fato de que a concentração de colesterol plasmático no organismo humano ser regulada por diversas vias metabólicas integradas e com efeitos compensatórios entre si. Dividemse tradicionalmente em três vias principais: a biossíntese endógena, a absorção dietética e o transporte reverso com remoção do colesterol circulante com excreção nas fezes (SUDHAHAR et al., 2006; AFONSO, 2010).

Dentro do organismo humano, a absorção, a compartimentalização e o transporte de colesterol é uma homeostase complexa. A absorção do colesterol é um processo de múltiplos passos, dentre os quais os mais importantes são (1) quebra dos ésteres de esterol dietético em esteróis livres no lúmen intestinal, (2) a solubilização do colesterol não esterificado em uma fase emulsificada de gordura dentro das micelas mistas no lúmen e (3) transporte do colesterol através da barreira da mucosa intestinal (SMET et al., 2012).

A partir daí, uma série de outras reações que se seguem são responsáveis por manter a estabilidade da concentração endógena de colesterol, ao equilibrar fontes dietéticas e a produção endógena. Por isso, as mudanças na atividade de várias proteínas transportadoras (Quilomícrons, VLDL, IDL, LDL, HDL), de membrana (proteínas ATP e NPC) e fatores de transcrição no fígado (SREBP2, SREBP1c, LXR) também refletem indiretamente essa homeostase (GOLDSTEIN E BROWN, 1990; FITZGERALD et al., 2011).

Nos últimos 20 anos, os próprios alimentos e ingredientes alimentares vêm sendo estudados com o intuito de prevenir e reduzir do risco do desenvolvimento das dislipidemias. Conhecidos como alimentos funcionais, essas matrizes alimentares possuem variados compostos responsáveis por efeitos fisiológicos benéficos (MARQUES et al., 2012). Uma série de frações peptídicas codificadas dentro de proteínas alimentares e resultantes da digestão por enzimas naturais e sintéticas foram identificadas e descritas como antimicrobianas, antifúngicas, antioxidantes, 
antitrombóticas, imunomodulatórias, opióides e também hipocolesterolêmicas (PIMENTA E LEBRUN, 2007; FERREIRA et al., 2011; HERNANDEZ-LEDESMa et al., 2011).

Sendo assim, o potencial hipocolesterolêmico de algumas leguminosas já é conhecido. O consumo da proteína de soja é capaz de reduzir o colesterol sanguíneo, provavelmente através dos peptídeos encriptados na proteína, liberados após uma digestão enzimática in vitro ou in vivo, (POTTER, 1998; PAK et al., 2005).

Existem teorias acerca dos mecanismos relacionados à ação de peptídeos no metabolismo do colesterol, como por exemplo, agindo de forma similar a hormônios, inibindo competitivamente à enzima 3-Hidroxi-3-metilglutaril coenzima A redutase (HMGCR) no fígado, suprimindo a expressão de genes que estariam relacionados ao metabolismo de ácidos graxos e impedindo a solubilidade micelar do colesterol no lúmen, levando à redução de lipídeos plasmáticos e hepáticos (ARNOLDI et al., 2001; PAK et al., 2006; FROTA, 2007; SOARES, 2008). Contudo, para que os peptídeos consigam alcançar os órgãos-alvo após o consumo por via oral, é necessário ultrapassar a barreira da mucosa intestinal e os vários fatores associados que interferem na biodisponibilidade (WASAN, 2002).

Portanto, o presente trabalho propôs investigar a permeabilidade intestinal e avaliar o efeito nas vias luminal e endógena do metabolismo do colesterol de peptídeos provenientes de feijão caupi (Vigna unguiculata L. Walp).

\section{REVISÃO DE LITERATURA}

\subsection{Peptídeos alimentares: capacidade bioativa e absorção intestinal}

Em 1991, no Japão foi aprovada a legislação que definiu a política de "Alimentos para uso específico na Saúde" (Foods for Specified Health Use/FOSHU), regulamentando o uso de alimentos para tratamento de saúde e nessa oportunidade foi proposto o conceito de alimento funcional. Os produtos com um rótulo FOSHU desde então, são certificados no que diz respeito à sua atividade farmacêutica ou bioativa (ARAI, 2000).

Tradicionalmente, a proteína na dieta tem sido considerada como uma fonte de aminoácidos essenciais para a manutenção celular, crescimento e energia. Porém, recentemente proteínas dietéticas têm sido reconhecidas, adicionalmente, pelas suas 
propriedades bioativas (RYDER et al., 2016). Na literatura são descritas frações peptídicas antimicrobianas, antifúngicas, antioxidantes, antitrombóticas, imunomodulatórias, opióides e também hipocolesterolêmicas (PIMENTA E LEBRUN, 2007; FERREIRA et al., 2011; HERNANDEZ-LEDESMA et al., 2011). Na lista da categoria 2 de produtos FOSHU já está incluso peptídeos derivados de soja, por serem capazes de controlar o nível de colesterol sanguíneo (ARAI, 2000).

Assim, peptídeos bioativos são definidos como sendo sequências curtas de aminoácidos que possuem uma ou mais atividades biologicamente significativas quando dentro do corpo humano (LAFARGA e HAYES, 2014). Estas sequências peptídicas não apresentam qualquer bioatividade quando dentro na sequência da proteína intacta de maneira que primeiro tem de ser excisado, por meio de hidrólise catalisada com uma ou mais proteases, por fermentação, ou por uma combinação e por conta disso também podem ser chamados de "criptídeos"(IVANOV et al., 1997; KORHONEN e PIHLANTO, 2006).

Em teoria, o pequeno tamanho torna as sequências peptídicas menos propensas à degradação no estômago e aumenta a sua biodisponibilidade. Particularmente, quanto maior for a quantidade de resíduos hidrofóbicos na sequência do peptídeo maior sua absorção. Porém, no trato grastrointestinal é abundante a presença de exo/endopeptidases capazes de degradar as biomacromoléculas. Outros fatores como o tempo de retenção e trânsito, a exposição a diferentes condições de $\mathrm{pH}$, a interação com alimentos e muco, o local de absorção específica e a permeabilidade intestinal também afetam a biodisponibilidade dos peptídeos (PAWAR et al., 2014).

Renukuntla et al. (2013) afirmam existir 3 possíveis vias de entrada de peptídeos pela barreira intestinal: 1 - paracelular (através das "tight junctions" entre as células, sem consumo de energia); 2 - transcelular (através do epitélio, por difusão passiva); 3 - por endocitose (no momento do reconhecimento pelos receptores ou carreador-mediado). Aminoácidos livres, di e tripeptídeos podem ser transportados pelos transportadores de peptídeo 1 (PepT1) localizados na membrana apical do duodeno e jejuno enterócitos, num transporte que depende do potencial de membrana e de $\mathrm{pH}$ pelo fato de que o PepT1 também são co-transportadores de $\mathrm{H}^{+}$(GLEESON et al., 2015) (Figura 1).

Figura 1: Vias de absorção de peptídeos pela mucosa intestinal de humanos em condições fisiológicas normais. 


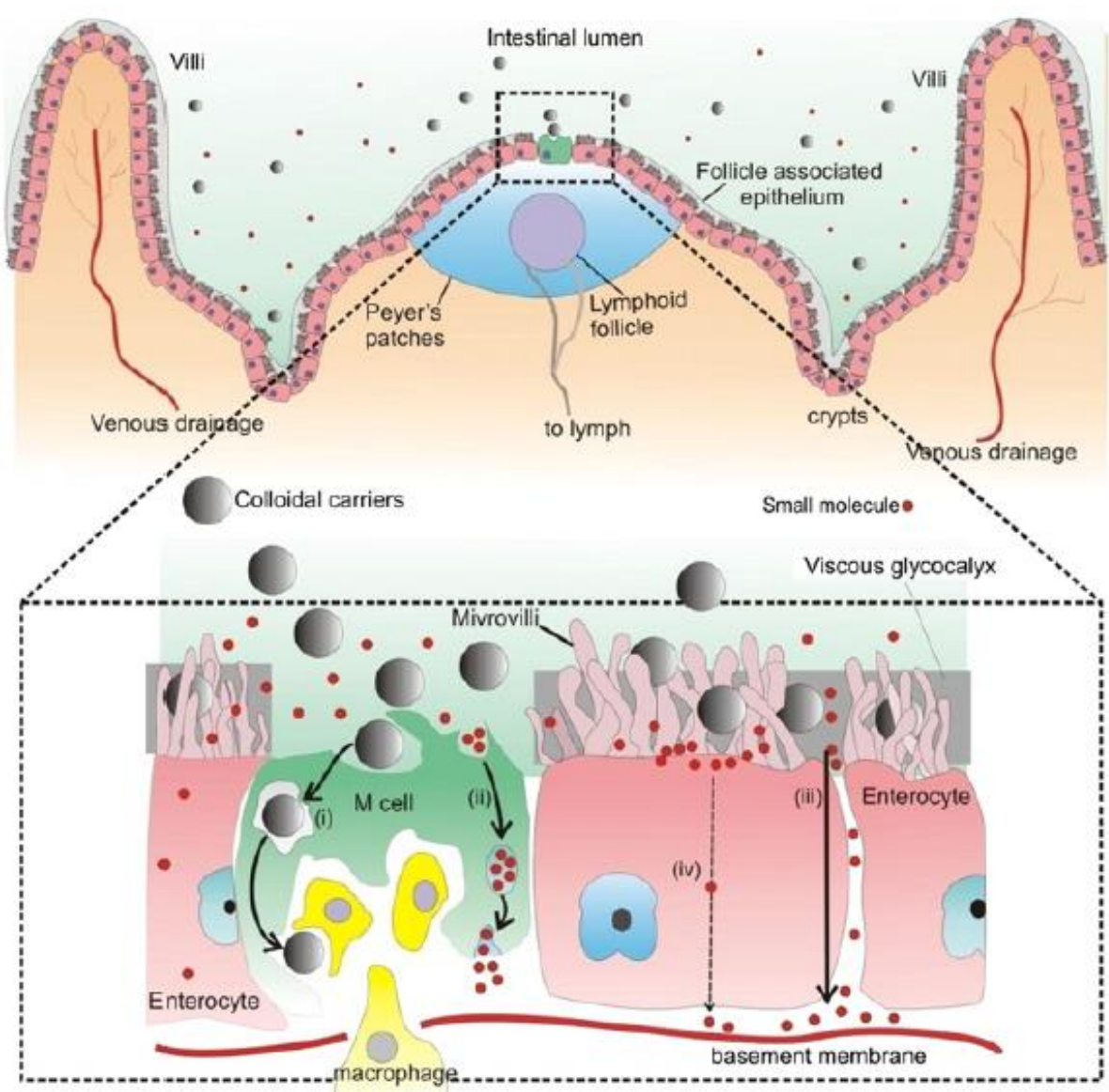

Fonte: Pawar et. al, adaptado (2014).

Peptídeos maiores (maiores que 5 resíduos) tendem a exercer a sua atividade biológica, sem entrar na célula do epitélio intestinal, mecanismo característico dos peptídeos que afetam a função gastrointestinal e alérgenos alimentares. Os alergenos parecem aumentar a permeabilidade das células epiteliais para outros peptídeos através da reorganização do citoesqueleto alterando as "tigth juctions" propiciando o transporte paracelular (TANABE, 2012).

No transporte mediado por carreadores a célula intestinal se utiliza dos transportadores de membrana. Expressas em superfícies celulares apicais e basais, sua função é facilitar o movimento dos peptideos através das membranas celulares. Tanto o transporte mediado por receptores quanto por carreadores de membrana são internalizados principalmente nas células M (microfold cells) e por processos de endocitose (fagocitose e pinocitose). Fisiologicamente, atuam como células imunovigilantes responsáveis por absorver vários tipos de antígenos, macromoléculas, microorganismos, e certos tipos de partículas que são então 
transportados para o sistema linfoide e induzir respostas imunes. As células $M$ possuem uma capacidade transcitótica mais elevada em comparação aos enterócitos e podem transportar uma grande variedade de materiais, incluindo proteínas e sistemas coloidais (MAESTRI et al., 2016).

O transporte mediado por receptor implica uma interação específica entre 0 receptor e moléculas específicas, nesse caso os peptídeos. Existem vários trasportadores de peptídeos maiores de 10 resíduos descritos em humanos. A barreira hemato-encefálica é um dos exemplos. Diferentes sistemas de transporte de peptídeos têm sido descritos (ex: PTS-1 a PTS-4). Alguns desses transportadores são conhecidos como polipeptídeos transportadores de ânions orgânicos (OATPs), uma família de transportadores poliespecíficos. O transportador OATP-A (SLC21A3) é conhecido por mediar o transporte de peptídeos opióides através da barreira hematoencefálica. A ligação com os receptores e carreadores desencadeia um agrupamento de reações em cascata que provoca a mudança na orientação dos lípideos de membrana que promovem a invaginação da membrana celular. A estrutura vesicular é completada pela compressão do compartimento de membrana. Contudo, não se conhecem ao certo transportadores específicos para peptídeos alimentares, apesar de existir a possibilidade de absorção de grandes peptídeos (PAWAR et al., 2014; MAESTRI et al., 2016).

Monocamadas de células Caco-2 cultivadas in vitro, derivadas de carcinoma coloretal humano são atualmente utilizadas para avaliar a absorção e o transporte de peptídeos (PICARIELLO et al., 2013). Tal metodologia é largamente empregada no estudo de absorção de fármacos e para verificar o efeito nos transportadores de colesterol, pois o sistema modelo mimetiza enterócitos humanos (GENVIGIR, F. D. et al., 2011).

Alguns alimentos já são conhecidos por serem capazes de exercerem função bioativa relacionada a fração proteica. Lammi et. al. (Lammi et al., 2016) fizeram uma varredura de peptídeos provenientes da soja (Glycine max e do tremoço (Lupinus albus) por modelagem in vitro e conseguiram predizer a capacidade de algumas sequencias (Soja 1 -IAVPTGVA, Soja 2 - YVVNPDNDEN), Soja 3 YVVNPDNNEN, tremoço 1 -LTFPGSAED, tremoço 2 -LILPKHSDAD, and tremoço 3 GQEQSHQDEGVIVR) de inibir a enzima Dipepditil aminopeptidase IV (DPP-IV). A inibição da DPP-IV é tratamento coadjuvante para diabetes mellitus tipo II, por impedir a degradação das incretinas reguladoras de glicemia. 
Resíduos de proteína da indústria de carnes foram avaliados quanto a capacidade antioxidante e inibidora de enzima conversora de angiotensina (ECA). O estudo em questão comparou a capacidade bioativa pela cisão da proteína gerada pelos processos de aquecimento, tenderização e uso de proteases comerciais com os resultados gerados pela quebra enzimática humana. Os hidrolisados de proteínas miofibrilares submetidoa a açõa enzimática do Bacillus foi a mais promissora, coparada ao fámaco captopril (RYDER et al., 2016).

\subsection{Absorção de micelar de colesterol e organização estrutural das micelas}

O colesterol entra no intestino delgado a partir de duas fontes: a dieta e a bile. A ingestão dietética de colesterol é de cerca de $300 \mathrm{mg} /$ dia enquanto a bile contribui com 800-1400 mg/dia. A absorção de colesterol e de outros lipídeos depende da sua capacidade para formar micelas dentro do lúmen intestinal. Micelas são agregados lipídicos que se formam quando uma concentração crítica de lípidos provenientes da bile (ex. fosfolípideos, colesterol) se mistura com lipídeos provenientes da dieta (triglicérídeos, fosfolípideos e colesterol). Os ácidos biliares atuam como agentes sufactantes permitindo que os lípideos se solubilizem num ambiente aquoso, facilitando sua absorção pelo enterócito. Além disso, a proporção de dos ácidos biliares, fosfolípidos e colesterol na vesícula biliar devem ser mantidos dentro em uma proporção e concentrações específicas para evitar a formação de cálculos biliares e otimizar a formação de micelas no lúmen. Evidências sugerem que o colesterol biliar, devido à sua associação inerente com os ácidos biliares, é absorvido de forma mais eficaz do que o colesterol dietético (CARR e JESCH, 2006; LECERF e DE LORGERIL, 2011).

No total $1000-2000 \mathrm{mg}$ de colesterol chega ao lúmen e pode ser absorvido, porém, somente o colesterol não esterificado está disponível para formação micelar e consequentemente para absorção. A absorção de colesterol pode ser dividida em 7 passos: (1) quebra dos ésteres de esterol dietético em esteróis livres no lúmen intestinal, (2) a solubilização do colesterol não esterificado em uma fase emulsificada de gordura e em micelas mistas no lúmen e (3) transporte do colesterol através da barreira da mucosa intestinal. Posteriormente, (4) internalização para o meio intracellular e (5) esterificação pela acil-CoA colesterol aciltransferase (ACAT-2) (6) incorporação do colesterol pelos quilomícrons por meio da proteína de transferência 
microssomal (MTP) e (7) liberação no sistema linfático (LECERF e DE LORGERIL, 2011; SMET et al., 2012).

Do ponto de vista da saúde, a eficiência da absorção de colesterol é de grande interesse, pois, estudos com humanos e animais têm correlacionado a absorção de colesterol com a concentração de colesterol total e LDL (LEE-RUECKERT et al., 2013). O estudo da solubilidade do colesterol em micelas de sais biliares é importante para entender a disponibilidade de colesterol para absorção intestinal e para desenvolver estratégias para diminuir a internalização pelo eptélio. Este tema vem sendo alvo de várias pesquisas devido a relação entre doenças e alta concentração de colesterol plasmático (Coreta-Gomes et al., 2012). Muitos componentes dietéticos que reduzem a absorção de colesterol o fazem se ligando aos ácidos biliares ou de outra forma perturbando a sua capacidade para formar micelas. Em condições normais, todos os componentes da micela - exceto colesterol - são transportados para o enterócito e absorvidos com eficiência (90-100 \%); a absorção de colesterol, ao contrário, é de 50-60\% (MATTHAN e LICHTENSTEIN, 2004).

Estudos demonstram a presença no lúmen de uma variedade de partículas de diferentes tamanhos após uma refeição. Dois grandes agregados macromoleculares parecem estar envolvidos com a absorção de lipídeos dentro do lúmen intestinal: As vesículas unilamelares e as micelas mistas. As vesículas unilamelares são partículas maiores, pobres em ácidos biliares possuindo várias centenas de angstroms de diâmetro e contêm fosfolipídeos, ácidos graxos, monoglicerídeos e colesterol. As micelas mistas são muito mais ricas em ácidos biliares, menores, com diâmetros inferiores a 100 angstroms e são compostos principalmente de ácidos biliares e colesterol com menores quantidades de fosfolipídeos (WOOLLETT et al., 2006).

Os ácidos biliares livres também existem em concentrações muito baixas em formas monoméricas. Estes diferentes tipos de agregados parecem estar presentes no fluido intestinal de forma dinâmica, deslocando partículas de diferentes tamanhos constantemente para manter o equilíbrio da solução. Quando as concentrações de ácidos biliares excedem a concentração micelar crítica (CMC), as micelas se formam apenas por ácidos biliares (WOOLLETT et al., 2006).

As micelas mistas de colesterol (formadas por mais de um componente lipídico) possuem estruturas variáveis a depender da sua composição. A composição da monocamada de fosfolípido compreende principalmente de fosfatidilcolina, fosfatidiletanolamina e, em menor grau, fosfatidilinositol e lisofosfolípidos. Cada um 
destes fosfolípidos tem propriedades interfaciais específicas que determinam a sua capacidade para estabilizar emulsões. Por exemplo, a fosfatidilcolina tem uma forma cilíndrica e proporciona cobertura da área superficial e reduz consideravelmente a superfície de tensão (THIAM et al., 2013).

A simulação computacional realizada por Marrink e Mark (2002) confirmou a estrutura em forma de "concha radial" das micelas mistas. A simulação mostrou que as moléculas de fosfolípideo são orientadas radialmente e as moléculas de sais biliares postam-se na superfície preenchendo o espaço entre os grupos polares dos fosfolípídeos, orientando-se paralelamente à superfície. Os sais biliares ocasionalmente penetram no interior da micela, mas mantêm sempre a cadeia lateral iônica na fase aquosa.

Figura 2: Representação esquemática da estrutura molecular das micelas mistas. Modelo de "concha radial".
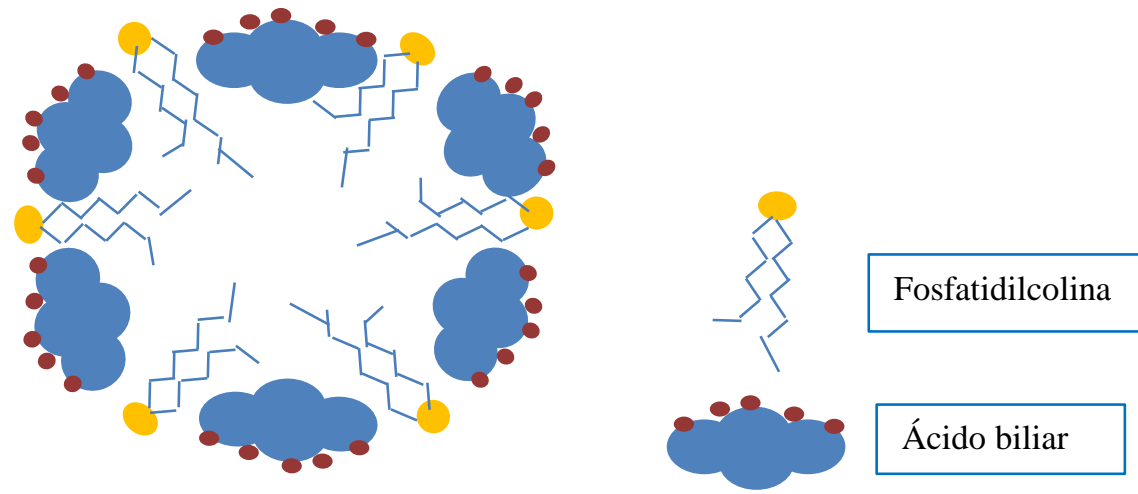

Fonte: Marques, M.R. (2017).

As pesquisas de Carey e colaboradores (HERNELL et al., 1990; DONOVAN et al., 1991; WANG e CAREY, 1996) acerca da formação e metabolismo da bile in vivo e in vitro, levaram a elucidação da importância da composição das micelas de colesterol para a formação tanto dos cálculos biliares quanto formação das micelas e vesículas, ressaltando a interação dinâmica entre elas. A precipitação do colesterol obedece a um comportamento físico-químico, com base na termodinâmica da mistura colesterol-ácidos biliares-fosfatidilcolina e na razão da concentração de ácidos biliares-fosfatidilcolina (Figura 3). 
Figura 3: Diagrama de fase ternário do equilíbrio colesterol-taurocolato e fosfatidilcolina. Embaixo do diagrama é mostrada a razão de fosfolipídeo/ácidos biliares em $\mathrm{pH}$ e temperaturas fisiológicas.

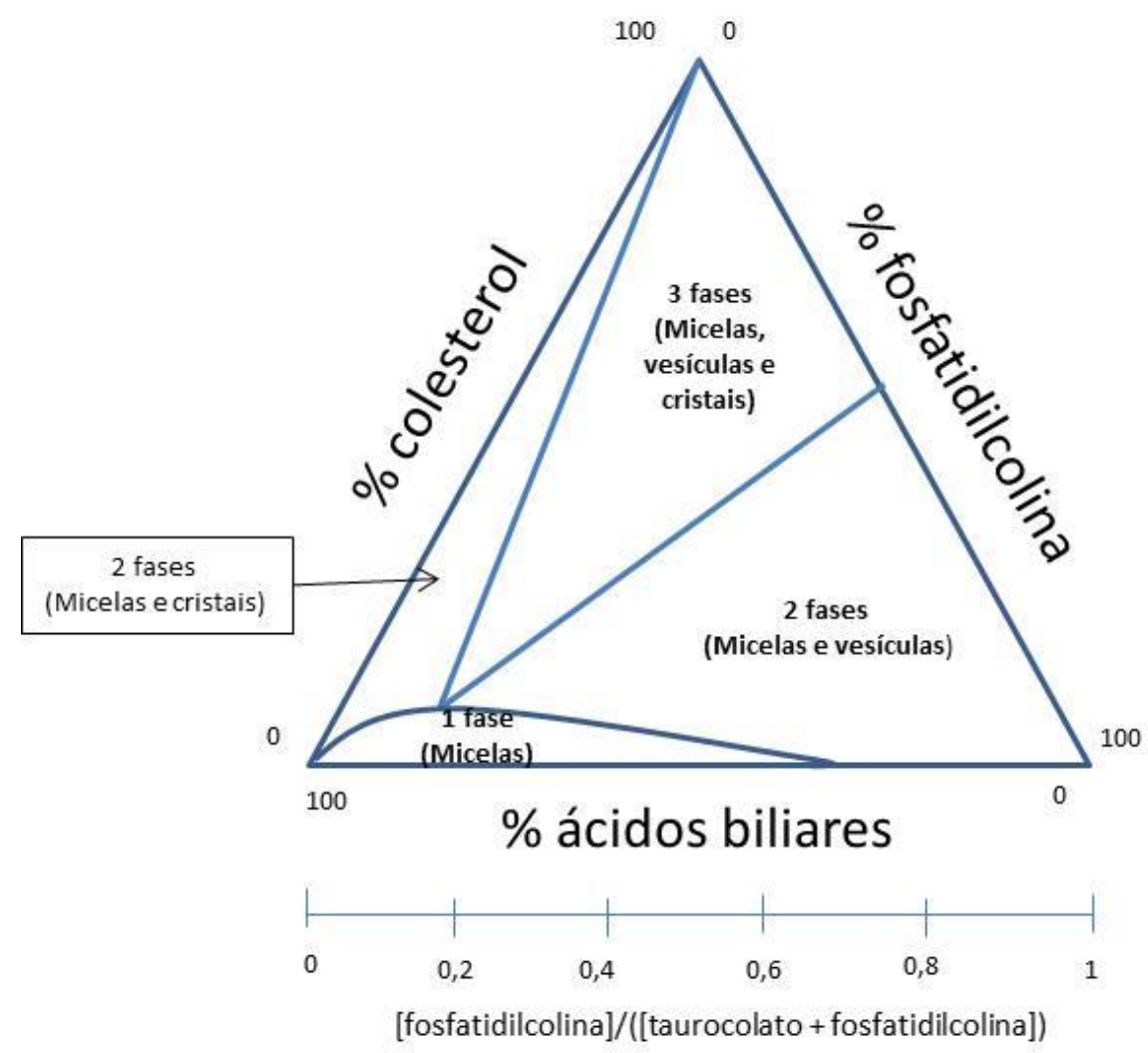

Fonte: Wang e Carey, traduzido e adaptado (1996).

Independente da concentração de colesterol e da composição e lipídeos das micelas, a razão fosfolipídeos/ácidos biliares é fundamental na formação de cristais de colesterol. Em caso de excesso de sais biliares (razão $\leq 0,2$ ) os cristais precipitam em velocidades maiores. Em caso de grandes quantidades de fosfolipídeos a cristalização ocorre mais lentamente. Em casos de excesso de fosfolipídeos na composição micelar, a precipitação não acontece e o colesterol é totalmente solubilizado nas fases micelares e vesiculares (MOSCHETTA et al., 2001).

Dada essa importância, o sequestro de ácidos biliares no trato gastrointestinal vem sendo estudado como fora de se combater a dislipidemia. Os ácidos biliares 
primários são produtos de catabolismo do colesterol hepático, que são secretados no cólon onde as atividades microbianas os convertem em ácidos biliares secundários; No cólon são reciclados através de circulação entero-hepática. O sequestro no cólon pode levar à formação de um complexo insolúvel e por causa disso interrompe a reabsorção, levando a um desvio do metabolismo hepático colesterol para a formação de ácidos biliares e uma resultante diminuição da concentração endógena de colesterol (STAELS et al., 2010).

\subsection{Regulação genética do transporte celular e da biossíntese do colesterol}

O extenso estudo dos cálculos biliares para fins terapêuticos possibilitou a descoberta do primeiro esterol conhecido, o colesterol. Inicialmente denominado de "cholesterine", sua fórmula correta levou mais 30 anos para estabelecer a exata representação espacial da molécula e uma das primeiras correlações entre o colesterol e a saúde humana foi relatada em 1843, com a visualização e confirmação da presença de colesterol organizado em placas nas artérias (POPJAK., 1986; NES, 2011).

A expressão de enzimas, proteínas sinalizadoras e transportadores de membrana refletem indiretamente os efeitos das alterações na expressão gênica relacionadas ao metabolismo do colesterol. A absorção do colesterol intestinal é mediada por transportadores de membrana, tais como Niemann-pick C1-like 1 (NPC1L1) e transportadores G5 e G8 (ABCG5/G8). A NPC1L1 é a principal proteína responsável pela absorção de colesterol micelar no lúmen. O colesterol da dieta é incorporado nos quilomícrons, que após serem metabolizados em quilomicrons remanescentes, são captados pelo fígado (TACHIBANA et al., 2007).

Em células animais, potencialmente todos os tecidos possuem a capacidade de produzir colesterol, como o intestino, os tecidos reprodutivos, o córtex adrenal, mas a produção majoritária se encontra no fígado pela síntese de novo de colesterol, denominada via do mevalonato (COSKUN et al., 2013). A biossíntese do colesterol compreende mais de 20 reações catalisadas enzimaticamente e ocorre em quatro etapas principais: 1) formação de mevalonato; 2) conversão de mevalonato à esqualeno; 3) ciclização de esqualeno formando núcleo esteroide 4) Formação da molécula de colesterol (MATHEW et al., 2011; COSKUN et al., 2013). Assim, o fígado desempenha um papel central na síntese de colesterol e na absorção/reabsorção de 
lipoproteínas ricas em colesterol, possibilitando a regulação da concentração plasmática de colesterol, tanto provenientes da dieta quanto pela produção endógena.

O passo limitante da velocidade da via do mevalonato é a conversão de 3-Hidroxi-3-metilglutaril coenzima A (HMG-CoA) em mevalonato catalisada pela 3-Hidroxi-3-metilglutaril coenzima A redutase (HMGCR). Os estudos de Brown e Goldstein (1997), mostraram que tanto a enzima quanto a LDLR são regulados e coordenados por fatores de transcrição denominados SREBPs (sterol regulatory element binding proteins), responsáveis por ativar os genes da HMGCR e LDLR. Essa via também é regulada por retroalimentação quando há ingestão dietética de colesterol e, em consequência disso, também pelos receptores de absorção plasmática de LDL. Quando esses dois componentes estão elevados, a HMGCR é inibida e a formação de mevalonato é interrompida. Complementarmente, o colesterol em excesso é desviado para a produção de outros derivados como ácidos biliares, vitamina $D$, hormônios esteroides, com o intuito de manter a homeostase (GOLDSTEIN e BROWN, 1990; IKONEN, 2008).

No fígado, dois fatores de transcrição, a proteína de ligação do elemento regulação do esterol 2 (SREBP2) e o Liver $X$ receptor alfa (LXR $\alpha)$ modulam a homeostase do colesterol intracelular. Estas proteínas são capazes de modular a expressão dos genes HMGCR e LDLR, inibindo ou ativando as enzimas de transcrição ou fosforilação. Especificamente, a ativação da proteína quinase ativada por adenosina monofosfato 1 (AMPK1) atua como um sensor de energia hepática limitando vias anabólicas e facilitando vias catabólicas (para aumentar a geração de ATP). A ativação da AMPK1 hepática conduz a uma diminuição da síntese de colesterol por falta de fósforo disponível para a fosforilação de HMGCR (VIOLLET et al., 2009).

O transporte reverso do colesterol é a via pela qual o colesterol nos tecidos periféricos é transferido através do plasma para o fígado. Este também pode ser reciclado ou excretado na bile e/ou utilizado como precursor para produção de hormônios. De forma antagônica aos anteriores, os transportadores de membrana ABCA1 e ABCG1 promovem o efluxo de células extra-hepáticas e a transferência de ésteres de colesterol ligados à apolipoproteína AI (ApoA-I) ou oxiesteróis para a molécula de $\mathrm{HDL}$, possibilitando o transporte reverso de colesterol para o fígado (KIDAMBI e PATEL, 2008). Esses transportadores são regulados de forma 
homeostática, expressos geneticamente segundo a necessidade ou não de colesterol nos diversos compartimentos e tecidos.

Em ratos alimentados com ração adicionada de proteínas de tremoço branco, observou-se redução substancial de lipídeos plasmáticos, sugerindo atividade hipocolesterolemizante similar à de outras proteínas de leguminosas. Entretanto nesse caso, a redução de colesterol foi associada à estimulação dos receptores de lipoproteína de baixa densidade (LDLR) demonstrado in vitro utilizando células HepG2 derivadas de hepatoma humano (SIRTORI et al., 2004).

No fígado de ratos alimentados com extratos de proteínas de tremoço, foi observada redução da expressão de genes envolvidos na síntese de colesterol, como o da hidroximetilglutaril coenzima A redutase (HMGCR), de triglicerídeos, da proteína de ligação ao elemento regulatório de esterol (SREBP) e do acido graxo sintase $(F A S)$. Resultados semelhantes foram encontrados para proteína de amaranto (BETTZIECHE et al., 2008; MENDONCA et al., 2009).

O feijão caupi é uma dicotiledônea que pertence à ordem Fabales, família Fabaceae, subfamília Faboideae, tribo Phaseoleae, subtribo Phaseolinea e ao gênero Vigna. Constituindo-se na principal cultura de subsistência das regiões Norte e Nordeste brasileiro e também é amplamente encontrado no continente africano, presente principalmente no hábito alimentar de famílias de baixa renda (Instituto Brasileiro De Geografia, 2002; Mousinho, 2005; Frota et al., 2010). As formas cultivadas no Brasil são conhecidas por várias denominações como: feijão de praia, feijão de rama, feijão fradinho, sendo os mais comuns, feijão macassar, feijão de corda ou caupi e feijão de metro (FREIRE FILHO et al., 1981; EMBRAPA, 1987; IBGE, 2002).

Frota et al. (2008) produziram isolado proteico de feijão caupi e verificaram a ação da proteína isolada no metabolismo lipídico de hamsters hipercolesterolemizados, provocando redução significativa no colesterol total $(20 \%)$ e colesterol não-HDL (22 \%) comparada à dieta controle com caseína.

Posteriormente, um shake contendo isolado proteico de feijão caupi foi administrado por Frota (2011) em humanos com hipercolesterolemia leve de modo a confirmar o estudo com hamsters. Como resultado,o consumo de $25 \mathrm{~g} / \mathrm{dia}$ de proteína de feijão caupi por indivíduo adulto hipercolesterolêmico, sem alterar estilo de vida, foi capaz de reduzir colesterol total, LDL colesterol, colesterol não-HDL e discreto aumento do HDL colesterol. 
Entretanto, a modulação da biossíntese e da absorção de colesterol após o consumo do isolado proteico do feijão caupi ainda não está totalmente esclarecido. Para entender esses mecanismos, a abordagem metodológica adotada neste estudo baseia-se em diversos relatos com modelos de linhagens celulares HepG2 e Caco-2 para esclarecer o transporte de colesterol e a relação com os peptídeos do feijão caupi (GENVIGIR, et al., 2011).

\section{OBJETIVO}

\subsection{Objetivo geral}

Investigar o transporte intestinal e avaliar o efeito nas vias luminal e endógena do metabolismo do colesterol de peptídeos provenientes de feijão caupi (Vigna unguiculata L. Walp).

\subsection{Objetivos específicos}

$\checkmark$ Identificar mudanças químicas e estruturais causadas pela fração $\leq 3 \mathrm{kDa}$ do hidrolisado e peptídeos do feijão caupi nas micelas de colesterol in vitro.

$\checkmark$ Avaliar o transporte celular dos peptídeos em cultura de células Caco-2;

$\checkmark$ Avaliar o efeito da fração $\leq 3 \mathrm{kDa}$ do hidrolisado na expressão dos genes NPC1L1, ABCA1 e ABCG1, nas células Caco-2;

$\checkmark$ Avaliar o efeito dos peptídeos permeáveis, na expressão dos genes SREBP2, LXRa AMPK1, HMGCR, e receptor de LDL (LDLR) em células HepG2. 


\section{MATERIAL E MÉTODOS}

\subsection{Obtenção da farinha do feijão caupi}

O feijão caupi (Vigna unguiculata L. Walp) cultivar BRS-Milênio, foi fornecido pela EMBRAPA transferência de tecnologia escritório de Petrolina, Pernambuco. Os grãos de feijão foram triturados e tamisados (peneira de 0,42 $\mathrm{mm}$ ), gerando a farinha de feijão que foi utilizada para o processo de isolamento de proteína.

\subsection{Preparação da proteína}

\subsubsection{Isolamento proteico das farinhas de feijão caupi}

Os grãos de feijão foram triturados, tamisados (peneira de 0,42 mm) e a farinha resultante foi desengordurada com hexano na proporção 1:6 m/v, secas em estufa a $60{ }^{\circ} \mathrm{C}$ e submetidas ao isolamento proteico de forma similar ao realizado em trabalhos anteriores realizados no Laboratório de Propriedades Funcionais de Alimentos da FSP/USP (MARQUES, 2013) por precipitação isoelétrica.

Após desengordurada, o pH da suspensão de 10\% da farinha de caupi em água foi ajustado com $\mathrm{NaOH} 1 \mathrm{M}$ e deixada por 2 horas sob agitação horizontal em pH 8,5. Posteriormente, a suspensão foi filtrada com auxílio de gaze e o resíduo descartado. Em seguida, o filtrado foi centrifugado e os precipitados removidos. Os sobrenadantes foram armazenados sob refrigeração $\left(4^{\circ} \mathrm{C}\right)$ durante $12 \mathrm{~h}$ em $\mathrm{pH} 4,5$, por adição de $\mathrm{HCl}$ $1 \mathrm{M}$. Após esta etapa, a suspensão foi novamente centrifugada e foi coletado a fração insolúvel (precipitado), que representa o isolado proteico de caupi.

O isolado de caupi foi novamente desengordurado pelo método de Bligh e Dyer (1959). Após desengordurar, o isolado proteico foi liofilizado, triturado em moinho e acondicionado.

\subsubsection{Digestão in vitro dos isolados proteicos}

A digestão dos isolados teve a intenção de simular a digestão gástrica e intestinal humana, segundo (Marques, 2013). Em solução de $2 \%$ de proteína em $\mathrm{NaCL} 30 \mathrm{mM}$ a $37^{\circ} \mathrm{C}, \mathrm{pH}=2$, adicionou-se pepsina (p7012 Sigma atividade $\geq 2500$ unidades $/ \mathrm{mg}$ proteína) enzima/substrato $1: 1000 \mathrm{~m} / \mathrm{m}$. A mistura foi deixada em incubação por 2 horas em banho-maria com agitação constante (modelo SW22 - 
JULABO). Após acertar o pH para $7 \mathrm{com} \mathrm{NaOH} 1 \mathrm{~N}$, houve subsequente adição de pancreatina (p-7545 atividade equivalente a $8 x$ U.S.P.) por mais 2 horas, totalizando 4 horas de digestão enzimática para se obter um hidrolisado com grau de hidrólise rica em peptídeos (SILVESTRE et al., 1994; BIASUTTI et al., 2008).

A reação foi interrompida com aquecimento de $80^{\circ} \mathrm{C}$ por 20 minutos e os hidrolisados submetidos à centrifugação a $9880 \times g$ por 20 minutos separando os sobrenadantes para as análises posteriores. Para isolar peptídeos de baixo peso molecular, o sobrenadante foi passado através de uma membrana de ultra filtração por centrifugação (5000 × g/50 min) em dispositivos Millipore AMICON de 3 kDa.

Os hidrolisados foram liofilizados e posteriormente foi realizada a quantificação de nitrogênio pelo método de determinação de proteínas 923.03 da AOAC (2010).

\subsubsection{Determinação do grau de hidrólise}

O grau de hidrólise foi quantificado como a solubilidade da proteína em ácido tricloroacético (TCA) de acordo com Hoyle e Merritt (Hoyle e Merritt, 1994). Este método baseia-se no uso do TCA para precipitar a proteína não hidrolisada que pode estar presente, admitindo que o nitrogênio quantificado no sobrenadante seja proveniente de aminoácidos e pequenos peptídeos (RUTHERFURD, 2010).

Uma alíquota de $10 \mathrm{~mL}$ de cada hidrolisado foi adicionada em $10 \%$ de TCA para solubilização e após 15 minutos em repouso, as replicatas foram centrifugadas a $10000 \times \mathrm{g}$ por $15 \mathrm{~min}$. $O$ teor proteico foi analisando no sobrenadante determinado pelo método de determinação de proteínas 923.03 da AOAC (2010).

As proteínas solúveis em TCA do hidrolisado, foram relacionadas de forma percentual às quantidades totais de proteína presente no isolado proteico, calculado de acordo com a seguinte equação:

$$
\% \mathrm{GH}=\frac{\text { P. hidrolisados }}{\text { Proteina total }} \times 100
$$

Onde:

\%GH: Percentual de grau de hidrólise

P. hidrolisado: quantidade de proteínas solúveis em TCA do hidrolisado;

Proteína total: quantidade de proteínas presentes no isolado proteico. 


\subsubsection{Eletroforese SDS-PAGE}

A eletroforese SDS-PAGE foi realizada de acordo com Laemmli (1970). O gel concentrador contendo $4 \%$ de acrilamida em tampão Tris-HCl pH 6,8 foi preparado sobre o gel de análise com $10 \%$ de acrilamida em tampão Tris- $\mathrm{HCl}$ pH 8,8. As proteínas foram extraídas com tampão contendo SDS, mercaptoetanol e uréia.

A eletroforese foi conduzida aplicando-se $50 \mu \mathrm{g}$ de proteína em cada poço. A amperagem foi fixada em $20 \mathrm{~mA}$ para cada gel de $1,0 \mathrm{~mm}$, voltagem auto-ajustável até o máximo de $300 \mathrm{~V}$. Após a corrida, os géis foram corados com Solução de Azul de Comassie R Brilhante 0,025\% em $40 \%$ de metanol e $7 \%$ de ácido acético, e descorados no mesmo solvente (metanol e ácido acético).

\subsection{VIA LUMINAL: mudanças químicas e estruturais nas micelas de colesterol}

De acordo com screening prévio feito no hidrolisado total da proteína do feijão caupi (MARQUES, FONTANARI, et al., 2015) os peptídeos Leu-Leu-Ans-Pro-Asp-Asp-Glu-Gln-Leu (LLNPDDEQL); Phe-Phe-Phe-GlyGln-Asp-Gly-Gly-Ser-Lys-Gly-Glu-Glu (FFFGQDGGSKGEE) e Leu-Asn-Leu (LNL) foram escolhidos, baseado numa predição in silico da atividade biológica (Tabela 1), e sintetizados (pureza > $95 \%$ ). Juntamente com a fração $\leq 3 \mathrm{kDa}$ do hidrolisado, os 3 peptídeos foram testados na interferência na solubilização de colesterol, tamanho das micelas de colesterol, interação com ácidos biliares, fosfatidilcolina e separação de cristais de colesterol in vitro.

Tabela 1:Screening de sequências peptídicas do hidrolisado de feijão caupi e sua potencial atividade biológica, propriedades físico-químicas e fonte proteica.

\begin{tabular}{|c|c|c|c|c|c|c|}
\hline $\begin{array}{r}P \\
\text { eptide } \\
0^{\mathrm{a}}\end{array}$ & $\begin{array}{c}\text { Peso } \\
\text { molecular } \\
\text { observado } \\
\text { /peso } \\
\text { molecular } \\
\text { teórico } \\
(\mathrm{Da})^{\mathrm{e}}\end{array}$ & $\begin{array}{l}\text { Possível atividade } \\
\text { biológica }^{b}\end{array}$ & $\begin{array}{l}\text { Razão de } \\
\text { hidrofobi } \\
\text { cidade } \\
(\%)^{c}\end{array}$ & $\begin{array}{l}\text { Ponto } \\
\text { Isoelétric } \\
0^{\mathrm{e}}\end{array}$ & $\begin{array}{l}\text { Carga a } \\
\mathrm{pH} 7^{\mathrm{e}}\end{array}$ & $\begin{array}{l}\text { Fonte de } \\
\text { proteína de }^{\text {Caupi }}{ }^{\mathrm{d}}\end{array}$ \\
\hline LSEGDL & $632,3 / 632,6$ & $\begin{array}{l}\text { Inibidor de ECA; } \\
\text { liberador de } \\
\text { substância bioativa }\end{array}$ & 33.3 & $\mathrm{pH} 3.01$ & -2 & Lectina \\
\hline FFGQDGAVV & $1256,5 / 125$ & & 53.84 & & & $\begin{array}{l}\text { Zeaxantina } \\
\text { epoxidase; }\end{array}$ \\
\hline
\end{tabular}




\begin{tabular}{|c|c|c|c|c|c|c|}
\hline AGSC & 7,3 & $\begin{array}{l}\text { Inibidor de ECA; } \\
\text { Inibidor de } \\
\text { neuropeptídeo; } \\
\text { inibidor de } \\
\text { dipeptidil- } \\
\text { aminopeptidase IV }\end{array}$ & & $\mathrm{pH} 3.1$ & -1 & $\begin{array}{l}\text { Glutatione } \\
\text { redutase }\end{array}$ \\
\hline LLNPDDEQL & $\begin{array}{c}1055,5 / 105 \\
6,1\end{array}$ & $\begin{array}{l}\text { Inibidor de ECA; } \\
\text { Inibidor de } \\
\text { dipeptidil- } \\
\text { aminopeptidase IV } \\
\text {; Peptídeo } \\
\text { estimulador de } \\
\text { captação de } \\
\text { glicose }\end{array}$ & 30.00 & pH 2.87 & -3 & $\begin{array}{c}\text { Acetil-CoA } \\
\text { carboxilase } \\
\text { carboxiltransfera } \\
\text { se; Fosfolipase } \\
\text { D alfa 1 }\end{array}$ \\
\hline MPTTSL & $648,3 / 648,7$ & $\begin{array}{l}\text { Inibidor de ECA; } \\
\text { Inibidor de } \\
\text { dipeptidil- } \\
\text { aminopeptidase IV; }\end{array}$ & 33.3 & pH 6.01 & 0 & $\begin{array}{c}\text { cloroplasto } \\
\text { hipotético RF34 }\end{array}$ \\
\hline GCLTLN & $619,2 / 619,7$ & Inibidor de ECA & 50.00 & pH 5.33 & 0 & $\begin{array}{l}\text { inibidor de } \\
\text { protease tipo } \\
\text { Kunitz }\end{array}$ \\
\hline GCTLN & $506,2 / 506,5$ & Inibidor de ECA & 40.00 & pH 5.33 & 0 & $\begin{array}{l}\text { Nenhuma } \\
\text { similaridade } \\
\text { encontrada }\end{array}$ \\
\hline & & $\begin{array}{l}\text { Peptídeo } \\
\text { estimulador de } \\
\text { captação de }\end{array}$ & & & & \\
\hline $\begin{array}{c}\text { LLDMKDNKG } \\
\mathrm{H}\end{array}$ & $\begin{array}{c}1169,5 / 117 \\
0,3\end{array}$ & $\begin{array}{l}\text { glicose; Inibidor de } \\
\text { ECA; Inibidor de } \\
\text { dipeptidil- } \\
\text { aminopeptidase IV; } \\
\text { Antioxidante. }\end{array}$ & 30.00 & pH 7.79 & 0.1 & $\begin{array}{l}\text { Inibidor de } \\
\text { protease tipo } \\
\text { Bowman-Birk }\end{array}$ \\
\hline KD & $261,1 / 261,2$ & Antioxidante & 0 & pH 6.75 & 0 & $\begin{array}{c}\text { Nenhuma } \\
\text { similaridade } \\
\text { encontrada }\end{array}$ \\
\hline LNL & $358,2 / 358,4$ & Inibidor de ECA & 66.66 & pH 6.01 & 0 & $\begin{array}{l}\text { Nenhuma } \\
\text { similaridade } \\
\text { encontrada }\end{array}$ \\
\hline LDSLT & $547,2 / 547,6$ & None & 40.00 & $\mathrm{pH} 3.1$ & -1 & Lectina \\
\hline $\begin{array}{c}\text { FFFGQDGGS } \\
\text { KGEE }\end{array}$ & $\begin{array}{c}1403,5 / 140 \\
4,4\end{array}$ & $\begin{array}{l}\text { Inibidor de ECA ; } \\
\text { liberador de } \\
\text { substância } \\
\text { vasoativa; Inibidor } \\
\text { de neuropeptídeo. }\end{array}$ & 23.07 & pH 3.83 & -2 & $\begin{array}{c}\text { Fosfolipase D } \\
\text { alfa 1; Proteína } \\
\text { de transferência } \\
\text { de lipídeo não } \\
\text { específica } \\
\text { AKCS9 }\end{array}$ \\
\hline
\end{tabular}

${ }^{\text {a }}$ Peptídeos com PEAKS ALC escore ode $50 \%$ ou mais

${ }^{\mathrm{b}}$ Determinado usando BIOPEP

${ }^{c}$ calculado como percentual de resíduos hidrofóbicos (I, V, L, F, C, M, A, W) na sequencia peptídica 


\footnotetext{
${ }^{\mathrm{d}}$ Determinado usando BLAST tool

e Determinado usando Innovagen's calculadora de propriedades de peptídeos.
}

Fonte: Marques, 2015a. (traduzido e adaptado)

\subsubsection{Preparação das micelas de colesterol}

Com o intuito de simular as micelas de colesterol formadas no intestino para posterior absorção, procedeu-se à preparação de micelas in vitro. As micelas foram preparadas de acordo com o método de Zhang et al. (2012). Os lipídeos (concentração final no tampão aquoso): $0,5 \mathrm{mM}$ colesterol (3ß-Hidroxi-5colesteno), $1 \mathrm{mM}$ 9-cis,12-cis-ácido linolênico $\left(\mathrm{CH}_{3}\left(\mathrm{CH}_{2}\right)_{4} \mathrm{CH}=\mathrm{CHCH}{ }_{2} \mathrm{CH}=\mathrm{CH}\left(\mathrm{CH}_{2}\right)_{7} \mathrm{C}\right.$ $\mathrm{O}_{2} \mathrm{H}$ ) and 2,4 mM fosfatidilcolina de ovo (1,2-Diacil-sn-glicero-3-fosfocolina) foi dissolvido em metanol e adicionado em tubos de $2 \mathrm{~mL}$ e seco com nitrogênio. Dessa forma a razão [fosfatidilcolina]/([fosfatidilcolina] + [ácidos biliares]) foi de 0,26. $\mathrm{Na}$ mistura seca de lipídeos foi adicionada $500 \mu \mathrm{L}$ de $15 \mathrm{mM}$ de tampão fosfato de sódio monobásico contendo 6,6 mM de taurocolato de sódio $\left(\mathrm{C}_{26} \mathrm{H}_{44} \mathrm{NNaO}_{7} \mathrm{~S}\right)$ e $132 \mathrm{mM}$ de $\mathrm{NaCL}$ à $\mathrm{pH} 7,4$. Todos os reagentes foram adquiridos da empresa SIGMAALDRICH®. A suspensão foi submetida à ultrassom em banho com gelo por $15 \mathrm{~min} e$ incubado posteriormente $30 \mathrm{~min}$ à $37^{\circ} \mathrm{C}$ para formar micelas. Todas as análises realizadas com as micelas de colesterol foram realizadas após 2 dias para estabilização do sistema.

\subsubsection{Espectroscopia de fluorescência: confirmação da formação de micelas e mudanças na composição micelar.}

A espectroscopia de fluorescência nas micelas foi realizada de acordo com Greenspan and Fowler (1985) para investigar o efeito da fração $\leq 3 \mathrm{kDa}$ do hidrolisado e dos peptídeos na internalização de colesterol e mudanças estruturais. $\mathrm{O}$ volume de $0,83 \mu \mathrm{L}$ do ligante hidrofóbico vermelho do nilovermelho do nilo (9-dietilamino-5H-benzo[a]fenoxazine-5-ona) $0,1 \mathrm{mg} / \mathrm{mL}$ em acetona foi adicionado à $0,5 \mathrm{~mL}$ da solução micelar. $\mathrm{O}$ espectro da emissão de fluorescência foi medido a $25^{\circ} \mathrm{C}$ na faixa de 575 a $700 \mathrm{~nm}$, excitação em $549 \mathrm{~nm}$ usando Varian® Cary Eclypse fluorimeter equipado com lâmpada xenon. A fluorescência normalizada foi obtida após subtração do espectro da solução tampão (branco). 


\subsubsection{Ensaio de solubilização micelar de colesterol}

Para se verificar o efeito na solubilidade de colesterol, a fração $\leq 3 \mathrm{kDa}$ do hidrolisado e/ou peptídeos foram adicionados à micelas prontas e depois a mistura foi submetida à ultrassom de bancada (Transsonic Digital S Elma) por 1 min e incubado por $1 \mathrm{~h}$ à $37^{\circ} \mathrm{C}$. A solução foi posteriormente centrifugada à $1000 \mathrm{xg}$ for $10 \mathrm{~min} \mathrm{e}$ filtrada através de filtro 0,20 $\mu \mathrm{m}$ Millex-GP filter (Millipore, Bedford, MA, USA).

Coletou-se $50 \mu \mathrm{l}$ do sobrenadante para determinar as concentrações de colesterol utilizando o Kit de ensaio de colesterol do Amplex ® red (invitrogen, Paisley, Reino Unido) por meio de fluorescência usando excitação em $555 \mathrm{~nm}$ e emissão da detecção em $590 \mathrm{~nm}$, realizado em leitor de placas SpectraMax M5 (molecular devices, Sunnyvale, CA, EUA) de acordo com instruções do fabricante. As concentrações de colesterol foram determinadas a partir da curva padrão de calibração de colesterol. A capacidade de inibição foi calculada utilizando a seguinte equação:

Capacidade de inibição $(\%)=[(C o-C s) / C o] \times 100$

Onde: Co é a concentração de colesterol das micelas originais e Cs é a concentração de colesterol das micelas com hidrolisados.

\subsubsection{Mudança no tamanho das micelas de colesterol: espalhamento dinâmico de luz (Dynamic Light Scattering).}

O tamanho das micelas foi medido por espalhamento dinâmico de luz (Dynamic Light Scattering/DLS). Os experimentos foram conduzidos no equipamento ALV/CGS3 MD-4 compact goniometer system equipado com Multiple Tau digital real time correlator (ALV-7004) e um laser estado sólido ( $\lambda=532 \mathrm{~nm} ; 40 \mathrm{~mW}$ ). O experimento de varredura cobriu os ângulos de 60 a $120^{\circ}$ e leituras medias de $3 \times 20$ segundos à $20^{\circ} \mathrm{C}$. Como controle, o tampão de fosfato monobásico de sódio contendo $6,6 \mathrm{mM}$ de taurocolato de sódio e $132 \mathrm{mM}$ de $\mathrm{NaCl}$ à $\mathrm{pH} 7,4$ foi também avaliado e a formação espontânea de micelas não foi observado. 


\subsubsection{Interação com a fosfatidilcolina micelar}

Com o intuito de avaliar a capacidade da fração $\leq 3 \mathrm{kDa}$ do hidrolisado e dos peptídeos de solubilizar a fosfatidilcolina, diferentes concentrações de hidrolisado e peptídeos foram adicionados às soluções micelares. Após formação das micelas a mistura foi incubada durante $1 \mathrm{~h}$ a $37^{\circ} \mathrm{C}$ e, em seguida, centrifugado a $25000 \mathrm{xg}$ durante $1 \mathrm{~h}$. O sobrenadante foi filtrado através de um filtro de 0,2 $\mu \mathrm{m}$ (Millipore, Bedford, MA, USA) e os fosfolípideos do filtrado foram quantificados colorimetricamente com auxílio do kit Phospholipid Assay Kit ( $\mathrm{n}^{\circ}$ cat. MAK122, SIGMA-ALDRICH) de acordo com as recomendações do fabricante (KOBAYASHI et al., 2014). Esse método baseia-se na hidrólise enzimática da fração colina presente nos fosfolipídeos e na sua posterior detecção espectrofotométrica a $570 \mathrm{~nm}$, comparada à curva padrão de fosfatidilcolina em diluições seriadas.

\subsubsection{Ligação do hidrolisado e peptídeos com ácidos biliares}

A interação dos hidrolisados e peptídeos com os ácidos biliares da estrutura micelar foi avaliada de acordo com Yoshie-Stark e Wasche (YOSHIE-STARK e WASCHE, 2004). Diferentes concentrações da fração $\leq 3 \mathrm{kDa}$ do hidrolisado e dos peptídeos foram adicionados em solução tampão fosfato $(0,1 \mathrm{M})$ contendo $2 \mathrm{mM}$ de taurocolato de sódio $\left(\mathrm{C}_{26} \mathrm{H}_{44} \mathrm{NNaO}_{7} \mathrm{~S}\right)$ à $\mathrm{pH} 7,0$. Após incubação à $37^{\circ} \mathrm{C}$ durante $2 \mathrm{~h}$, cada amostra foi centrifugada e o sobrenadante foi reservado em frasco volumétrico. O precipitado foi ressuspendido em $1 \mathrm{~mL}$ de tampão fosfato $0,1 \mathrm{M} \mathrm{pH} \mathrm{7,0} \mathrm{misturou-se}$ bem e centrifugou-se novamente. O sobrenadante foi coletado e combinado com 0 sobrenadante anterior. Este procedimento foi repetido e em seguida foi quantificada a concentração de ácidos biliares espectrofotometricamente a $405 \mathrm{~nm}$ utilizando o kit Total Bile Acids Assay kit (Diazyme, Poway, CA, USA) a partir de uma curva padrão de ácido cólico.

Este método é baseado na oxidação enzimática de primeira ordem dos ácidos biliares à 3-cetoesteróides com formação de Tio-NADH. $50 \mathrm{mg} / \mathrm{mL}$ de resina colestiramina (SIGMA-ALDRICH), uma droga que se liga ao ácido biliar e reduz o colesterol. A colestiramina também foi avaliada quanto à sua capacidade de ligar ácidos biliares e utilizada como controle positivo. A capacidade de ligação de ácidos 
biliares foi dada como $\mu \mathrm{mol}$ de ácidos biliares ligado por grama de amostra (isto é, retida no precipitado após centrifugação).

\subsubsection{Separação e quantificação da fração de cristais de colesterol}

Com o intuito de avaliar a formação de cristais de colesterol após adição da fração $\leq 3 \mathrm{kDa}$ do hidrolisado e dos peptídeos, as micelas de colesterol foram submetidas à centrifugação 10 minutos após a adição de deoxicolato de sódio em quantidades suficientes para dessaturar o sistema modelo (índice de saturação de colesterol <1) (Moschetta et al., 2001). A concentração mínima de deoxicolato determinada previamente foi de $197 \mathrm{mM}$ baseada na concentração intermicelar de sais biliares (IMC) (MOSCHETTA et al., 2000) cruzado com os valores tabelados para determinar o índice de saturação de colesterol (CAREY, 1978).

O volume de $2 \mathrm{~mL}$ da solução de taurocolato a $197 \mathrm{mM}$ foi adicionado no filtro de $300 \mathrm{kDa}$ (Centrisart, Sartorius) e centrifugado à $500 \mathrm{xg}$ por $5 \mathrm{~min}$. Os resíduos foram retirados com auxílio de seringa cuidadosamente e descartados. Cada solução micelar foi submetida à ultracentrifugação de $50.000 \times \mathrm{g}$ à $37^{\circ} \mathrm{C}$ por $30 \mathrm{~min}$. $\mathrm{O}$ sobrenadante foi reservado. $O$ sobrenadante reservado das micelas de colesterol foi adicionado na parte superior do dispositivo e submetido à filtração gravitacional durante $1 \mathrm{~h}$. A massa de colesterol em forma de cristais foi determinada no filtrado após utilizando o Kit comercial de ensaio de colesterol Amplex ${ }^{\circledR}$ red (invitrogen, Paisley, Reino Unido).

\subsection{VIA ENDÓGENA DO COLESTEROL: permeação celular, expressão gênica de transportadores e da biossíntese do colesterol.}

\subsubsection{Condições de cultivo de linhagens Caco-2 e HepG2}

A linhagem celular Caco-2 é oriunda de um adenocarcinoma de cólon humano e atualmente é modelo celular mais empregado para investigar os processos de absorção intestinal in vitro. A linhagem Hep-G2, derivada do hepatoblastoma humano, manifesta muitas das funções atribuídas a um hepatócito de um ser humano normal e é constantemente utilizada para examinar o efeito de compostos alimentícios e fármacos na expressão de enzimas intra e extra-hepáticas relacionadas ao metabolismo colesterol (COHEN et al., 1984; ERICKSON e FIELDING, 1986; 
CONSONNI et al., 2010). As células Caco-2 e HepG2 foram mantidas em meio DMEM (Modified Dulbecco Eagle Médium) com alta concentração de glicose 4,5 g/L, suplementado com $10 \%$ de soro fetal bovino, $2 \mathrm{mM}$ de glutamina, $44 \mathrm{mM}$ de bicarbonato de sódio, $10000 \mathrm{UI} / \mathrm{mL}$ de estreptomicina e $10.000 \mathrm{UI} / \mathrm{mL}$ de penicilina. As células foram incubadas a $37^{\circ} \mathrm{C}$ numa atmosfera umidificada, contendo $5 \%$ de $\mathrm{CO}_{2}$. O meio de cultura foi substituído duas vezes por semana e as células foram tripsinizadas e repicadas a cada 2 dias (GENVIGIR et al., 2010). Para o subcultivo, as células foram transferidas para placas de 12 poços de poliestireno de área de $3,8 \mathrm{~cm}^{2}$, com densidade de $5 \times 10^{4}$ células $/ \mathrm{cm}^{2}$.

\subsubsection{Ensaio de citotoxicidade}

Para os experimentos de citotoxicidade, cada linhagem foi transferida para placas de 12 poços de poliestireno de área de $3,8 \mathrm{~cm}^{2}$, com densidade de $5 \times 10^{4}$ células $/ \mathrm{cm}^{2}$. As células Caco-2 foram então estimuladas com exposição ao hidrolisado proteico diluído do meio de cultura nas concentrações de $5 \mathrm{mg} / \mathrm{mL}$ e $10 \mathrm{mg} / \mathrm{mL}$ de nitrogênio para avaliar a citotoxidade do hidrolisado $\leq 3 \mathrm{kDa}$. As células HepG2 foram estimuladas com exposição aos peptídeos sintéticos diluídos do meio de cultura nas concentrações de $100 \mu \mathrm{M}$ e $250 \mu \mathrm{M}$ por $6 \mathrm{~h}$ e $24 \mathrm{~h}$ para avaliar a citotoxidade dos peptídeos.

Depois de incubadas nas concentrações e tempos acima, o sobrenadante de cada poço foi analisado usando o kit CytoTox® 96 Non-Radioactive Cytotoxicity Assay (Promega, Madison, WI) e a absorbância à $490 \mathrm{~nm}$ foi medida para determinar a liberação de lactato desidrogenase $(\mathrm{LDH})$ de acordo com as recomendações do fabricante.

\subsubsection{Ensaio de permeação celular através da monocamada de células Caco-2}

Para os experimentos de permeabilidade, as células foram transferidas para placas Transwell ${ }^{\circledR}$ contendo 12 poços com suporte de policarbonato de 0,4 $\mu \mathrm{m}$ de poro e área de $4,72 \mathrm{~cm}^{2}$, com densidade de $5 \times 10^{4}$ células $/ \mathrm{cm}^{2}$. Esperou-se a diferenciação das células por no mínimo 21 dias antes do experimento. As medidas de resistência elétrica transepitelial (TERR) foi realizada com auxílio do MIlicell-ERS 
Eletctrical Resistance System (Millipore, Bredford, MA, USA). As células foram mantidas em cultura, sendo utilizada monocamada com resistência maior que $200 \Omega . \mathrm{cm}^{-2}$. Foram utilizadas células entre os repiques de passagem 20 a 60.

Durante o ensaio de permeação, foi aplicado o hidrolisado diluído em tampão Hank's com 3 concentrações diferentes de hidrolisado $(0,5,2,5$ e $5 \mathrm{mg} / \mathrm{mL}$ de proteína). Após $2 \mathrm{~h}$ de incubação, o volume do compartimento inferior (totalizando 10) apenas da concentração de $5 \mathrm{mg} / \mathrm{mL}$ da câmara foi aspirado, liofilizado e ressuspendido em $1 \mathrm{~mL}$ de TFA $1 \%$ para análise qualitativa do permeato por LC/MS/MS. Os dados do perfil de peptídeos nos dois compartimentos foram utilizados para estimar a capacidade de permeação dos peptídeos em cultura celular (YUN et al., 2004).

Separadamente para ensaios de expressão de RNAm, as células Caco-2 foram estimuladas com hidrolisado proteico $\leq 3 \mathrm{kDa}$ em placas de 12 poços de poliestireno de área de $3,8 \mathrm{~cm}^{2}$, com densidade de $5 \times 10^{4}$ células $/ \mathrm{cm}^{2}$. Para isso, diluído no meio de cultura foi aplicado o hidrolisado nas mesmas 3 concentrações de hidrolisado $(0,5$, 2,5 e $5 \mathrm{mg} / \mathrm{mL}$ de proteína), nesse caso, incubados por $2 \mathrm{~h}$. Posteriormente, procedeu-se à extração de RNA total.

\subsubsection{Sequenciamento "de novo" de peptídeos permeados através das células}

\section{Caco-2}

O volume de $1,5 \mathrm{~mL}$ de permeato em tampão hanks (fração inferior coletada) e depois de acidificado com $0,1 \%$ de TFA (ácido trifluoroacético) foi submetido a uma extração de fase sólida utilizando cartucho Sep-Pak C18 (Waters, Milford, MA, USA). O cartucho foi equilibrado com $5 \mathrm{~mL}$ de $0,1 \%$ de TFA em acetonitrila/água 65:35 (solução B) e posteriormente com $10 \mathrm{~mL}$ de solução de $0,1 \%$ de TFA em acetonitrila/água 2:98 (solução A). A eluição dos peptídeos foi feita com a solução A, seca no equipamento centrivap $\mathrm{LABCONCO}^{\circledR}$ e ressuspendida em $500 \mu \mathrm{L}$ de $0,1 \%$ de TFA. Os permeato purificado foi mantido congelados $-20^{\circ} \mathrm{C}$ até o sequenciamento (MENIN et al., 2008).

O permeato foi colocado em placas de 96 poços do SIL-20A auto-sampler para análise de LC-MS em um espectrômetro de massas do tipo IT-TOF (Shimadzu). $20 \mu \mathrm{L}$ em alíquota da amostra foram injetadas e submetidas à RP-HPLC (20A Prominence system) coluna Discovery C18 1,5 (2 x 50 mm) utilizando como solvente $0.5 \%$ ácido 
fórmico (FA) (A) e acetonitrila $90 \%$, contendo 0,5\% FA (B) em gradiente linear de B para $A$ de 0 a $100 \%$ em 15 minutos, sobre fluxo constante de 0,2 mL. $\mathrm{min}^{-1}$. O controle dos instrumentos, aquisição de dados e processamento foi realizado com o software LCMS Solution suite (Shimadzu). O software PEAKS studio 7.0 (Ma et al., 2003) foi utilizado para sequenciamento de novo dos peptídeos bem como para fazer análises proteômicas em base de dados públicas. Todos os parâmetros do MS/MS foram manualmente revisados para correção, bem como a qualidade dos espectros.

Dois peptídeos foram sintetizados (Aminotech pesquisa e desenvolvimento, Diadema, SP, Brasil. Pureza > 95 \% sem modificações), variando apenas na ordem do resíduo C-terminal (HS e SH) como consequência da incerteza do sequenciamento 'de novo' apenas para essa porção do peptídeo. Contudo, o efeito biológico foi demonstrado apenas pelo análogo MELNAVSVV $\underline{\text { HS }}$ (APÊNDICE A).

\subsubsection{Abordagem “In Silico" para predição de bioatividade das sequencias peptídicas}

A proteína de origem dos peptídeos foi confirmada utilizando ferramenta BLAST®. A atividade biológica potencial dos peptideos foi prevista usando a base de dados BIOPEP (http://www.uwm.edu.pl/biochemia) e as propriedades físico-químicas foram preditas utilizando a ferramenta Innovagen's peptide property calculator (http://www.innovagen.se/custom-peptide-synthesis/peptide-property-lculator/peptideproperty-calculator.asp). Com o intuito de responder a probabilidade de peptídeos serem capazes de penetração celular, foi utilizado a ferramenta CPPperd (http://bioware.ucd.ie/ compass/biowareweb/Server_pages/cppp red.php). Uma pontuação acima de 0,5 sugere que o peptídeo é capaz de penetrar células (HOLTON et al., 2013).

\subsubsection{Tratamento das células HepG2 com análogos sintéticos identificados no compartimento basolateral da monocamada de Caco-2}

Os análogos sintéticos dos peptídeos identificados após permeação celular (MELNAVSVVHS e MELNAVSVVSH) foram aplicados individualmente em placa de 12 poços de poliestireno de área de $3,8 \mathrm{~cm}^{2}$, com densidade de $5 \times 10^{4}$ células $/ \mathrm{cm}^{2}$. 
Diluídos no meio de cultura, na concentração de $50 \mu \mathrm{M}$ e $100 \mu \mathrm{M}$, os peptídeos foram incubados durante $6 \mathrm{~h}$ ou $24 \mathrm{~h}$ e posteriormente procedeu-se à extração de RNA total (MEHTIEV et al., 2010).

\subsubsection{Análise da expressão gênica por qPCR em tempo real}

Alíquotas das células Caco-2 e HepG2 incubadas com os hidrolisados foram obtidos para extração do RNA total, utilizando o conjunto de reagentes miRNeasy mini Kit (Qiagen, Germantown, MD, USA) seguindo as indicações do fornecedor.

O rendimento do RNA total foi avaliado por espectrofotometria no ultravioleta (UV) utilizando-se o espectrofotômetro NanoDrop ® (NanoDrop Technologies INC., Wilmington, DE, EUA) e o grau de pureza do RNA determinado pela relação A260nm/A280nm.

A expressão do RNA mensageiro (RNAm) dos genes NPC1L1, ABCA1 e ABCG1, em células Caco-2 e HMGCR, AMPK1, LDLR, SREBP2 e LXR em células HepG2 foi realizada por reação de transcrição reversa seguida de amplificação por PCR em tempo real, por procedimento previamente descrito por GENVIGIR et al. (2011) e normalizados com o gene HRPT1.

O cDNA foi gerado a partir de $1 \mu \mathrm{g}$ de RNA, utilizando-se $200 \mathrm{ng}$ de iniciadores aleatórios (random primers) (Invitrogen Corporation, Carlsbad, CA, EUA), DTT 10 mmoles/L (Invitrogen Corporation, Carlsbad, CA, EUA), dNTPs $500 \mu \mathrm{M}$ (GE Healthcare, Amersham Biosciences do Brasil, São Paulo, SP), $200 \mathrm{U}$ de transcriptase reversa (RT) (SuperScriptTM II RT RNase H-) e tampão de RT [Tris-HCl 250 mM (pH 8,3), $\mathrm{KCl} 375 \mathrm{mM}, \mathrm{MgCl}_{2}$ 15mM] (Invitrogen Corporation, Carlsbad, CA, EUA). O ensaio de transcrição reversa foi realizado em termociclador PTC-200 (MJ Resarch Inc., Walthan, MA, EUA) com as seguintes etapas: $25^{\circ} \mathrm{C}$ por $10 \mathrm{~min}, 42^{\circ} \mathrm{C}$ por $50 \mathrm{~min}$ e $70 \stackrel{\circ}{C}$ por 15 min. $O$ cDNA obtido foi armazenado a $-30{ }^{\circ} \mathrm{C}$ até a realização do PCR.

A medida quantitativa da expressão do RNAm dos genes estudados foi realizada por PCR em tempo real utilizando o sistema de amplificação TaqMan® RTPCR (Applied Biosystems, Foster City, CA, EUA) utilizando-se o equipamento ABI Prism 7500 FAST (Applied Biosystems, Foster City, CA, EUA). A análise da expressão gênica foi realizada por método de quantificação relativa. Com a finalidade de escolher o gene endógeno mais adequado para o modelo, vários genes foram 
testados e analisados no programa GeNorm (Vandesompele et al., 2002). Os iniciadores e as sondas marcadas com fluoróforo validados foram fornecidos em solução 20 vezes concentrada pelo serviço "Assay by design" e/ou "Assay on demand" (Applied Biosystems, Foster City, CA, EUA). Os ensaios Hs00203602_m1 (NPC1L1), Hs00245154_m1 (ABCG1), Hs01059118_m1 (ABCA1), Hs00168352_m1

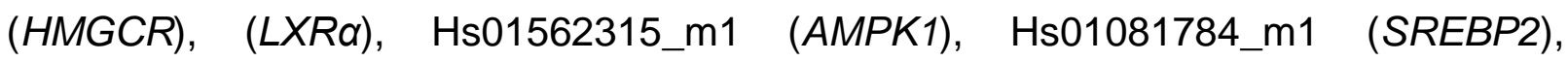
Hs00181192_m1 (LDLR) foram utilizados nesse estudo.

As análises de quantificação relativa da expressão de RNAm dos genes estudados foram realizadas utilizando o método do $\Delta \mathrm{Ct}$, com base na fórmula $2^{-\Delta \Delta \mathrm{Ct}}$. (Livak e Schmittgen, 2001). Previamente, foram calculadas as eficiências de todos os ensaios, sendo considerados adequados valores entre 90 e $110 \%$.

Com a finalidade de monitorar a precisão dos resultados das reações de amplificação realizadas por RT-PCR, as amostras foram analisadas em quadruplicata. 
Figura 4: Fluxograma geral dos experimentos.

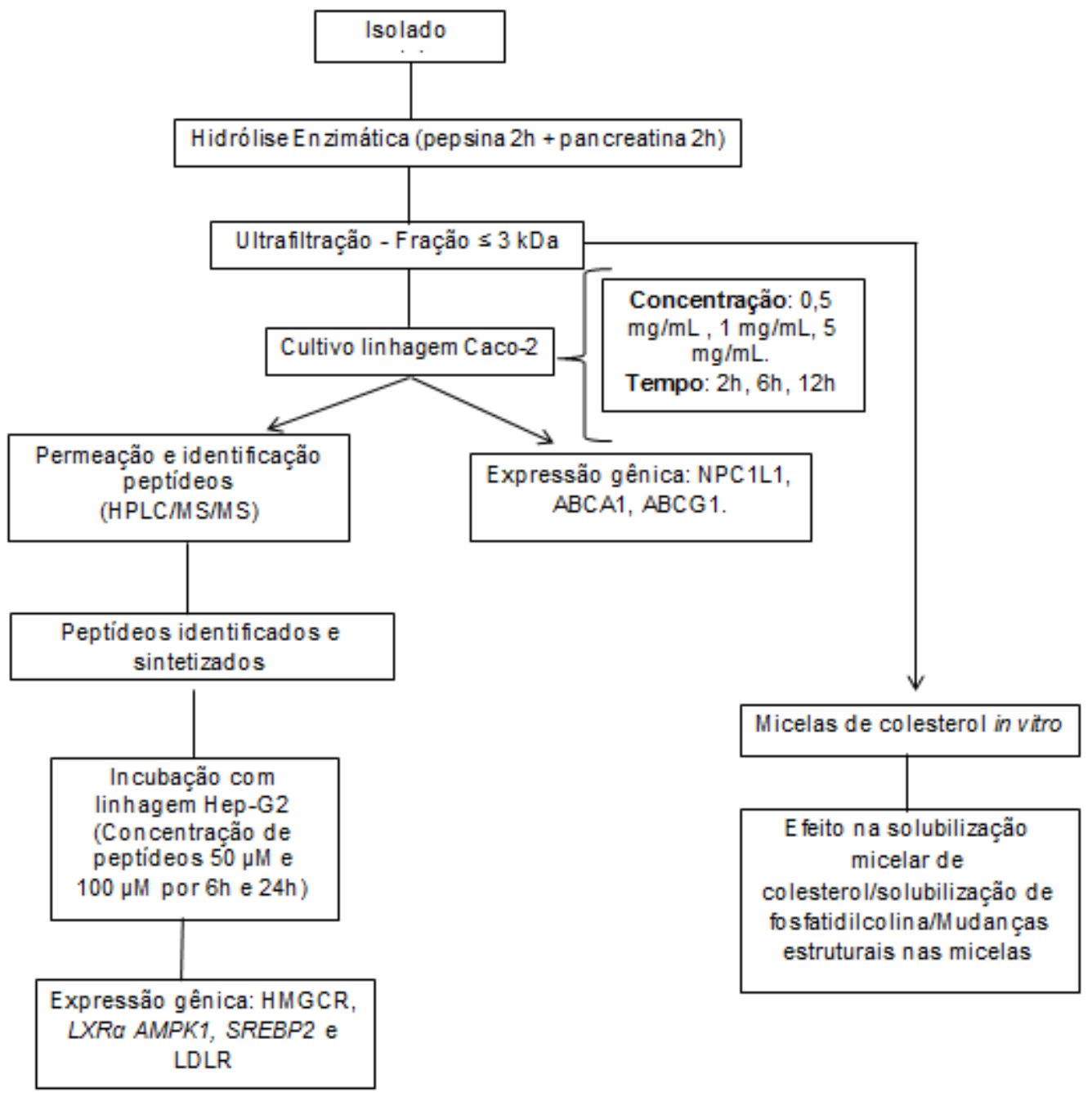

Fonte: Marques, M.R. (2017).

\subsection{Tratamento estatístico}

A escolha do gene endógeno foi analisado no programa GeNorm (Vandesompele et al., 2002). Os dados obtidos foram submetidos ao Teste $t$-Student ou à análise de variância (ANOVA two way), com auxílio do software Graphpad Prism 5 adotando-se o nível de significância de $p<0,05$. As diferenças entre as médias dos resultados em triplicata foram determinadas pelo teste de Bonferroni. 


\section{Resultados e discussão}

\subsection{Caracterização da proteína e da fração $\leq 3 \mathrm{kDa}$ do hidrolisado de feijão caupi}

O isolado proteico contendo $89,11 \pm 0,97 \%$ de proteína (em base seca) e grau de hidrólise de 37,13 \pm 1,05 \% foi usado como materia prima para produção da fração $\leq 3 \mathrm{kDa}$ do hidrolisado. Após submeter o isolado proteico à hidrólise enzimática e ultrafiltração, a fração $\leq 3 \mathrm{kDa}$ do hidrolisado obteve 73,87 $\pm 2,49 \%$ em proteína (base seca) e foi avaliado quanto a sua permeabilidade e expressão gênica nas células Caco-2.

A Figura 5 mostra a eletroforese de SDS-PAGE como uma visão geral da degradação da proteína do caupi (Vigna unguiculata L. Walp, BRS- Milênio) em diferentes passos até a produção da fração $\leq 3 \mathrm{kDa}$ do hidrolisado. A normalização dos procedimentos da hidrólise é altamente importante para a produção de peptídeos. $\mathrm{Na}$ literatura, existe uma forte relação entre o grau de hidrólise, pureza da proteína, a eficiência da hidrólise, as enzimas utilizadas durante o processo, com diferentes espécies de peptídeos formados. Em batatas, peptídeos produzidos por diferentes métodologias também foram responsáveis por efeitos diferentes sobre a capacidade hipocolesterolêmica (LIYANAGE et al., 2010). 
Figura 5: Eletroforese SDS-PAGE com gel $10 \%$ e $50 \mu \mathrm{g}$ em proteína de feijão caupi: 1- marcador de peso molecular, 2-Farinha integral, 3 - farinha desengordurada; 4 - isolado proteico, 5 - hidrolisado, 6 - fração $\leq 3 \mathrm{kDa}$ do hidrolisado.

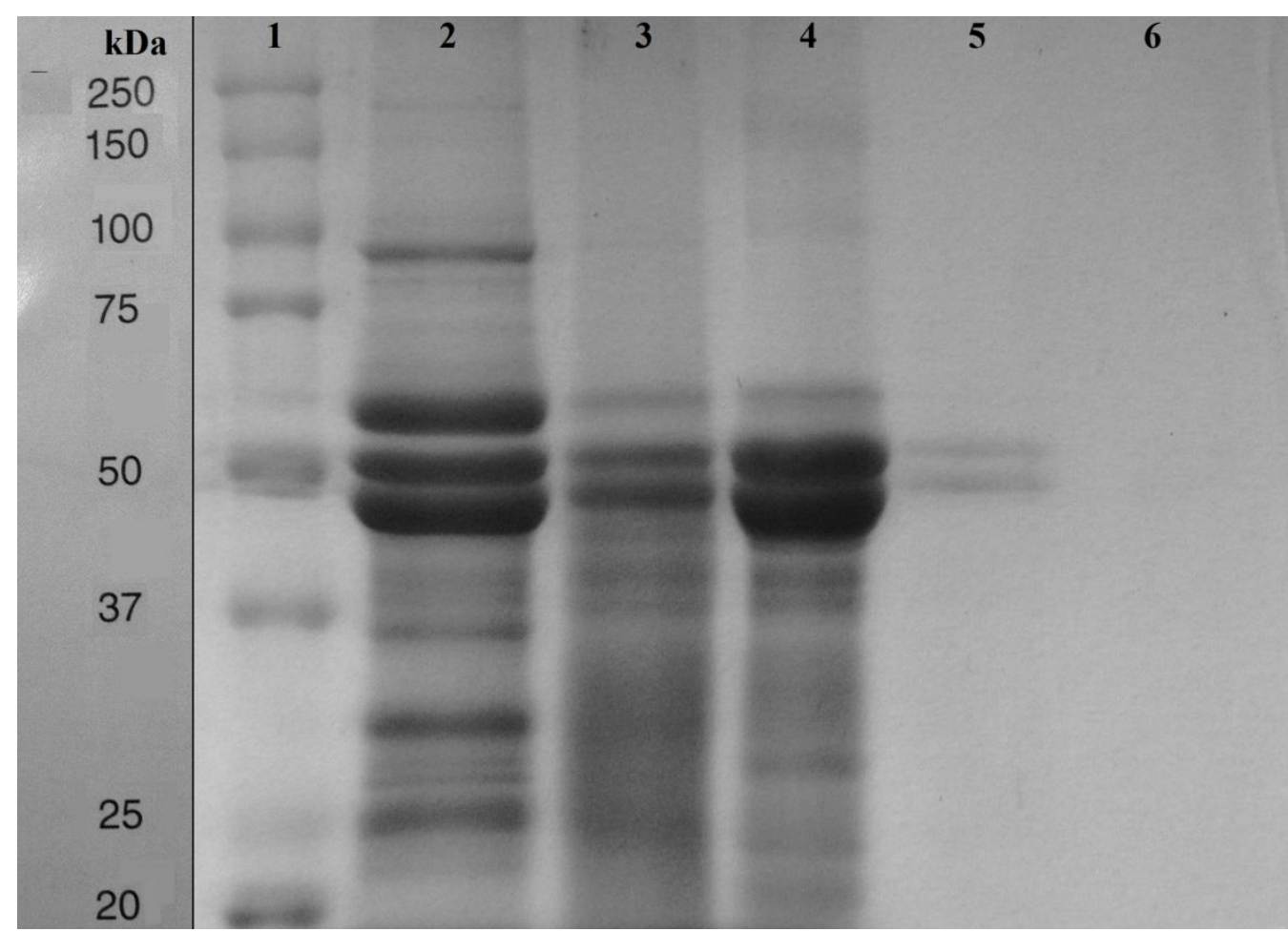

Fonte: Marques, M.R. (2017).

As proteínas do feijão caupi consistem em sua maioria por globulinas (denomidadas também de vicilinas, globulinas 7S ou $\beta$-vignina), seguido de albuminas, glutelinas e prolaminas (Gonçalves et al., 2016). As globulinas representam $80 \%$ do total de proteínas no caupi; são formadas por duas cadeias polipeptídeo com peso molecular de 56 e $52 \mathrm{kDa}$ e aparecem em maior destaque no gel. Como pode ser visto a partir da Figura 5, o fração $\leq 3 \mathrm{kDa}$ do hidrolisado demonstrou a ação das enzimas proteolíticas e do processo de ultrafiltração, pois se prentedia obter apenas frações peptídicas.

\subsection{VIA LUMINAL: mudanças químicas e estruturais nas micelas de colesterol}

\subsubsection{Confirmação da formação de micelas e mudanças no tamanho micelar}

Com o objetivo de confirmar a formação de micelas e uma possível mudança na composição micelar após adição dos peptídeos do caupi, foi realizada uma 
varredura espectroscópica de fluorescência. Para testar esta hipótese, adicionou-se o ligante vermelho do nilo às soluções micelares na presença e na ausêcia dos compostos de interesse. Nas Figuras 5 e 6 é possível notar que os picos do espectro de emissão mudaram de $641 \mathrm{~nm}$ para 628,9 nm confirmando a formação de um ambiente hidrofóbico na solução micelar padrão, atestando a internalização do colesterol. A Figura 6 mostra a redução na itensidade de fluorescência quando adicionada a fração $\leq 3 \mathrm{kDa}$ do hidrolisado no meio.

Figura 6: Espectro de emissão de fluorescência do vermelho do nilovermelho do nilo na presença da fração $\leq 3 \mathrm{kDa}$ do hidrolisado. O tampão também contém taurocolato de sódio.

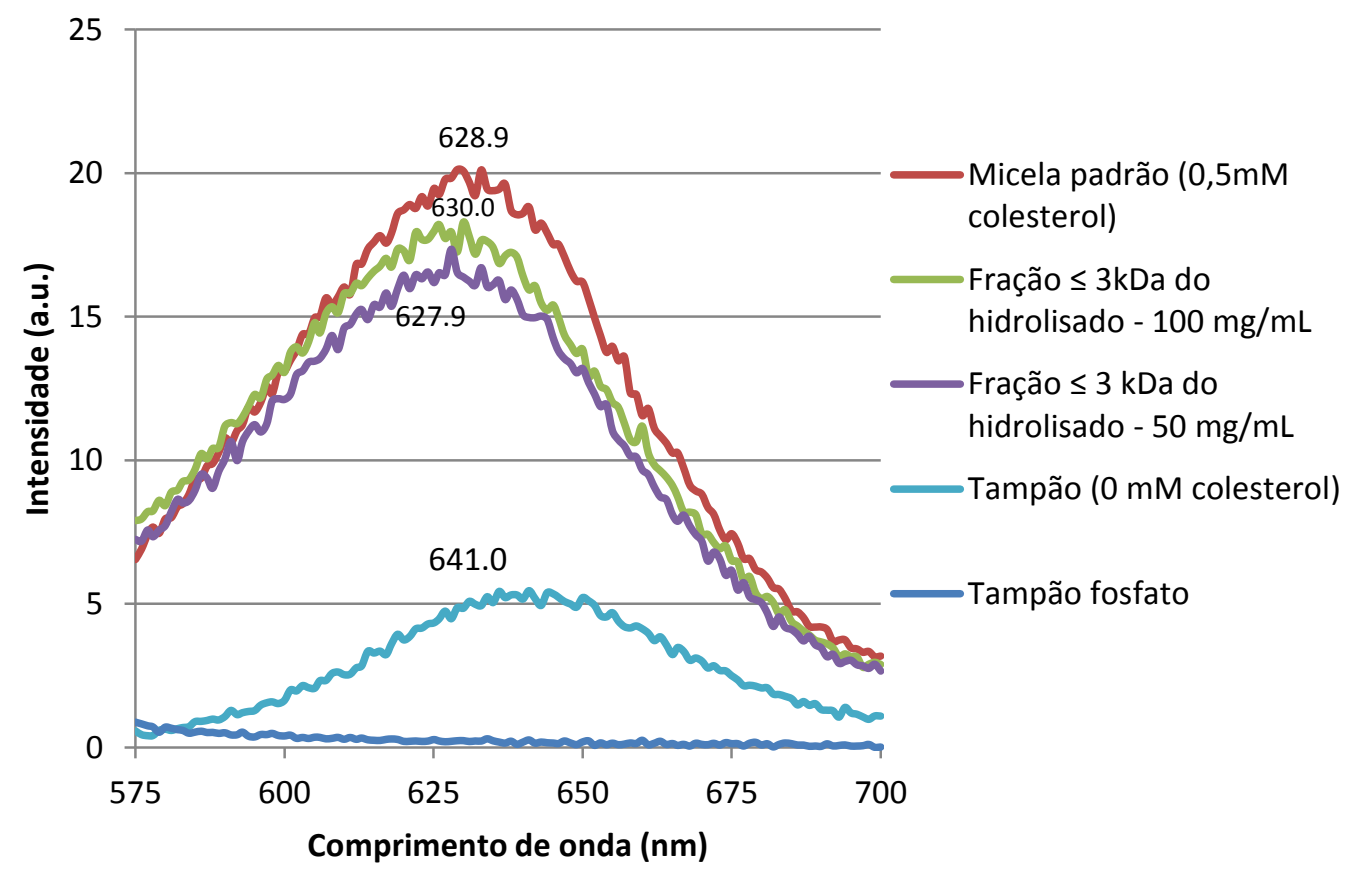

Fonte: Marques, M.R. (2017). 
Figura 7: Espectro de emissão de fluorescência do vermelho do nilovermelho do nilo na presença de $1000 \mu \mathrm{g} / \mathrm{mL}$ de cada peptídeo encontrado no hidrolisado total. O tampão também contém taurocolato de sódio.

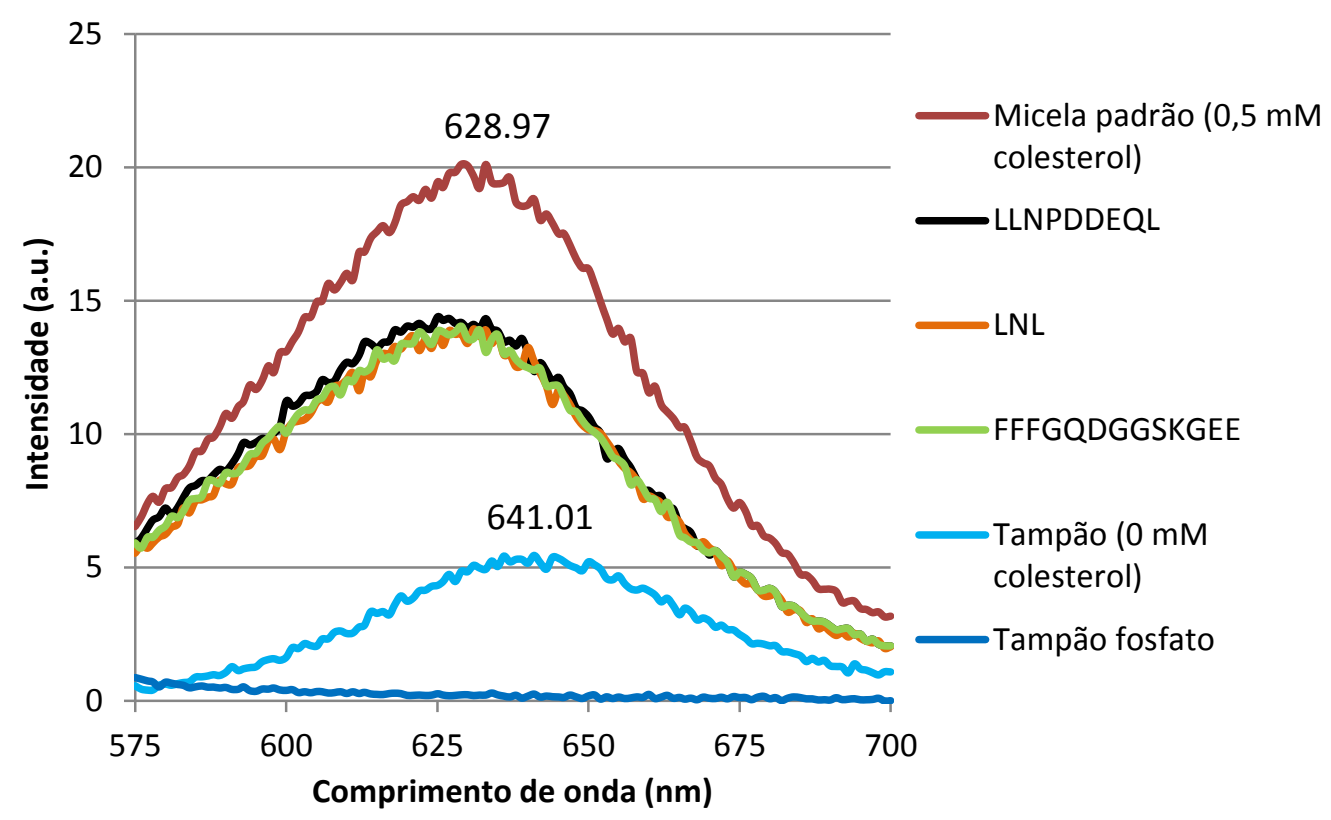

Fonte: Marques, M.R. (2017).

O achado mais relevante foi de que todas as amostras tiveram a capacidade de reduzir a intensidade do vermelho do nilo em comparação com a solução micelar padrão, o que sugere uma redução do colesterol dentro das micelas. Além disso, os peptídeos isolados também foram capazes de reduzir a internalização do colesterol com base na diminuição dos espectros máximos de emissão do vermelho do nilo (Figura 7). Estes resultados são similares aos resultados de solubilização micelar de colesterol (item 4.2.2).

Marianecci et al. (2012) e Stuart et al. (2005) relataram que como o vermelho do nilo tem um máximo de emissão dependente da polaridade, é possível discernir a formação de diferentes soluções complexas (ex: micelas, membranas com bicamadas, vesículas) por uma mudança no seu espectro. De acordo com a literatura, o vermelho do nilo mostra uma mudança para azul no seu espectro de emissão $\left(\lambda_{\mathrm{exc}}=549\right)$ quando ligado ao colesterol internalizado dentro das micelas (Greenspan e Fowler, 1985).

A Figura 8 mostra o efeito da fração $\leq 3 \mathrm{kDa}$ do hidrolisado no tamanho das micelas de colesterol. Em estudos anteriores (MARQUES, MANOLIO SOARES FREITAS, et al., 2015), na concentração de $1 \mathrm{mg} / \mathrm{mL}$ de fração $\leq 3 \mathrm{kDa}$ de hidrolisado já foi suficiente para dificultar a solubilização do colesterol, contudo, como pode se 
inferir do gráfico abaixo, o tamanho das micelas não foi alterado na mesma concentração. Somente na presença de concentrações de maiores de $100 \mathrm{mg} / \mathrm{mL}$, obteve-se um aumento significativo do tamanho das micelas.

Figura 8: Efeito da fração $\leq 3 \mathrm{kDa}$ do hidrolisado da proteína do feijão caupi no tamanho das micelas de colesterol (média \pm DP).

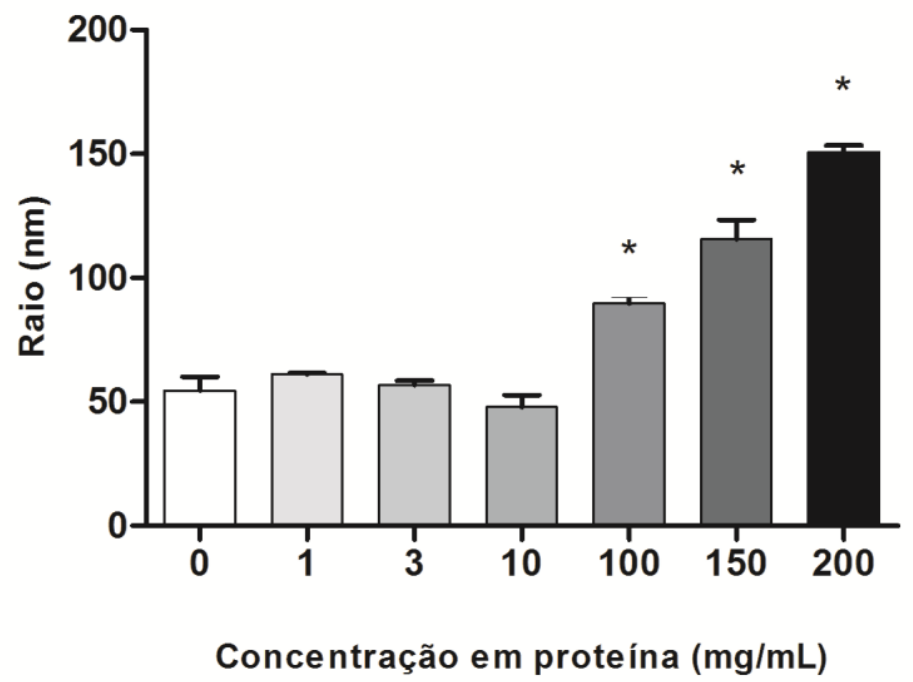

Fonte: Marques, M.R. (2017).

O presente estudo está de acordo com Khoshakhlagh et al. (2015) que provaram a possibilidade de ocorrer cenários variados. Num sistema de administração de fármaco baseado em micelas de colesterol, Khoshakhlagh e colaboradores não demonstraram qualquer relação linear entre a solubilização de muitas drogas com um aumento ou diminuição do tamanho das micelas. Além disso, provaram que as diferenças na composição de micelas, em termos de concentração de colesterol, por exemplo, podem afetar fortemente a solubilidade dos fármacos. 
Figura 9: Efeito dos peptídeos do caupi no tamanho das micelas de colesterol. (média \pm DP). ( $\left.^{*}\right) p<0,05$ comparado à micela padrão pelo teste $t$-Student.

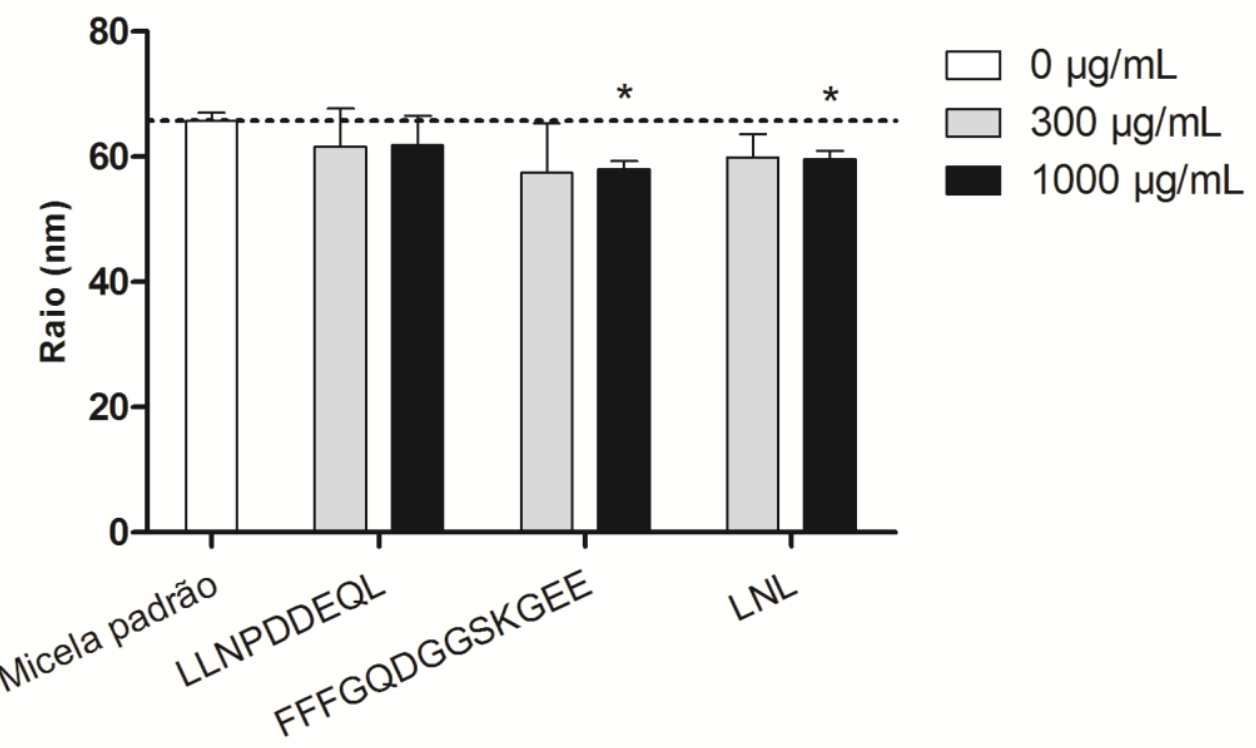

Peptídeos

Fonte: Marques, M.R. (2017).

A partir dos dados na Figura 9, fica evidente que os peptídeos isolados do caupi são mais eficazes na diminuição do tamanho da micela do que o hidrolisado. Entre todos os peptídeos testados, as sequências FFFGQDGGSKGEE e LNL mostraram-se mais ativos a $1000 \mu \mathrm{g} / \mathrm{mL}$, reduzindo o tamanho da micela para $58 \pm 1,29$ nm e 59,6 $\pm 1,36$, respectivamente, diferentemente da fração do hidrolisado.

Embora a proteína de caupi tenha mostrado ser capaz de reduzir a solubilidade de colesterol nas micelas, a digestão enzimática de toda a proteína pode levar a certas alterações químicas no produto final. Portanto, a fração hidrolisada alterada pode ser incapaz de interferir em baixas concentrações a ponto de alterar o raio das micelas, comparado, por exemplo, com outros compostos tais como fitoesteróis (MATSUOKA et al., 2012). Mesmo os fitoesteróis são capazes de insolubilizarem o colesterol sem interferir no tamanho das micelas (BROWN,A.W. 2010).

\subsubsection{Solubilização micelar do colesterol in vitro.}

A dieta é uma importante fonte de colesterol e o seu consumo diário de até $200 \mathrm{mg}$ é uma das metas para o controle das dislipidemias e aterosclerose 
(CATAPANO et al., 2016). Existem evidências suficientes de que compostos bioativos presentes em alimentos diminuem a absorção intestinal de colesterol, como fibras dietéticas e os fitoesteróis. A principal explicação para o efeito bioativo é a ação desses compostos impedindo a solubilidade micelar do colesterol. A Figura 10 mostra o percentual de solubilização do colesterol na presença $\leq 3 \mathrm{kDa}$ do hidrolisado de feijão caupi.

Figura 10: Percentual de solubilização do colesterol na presença da fração $\leq 3 \mathrm{kDa}$ do hidrolisado de feijão caupi comparado à micela padrão (sem adição de hidrolisado).
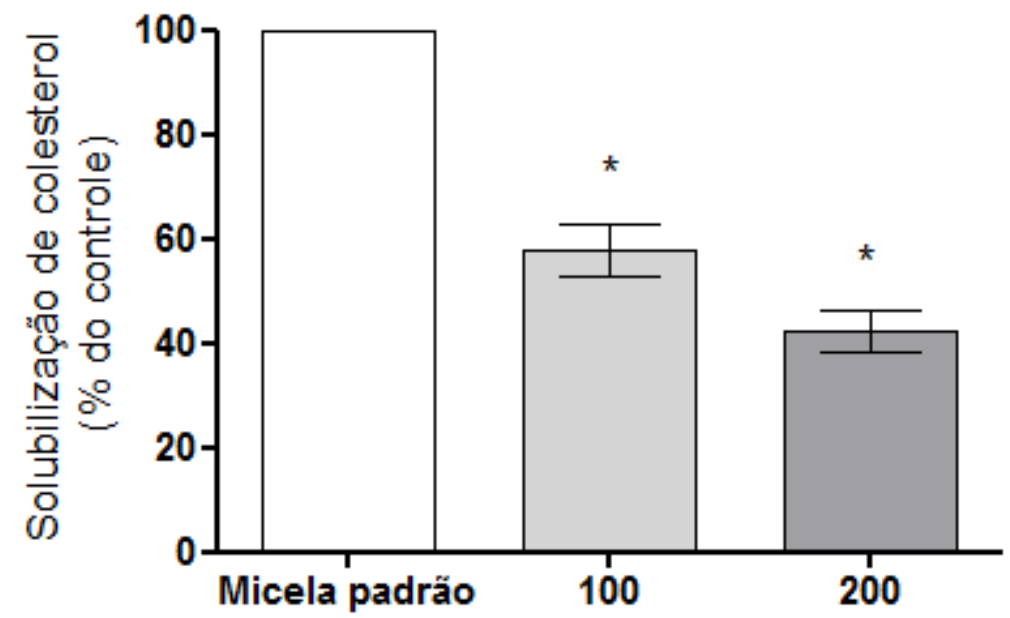

Concentração do hidrolisado $(\mathrm{mg} / \mathrm{mL})$

Fonte:

Marques, M.R. (2017).

A solubilidade de colesterol reduz em aproximadamente 50-60 \% após a adição da fração $\leq 3 \mathrm{kDa}$ do hidrolisado tendo efeito dose dependente. Os resultados encontrados por Matsuoka et. al. (2012) demonstram ser variáveis os resultados a depender do composto teste utilizado. O Colestanol, o $\beta$-sitosterol e o colesteril oleato foram os mais efetivos ao diminuir a solubilidade do colesterol das micelas, com até 10 vezes menos colesterol internalizado.

Estudo anterior com concentração menor da fração $\leq 3 \mathrm{kDa}$ do hidrolisado de feijão caupi (1 $\mathrm{mg} / \mathrm{mL}$ ) obteve $5,2 \%$ de inibição da solubilização do colesterol (MARQUES, MANOLIO SOARES FREITAS, et al., 2015). O estudo de Megias e colaboradores (2009) com hidrolisados do girassol na concentração $1 \mathrm{mg} / \mathrm{mL}$ 
obtiveram inibição de 60 \% na solubilização do colesterol. Da mesma forma, os hidrolisados proteicos de grão de bico foram descritos como capazes e inibir $50 \%$ da solubilização micelar do colesterol na concentração e $2 \mathrm{mg} / \mathrm{mL}$ (Del Mar Yust et al., 2012).

Figura 11: Percentual de solubilização do colesterol na presença de três peptídeos sintéticos análogos aos provenientes do feijão caupi comparado à micela padrão, sem adição de peptídeos.

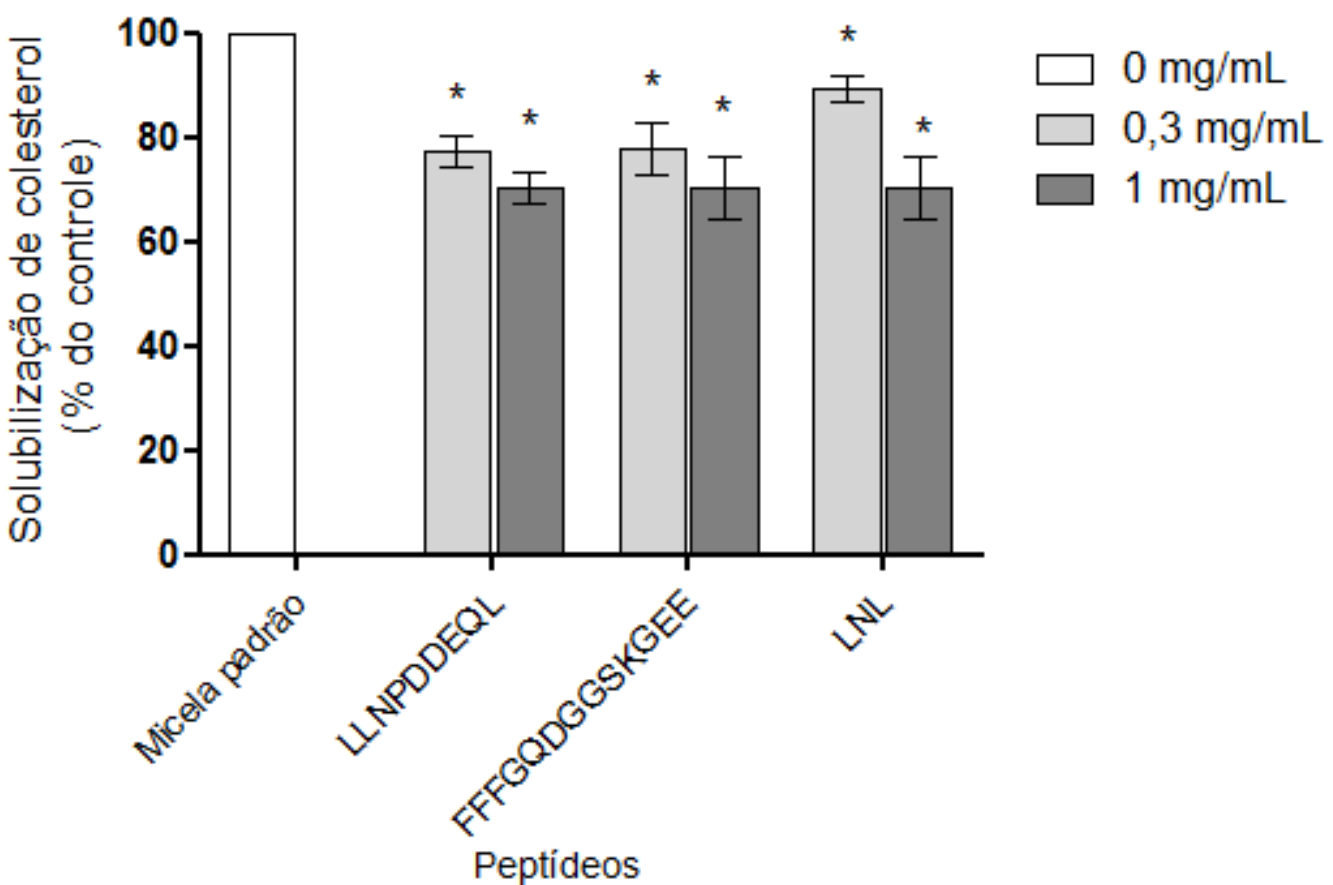

Fonte: Marques, M.R. (2017).

Assim, como pode ser visto na Figura 11, os peptídeos sintéticos isolados também foram capazes de insolubilizar o colesterol de maneira dose dependente. Até o momento, não se conhece nenhum efeito comprovado de peptídeos isolados de feijão caupi nesse mecanismo. Estudos in vitro com peptídeos atuando na solubilidade do colesterol micelar intestinal são raros. Na literatura o peptídeo mais amplamente estudado é o IIAEK proveniente da $\beta$-lactoglobulina do leite que possui a capacidade de se ligar aos ácidos biliares, impactando na capacidade de solubilização do colesterol (NAGAOKA et al., 2001).

A ação dos peptídeos nas micelas do colesterol ainda é incerta. Postula-se que peptídeos hidrofóbicos são mais propensos a interferir na formação estrutural da 
micela por formar amboientes hidrofóbido e assim competir com o colesterol, da mesma forma que os fitoesteróis (Marrink e Mark, 2002; Megías et al., 2009). Contudo, mesmo possuindo hidrofobicidade diferente, os resultados absolutos entre os peptídeos são semelhantes.

\subsubsection{Solubilização micelar da fosfatidilcolina}

A Figura 12 abaixo mostra o resultado da solubilização da fosfatidilcolina micelar na presença da fração $\leq 3 \mathrm{kDa}$ do hidrolisado de feijão caupi.

Figura 12: Percentual de solubilização de fosfatidilcolina na presença da fração $\leq 3 \mathrm{kDa}$ do hidrolisado de feijão caupi comparado à micela sem adição de hidrolisado (média $\pm \mathrm{DP}) .\left(^{*}\right) \mathrm{p}<0,05$ comparado à micela padrão pelo teste $t$-Student.

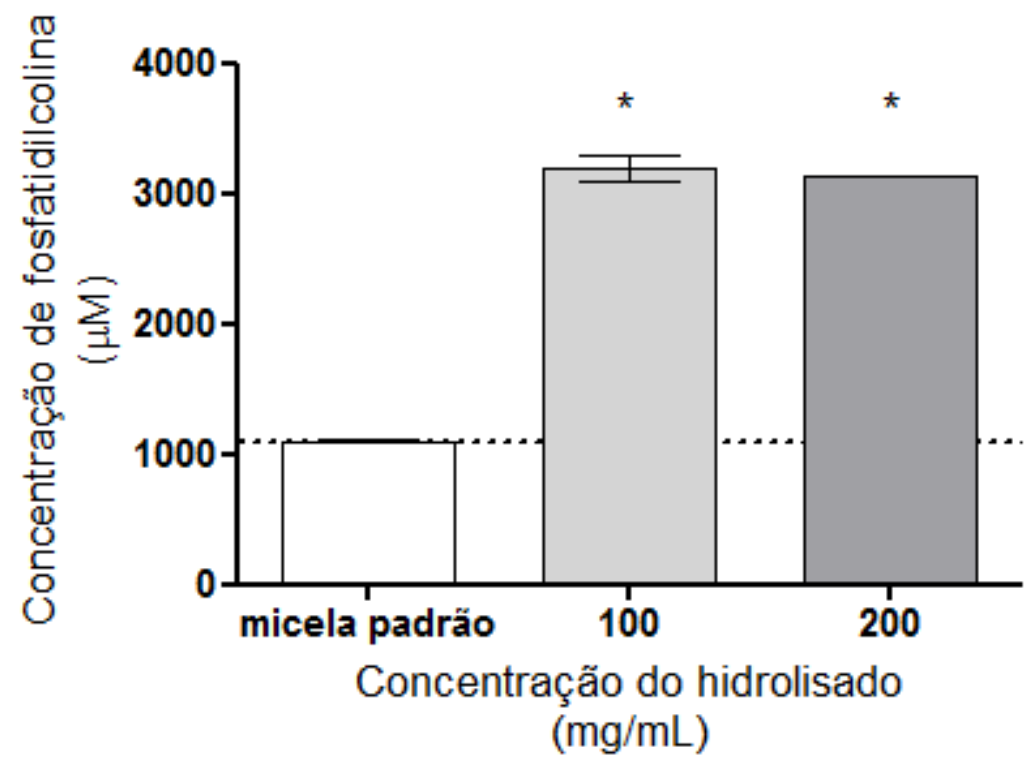

Fonte: Marques, M.R. (2017).

Isolados proteicos e fosfolipídeos podem apresentar propriedades com efeitos sinérgicos ou antagônicos na estabilidade de emulsões. Interações entre proteínas e fosfolipídeos podem levar a mudanças na atividade de superfície, modificações na estrutura da proteína, e incorporação da proteína na estrutura sufactante das micelas e vesículas (SCURIATTI et al., 2003). 
$\mathrm{Na}$ literatura existem relatos de vários componentes de alimentos que são capazes de se ligarem à fosfatidilcolina. O estudo espectroscópico realizado com a curcumina para elucidar a interação com a fosfatidilcolina sugere que o aumento da absorbância é consequência da formação de um ambiente hidrofóbico nas micelas, no qual a curcumina se liga às micelas de fosfatidilcolina (451 nm excitação) (Began et al., 1999). O aumento de absorbância ocorre também na presença de peptídeos, contudo, com menor intensidade (Figura 13).

Figura 13: Percentual de solubilização de fosfatidilcolina na presença de três peptídeos sintéticos análogos aos provenientes do feijão caupi comparado à micela padrão, sem adição de peptídeos (média $\pm \mathrm{DP}) .\left(^{*}\right) \mathrm{p}<0,05$. teste $t$-Student.

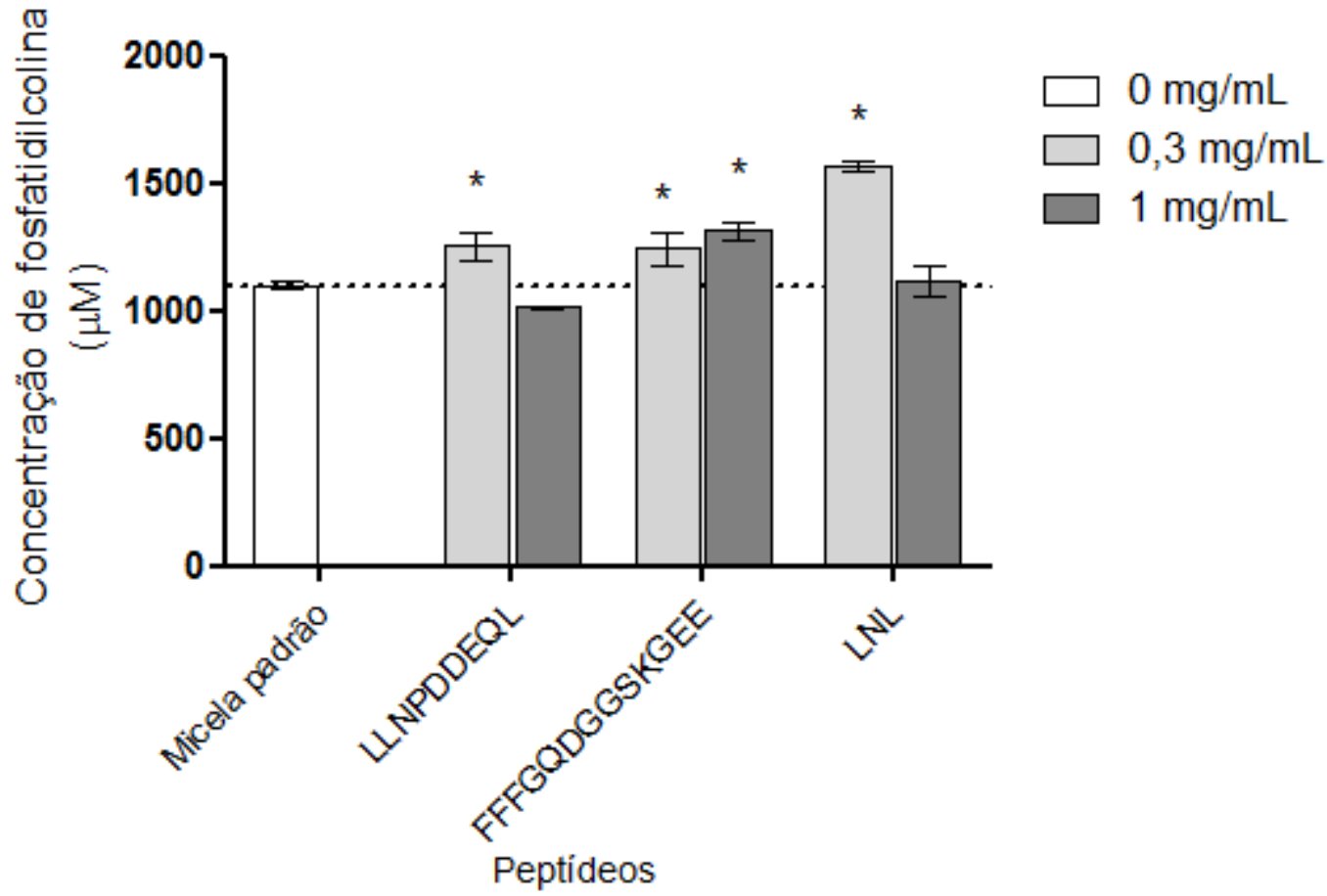

Fonte: Marques, M.R. (2017).

Os peptídeos isolados do feijão caupi exibem discreta ação, com destaque para a sequência LNL, contudo o efeito não parece ser dose dependente. Já é conhecido a capacidade da proteína da soja se associar a vesículas de fosfatidilcolina, funcionando como agente emulsificante.Essa interação ocorre nas regiões mais hidrofóbicas da proteína (LI et al., 2014). Baseado na constatação anteior, a hidrofobicidade do peptídeo LNL pode explicar o efeito destacado em 
relação aos outros peptídeos ( $\approx 50 \%)$. Um importante alérgeno do leite, a $\alpha$ lactalbumina, foi descrita como capaz de penetrar em vesículas de fosfatidilcolina por interação hidrofóbica, com consequente aumento da polarização de fluorescência, comprovando a relação entre proteínas e fosfolipídeos (ESPEJO-CARPIO et al., 2016).

O mecanismo de ação das proteínas nas micelas de colesterol não parece ser o mesmo do encontrado na literatura para polifenóis. A adição de epigalocatequina galato atua eliminando a fosfatidilcolina da formação estrutural da micela, rompendo a estrutura micelar (KOBAYASHI et al., 2014). A atuação das proteínas parece ser de reorganização da estrutura; ao mudar a composição das micelas por internalizar peptídeos hidrofóbicos, o colesterol deixa de ser solubilizado ou é incorporado de forma ineficiente pela nova micela mista formada. No fim, mesmo por mecanismos diferentes o efeito resultante é a insolubilização do colesterol.

\subsubsection{Interação da fração $\leq 3 \mathrm{kDa}$ do hidrolisado e peptídeos com ácidos biliares}

A Figura 14 resume a interação da fração $\leq 3 \mathrm{kDa}$ do hidrolisado com os ácidos biliares das micelas de colesterol. É possível observar que a fração $\leq 3 k D a$ do hidrolisado é capaz de se ligar aos ácidos biliares da micela, contudo, somente na concentração de $200 \mathrm{mg} / \mathrm{mL}$ em proteína. 
Figura 14: Interação da fração $\leq 3 \mathrm{kDa}$ do hidrolisado com ácidos biliares das micelas de colesterol. A colestiramina foi utilizada como controle positivo (média $\pm \mathrm{DP}) .\left(^{*}\right) \mathrm{p}<0,05$ comparado à micela padrão pelo teste $t$-Student.

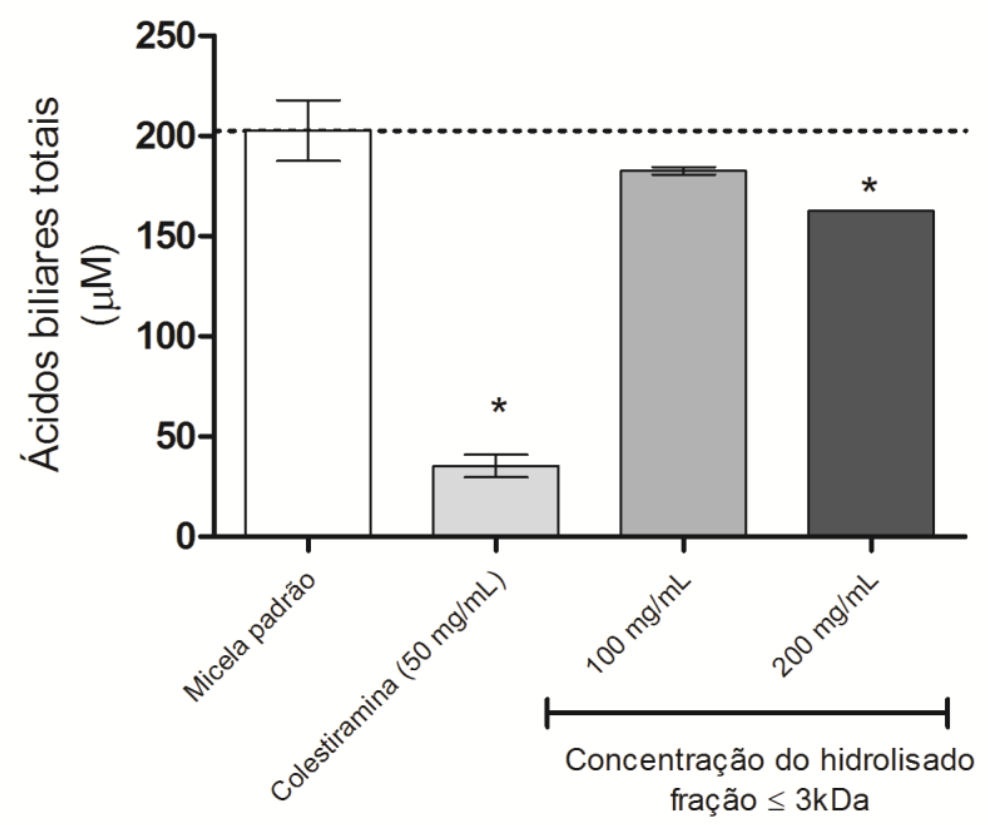

Fonte: Marques, M.R. (2017).

A colestiramina é uma conhecida droga capaz de se ligar aos ácidos biliares intestinais e tem sido utilizado como estratégia no tratamento da hipercolesterolemia. O grupo $\mathrm{COO}^{-}$dos ácidos biliares é o principal alvo estrutural para a troca iônica feita com as resinas catiônicas clinicamente utilizadas como sequestrantes de ácidos biliares. Proteínas alimentares como soja, arroz branco, peixes, leite de cabra e outras já foram descritas como capazes de serem sequestrantes de ácidos biliares. Este sequestro reduz a quantidade de ácidos biliares reciclados no fígado, e aumenta a síntese de ácidos biliares à custa de remover colesterol da corrente sanguínea (PÉREZ-GÁLVEZ et al., 2015; WANG et al., 2015; ESPEJO-CARPIO et al., 2016). 
Figura 15: Interação de três peptídeos sintéticos análogos aos provenientes do feijão caupi com ácidos biliares das micelas de colesterol. A colestiramina foi utilizada como controle positivo (média $\pm \mathrm{DP}) .\left(^{*}\right) \mathrm{p}<0,05$ comparado à micela padrão pelo teste $t$-Student.

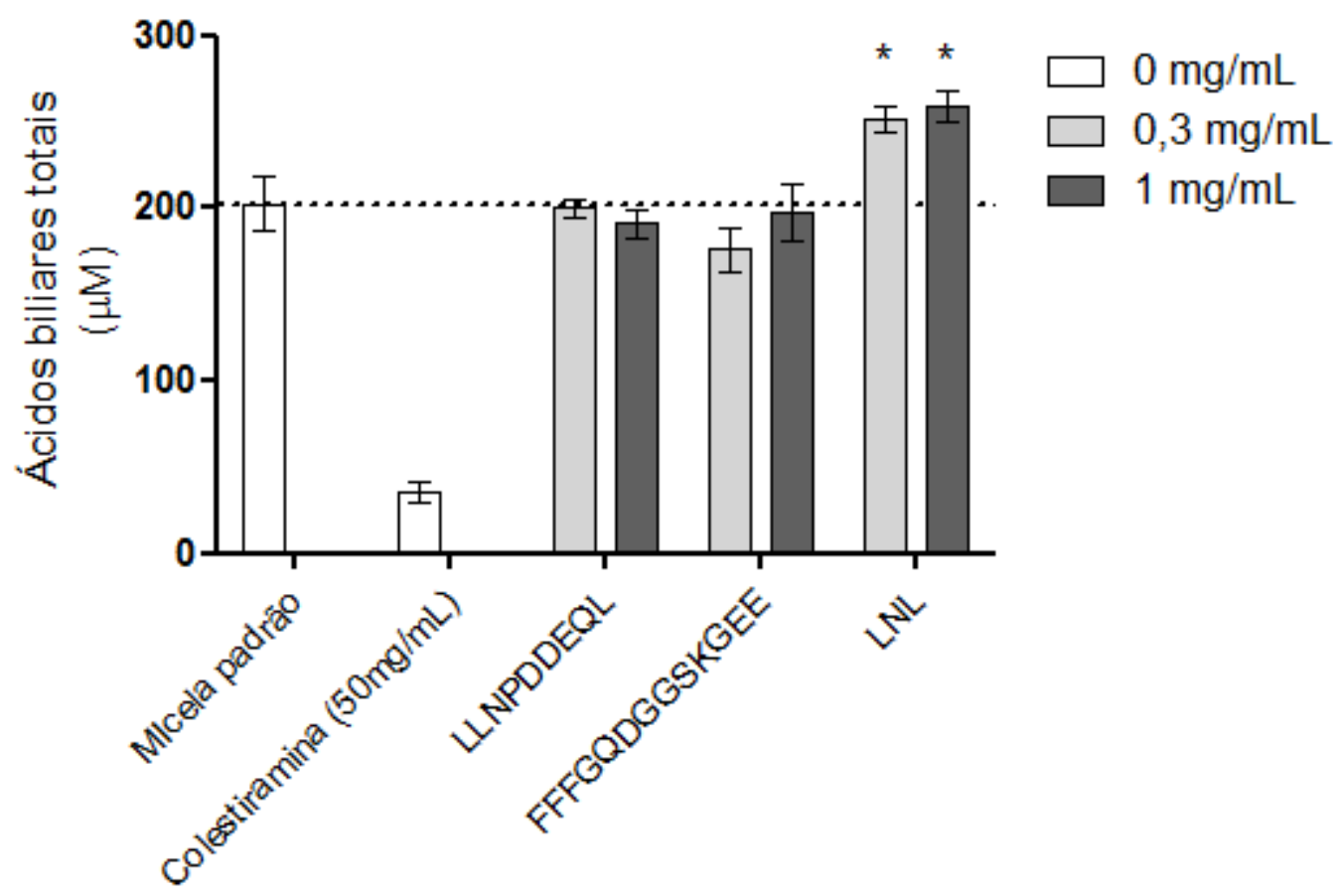

Peptídeos

Fonte: Marques, M.R. (2017).

De acordo com a Figura 15, não foram verificadas diferenças na presença dos peptídeos analisados, com exceção novamente do peptídeo LNL. O peptídeo da soja VAWWMY (soystatin) já foi descrito como capaz de se ligar ao taurocolato de sódio a níveis estatisticamente iguais ao efeito da colestiramina associado à diminuição da solubilidade do colesterol (NAGAOKA et al., 2010). Até o momento, há escassa informação sobre a relação estrutura-função da dos peptídeos/proteínas e o sequestro de ácidos biliares intestinais. A literatura versa sobre a baixa digestibilidade e quantidades de resíduos de aminoácidos hidrofóbicos como cruciais para o sequestro de ácidos biliares (MOHAN e UDENIGWE, 2015).

O estudo de Tiengo e colaboradores (2011) mostrou que o efeito do hidrolisados proteicos de amaranto e de sua capacidade de se ligar aos ácidos biliares podem variar também a depender das condições de hidrólise, tipo de enzima, 
e o tipo de ácido biliar. No entanto não é comum o efeito oposto: a solubilização de ácidos biliares (peptídeo LNL).

A característica interessante do peptídeo LNL de solvatar os ácido biliares vai ao encontro do extenso estudo de Wang e Carey (1996) sobre os mecanismos de cristalização de colesterol e formação de cálculos biliares. Assim, o comportamento do peptídeo LNL deve ser interpretado com cuidado. Apesar de não se ligar ao taurocolato e impedir a formação micelar, o peptídeo induziu uma mudança na composição, aumentando a solubilidade dos ácidos biliares no sistema e em consequência diminuindo a razão [fosfolipídeo]/([ácidos biliares+fosfolipídeo]). Isso implica na maior precipitação de cristais de colesterol, insolubilizando-o.

\subsubsection{Separação e quantificação da fração de cristais de colesterol}

Com o intuito de constatar a possível formação de cristais de colesterol após contato com a fração $\leq 3 \mathrm{kDa}$ do hidrolisado e dos peptídeos do caupi, procedeu-se à separação das fase micelar da fração de cristais de colesterol por ultracentrifugação. A Figura 16 abaixo ilustra os resultados da concentração de colesterol cristalizado após adicionar a fração $\leq 3 \mathrm{kDa}$ do hidrolisado de feijão caupi. 
Figura 16: Quantificação de cristais de colesterol formados na presença e na ausência da fração $\leq 3 \mathrm{kDa}$ do hidrolisado (média $\pm \mathrm{DP}) . \quad\left({ }^{*}\right) \quad \mathrm{p}<0,05$ comparado à micela padrão na ausência de hidrolisado $(0 \mathrm{mg} / \mathrm{mL})$ pelo teste $t$-Student.

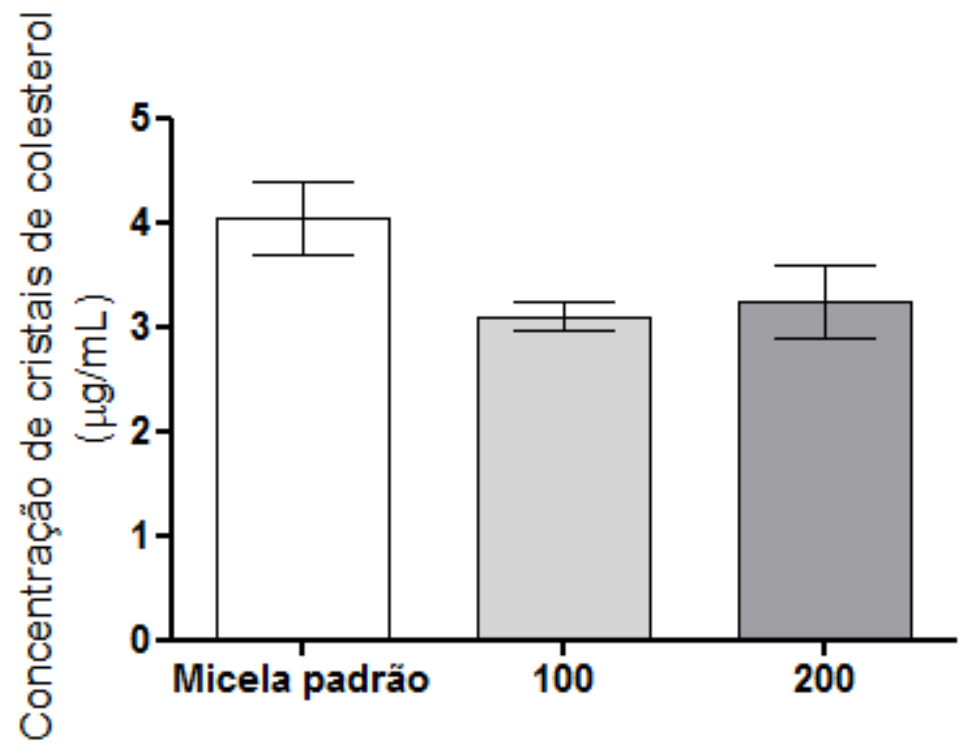

Concentração do hidrolisado $(\mathrm{mg} / \mathrm{mL})$

Fonte: Marques, M.R. (2017).

Apesar de insolubilizar o colesterol, a fração $\leq 3 \mathrm{kDa}$ do hidrolisado não promoveu a cristalização dos resíduos. Contudo, de acordo com a Figura 17, na presença de peptídeos isolados, observou-se uma precipitação significativa de cristais de colesterol. Estes resultados, apesar de não parecerem ser dose dependente, confirmam a insolubilização do colesterol por meio da alteração da razão [fosfolipídeo]/([ácidos biliares+fosfolipídeo]) e formação de cristais. 
Figura 17: Quantificação de cristais de colesterol formados na presença e na ausência de três peptídeos sintéticos análogos aos provenientes do feijão caupi (média \pm DP). $\left(^{*}\right) p<0,05$ comparado à micela padrão pelo teste $t$-Student.

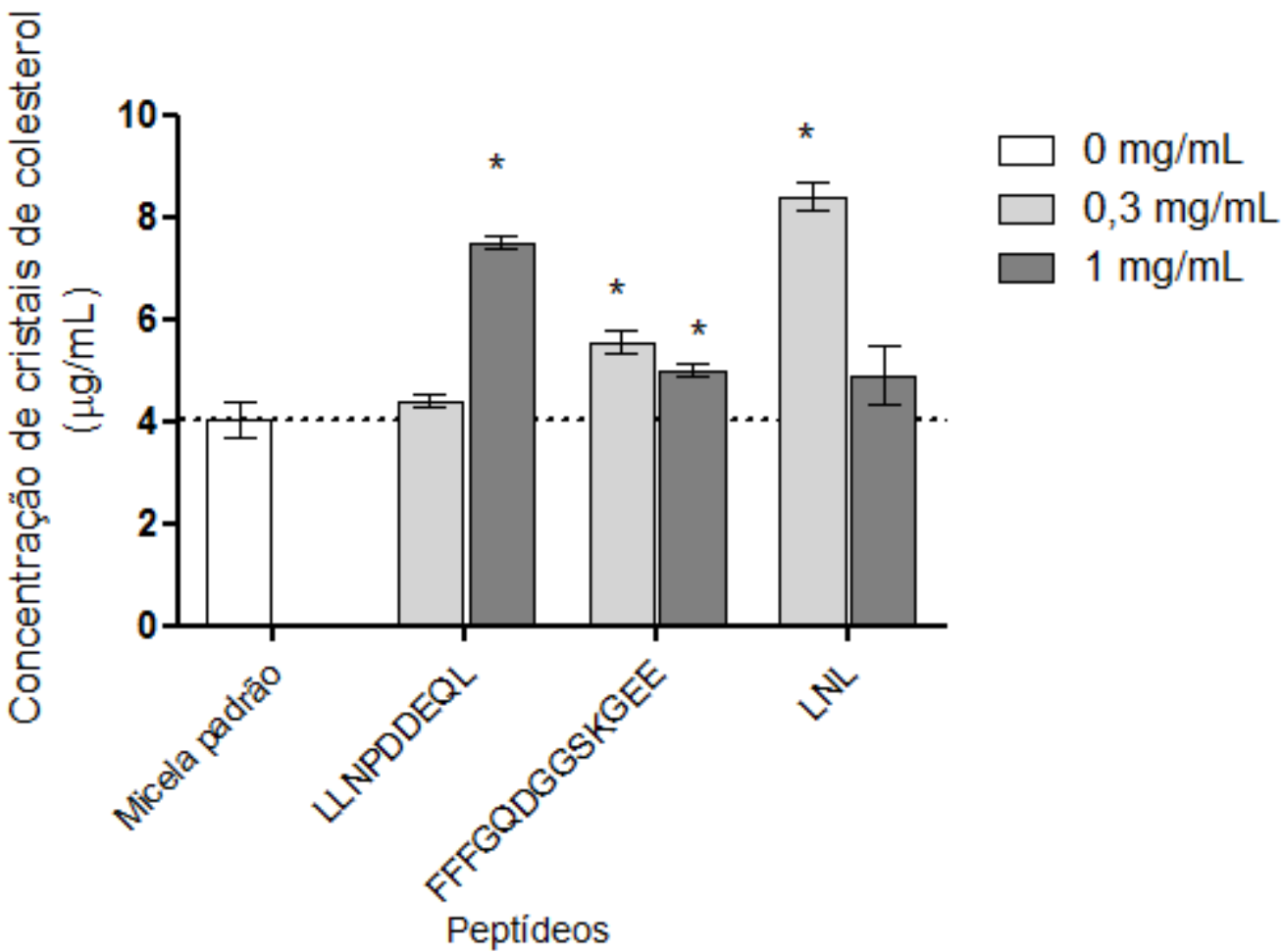

Fonte: Marques, M.R. (2017).

Estudos com proteínas alimentares descrevem os mais variados mecanismos possíveis de interação proteína/peptídeo-micela, contudo, nenhum deles detalha de que forma essa interação acontece, seja interagindo com o colesterol, com a fosfatidilcolina ou ácidos biliares (KOBAYASHI et al., 2014; PÉREZ-GÁLVEZ et al., 2015). Neste estudo, fica claro que o mecanismo de competição pelo espaço intramicelar com o colesterol se dá pela interação indireta com os componentes micelares e não diretamente com o colesterol. 


\subsection{VIA ENDÓGENA: permeação celular, expressão gênica de transportadores e da biossíntese do colesterol}

\subsubsection{Permeação celular através da monocamada de células Caco-2}

Os peptídeos derivados de alimentos satisfazem as propriedades desejadas de modulação fisiológica saúde e menores efeitos colaterais em comparação com drogas. No entanto, muitos destes peptídeos têm aplicações práticas restritas, devido à sua instabilidade e baixa biodisponibilidade in vivo limitada. Assim, é crítico para peptídeos bioativos superar duas barreiras fisiológicas: a extensa degradação enzimática no trato gastrointestinal e a permeabilidade intestinal pequena (GLEESON, et. al. 2015).. Estudos anteriores tem demosntrado que as células Caco-2 expressam, pelo menos, oito peptidases de membrana na sua superfície apical, e estes exibem peptidases diferentes atividades em diferentes estádios de desenvolvimento (DING et al., 2015).

O conteúdo coletado após a permeação foi submetido à identificação para avaliar se os peptídeos do feijão caupi após a digestão são capazes de cruzar in vitro a barreira epitelial. A espectrometria de massas revelou mais de 180 peptídeos, contudo, somente aqueles com nível de confiança ALC $>50 \%$ foram considerados e destes, apenas um peptídeo foi capaz de permanecer intacto e foi considerado permeável através da monocamada de Caco-2 (Tabela 2). Para a identificação, foi considerado como ponto de corte um nível de confiança (disponibilizado pelo software PEAKS).

Uma opinião comum entre os pesquisadores é que, após extensa ação da enzima, apenas alguns di e tri peptídeos podem atravessar o epitélio intestinal. No entanto, esta não é a primeira evidência na literatura que descreve a possibilidade de resíduos grandes de peptídeos de permear células intestinais (PICARIELLO et al., 2013). 
Tabela 2: Peptídeo presente na parte basolateral e seu potencial de atividade biológica, propriedades físico-químicas e fonte proteica.

\begin{tabular}{|c|c|}
\hline Características & MELNAVSVVHS \\
\hline ALC escore $(\%)^{a}$ & 81 \\
\hline $\begin{array}{l}\text { Massa molecular observada /massa } \\
\text { molecular teórica }(\mathrm{Da})^{\mathrm{e}}\end{array}$ & $1184,5 / 1185,3$ \\
\hline Possível atividade biológica ${ }^{b}$ & $\begin{array}{l}\text { Inibidor de ECA (enzima conversora de angiotensina); } \\
\text { inibidor da aminopeptidase IV; Antioxidante. }\end{array}$ \\
\hline Razão total de hidrofobicidade $(\%)^{c}$ & 63,6 \\
\hline Ponto isoelétrico ${ }^{\mathrm{e}}$ & $\mathrm{pH} 5,13$ \\
\hline Fonte proteica $^{d}$ & $\begin{array}{l}\text { Lectina; subunidade } 2 \text { da NADH-plastoquinona } \\
\text { oxidoredutase. }\end{array}$ \\
\hline Escore de penetração celular ${ }^{\dagger}$ & 0,114 \\
\hline
\end{tabular}

\footnotetext{
a Peptídeos com PEAKS ALC (average local confidence) escore de $50 \%$ ou maior; presente na parte apical e basolateral das células Caco-2.

${ }^{\mathrm{b}}$ Determinado usando BIOPEP.

${ }^{c}$ Calculado como percentual de resíduos hidrofóbicos (I, V, L, F, C, M, A, W) na sequencia dos peptídeos.

'Determinado com uso do BLAST tool (basttp algoritmo), banco de dados non-redundant protein sequence, organismo Vigna unguiculata (L.) Walp. taxid: 3917.

e Determinado com o uso do Innovagen's peptide property calculator

${ }^{\mathrm{f}}$ CPPpred (score: 0 - penetração celular improvável; 1 -penetração celular provável)
}

Hidrolisados de caseína a partir do leite após digestão gastrintestinal in vitro e, subsequentemente fracionamento por peso molecular, revelou que a fração com o mais alto teor de aminoácidos mostrou uma maior resistência à digestão humana. Admite-se que os dipeptídeos e oligopeptídeos contendo prolina (P), valina (V) e treonina na porção C-terminal e os aminoácidos valina e ácido glutâmico (E) na posição $\mathrm{N}$-terminal, podem resistir peptidases específicas na borda em escova. Contudo, apesar da grande presença de valina na estrutura, nenhuma destas condições pode explicar o transporte intacto destas sequências (AO e LI, 2013; WANG et al., 2016).

Estudos anteriores confirmam a hipótese de que a proteína dietética pode influenciar respostas adaptativas nas células intestinais, peptídeos e aminoácidos que expressam transportadores. O conhecido transportador de borda em escova $\mathrm{H}^{+}$Pep-T1 utiliza um gradiente de hidrogênio para transportar di e tripeptideos para o outro lado borda em escova e transferi-los para o líquido extracelular (HANSEN et al., 2015). Em contraste com resultados anteriores e como sugere o CPPpred tool, os 
peptídeos identificados com 11 resíduos, dificilmente conseguiriam penetrar em células intestinais por transportadores específicos (Tabela 2).

O transporte dos peptídeos nesse estudo pode ser explicado pelo transporte paracelular passivo. O relaxamento das "tight junctions" é influenciado por vários fatores: enzimas, neuropeptídeos, neurotransmissores, citocinas pró-inflamatórias, radicais livres, peptídeos hidrofóbicos e lectinas dietéticas (LERNER e MATTHIAS, 2015). Independente da isolada de cada peptídeo, algum componente do hidrolisado que não foi absorvido pode ter facilitado o relaxamento das "tight junctions". Estes resultados parecem ser consistentes com outras pesquisas que mostraram que o hidrolisado de queijo foi capaz de impedir o epitopo alérgeno da ovalbumina de ser absorvido por células Caco-2. Isso também reafirma a ação sinérgica de vários peptídeos (TANABE, 2012; GALLEGO et al., 2016).

\subsubsection{Expressão gênica dos transportadores NPC1L1, ABCA1 e ABCG1 em células Caco-2}

As células Caco-2, após a diferenciação espontânea em uma monocamada de células, expressam várias características morfológicas e funcionais do enterócitos maduros. Antes de começar, foi importante determinar se o hidrolisado poderia perturbar a viabilidade celular e a formação da monocamada. Avaliado por citotoxicidade celular e resistência transepitelial, nenhuma perturbação significativa da função de barreira da mucosa e diferenciação celular foi encontrada (Figura 18). Portanto, pode-se concluir que o fração $\leq 3 \mathrm{kDa}$ do hidrolisado não exerce grandes efeitos citotóxicos em células Caco-2 durante o tempo e as concentrações utilizados nos ensaios de permeabilidade e a expressão dos genes. 
Figura 18: Percentual de viabilidade celular das linhagens Caco-2 na presença de duas concentrações da fração $\leq 3 \mathrm{kDa}$ do hidrolisado em diferentes tempos. (Média \pm DP).

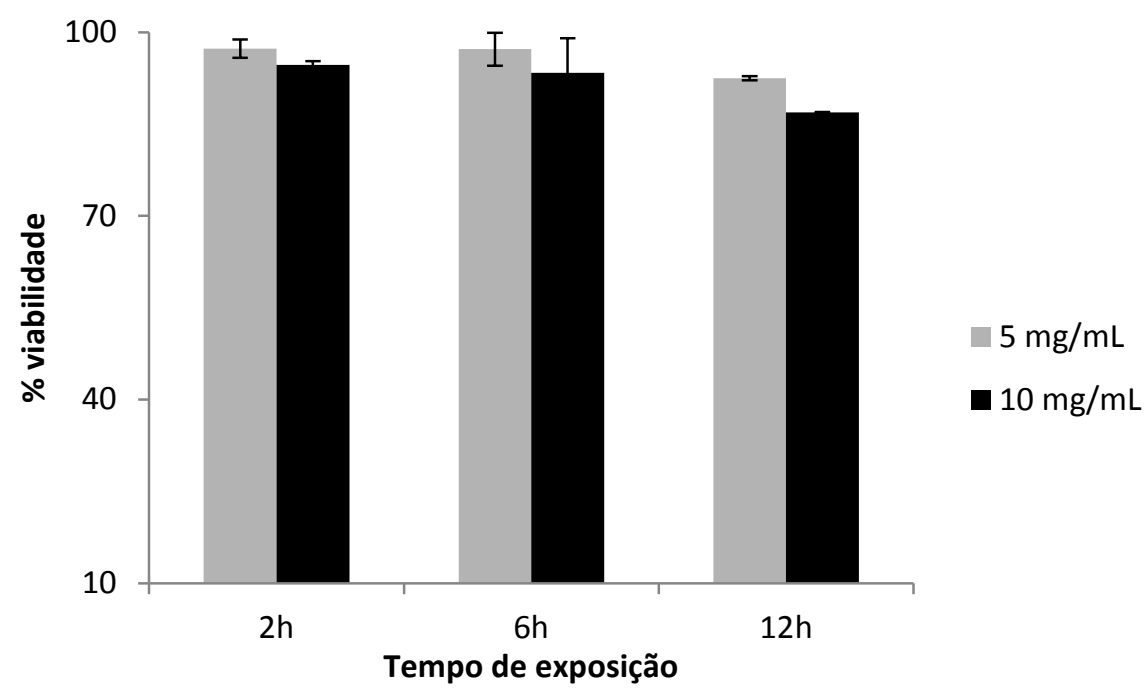

Fonte: Marques, M.R. (2017).

A figura 19 sistematiza os resultados de expressão gênica dos transportadores de colesterol nas células intestinais. Fica evidente que o hidrolisado $\leq 3 \mathrm{kDa}$ possui efeito nos genes NPC1L1, ABCA1 e ABCG1. Após $6 \mathrm{~h}$ e $12 \mathrm{~h}$ de incubação, o tratamento diminuiu a expressão dos genes NPC1L1 e ABCA1 em todas as concentrações utilizadas. Por outro lado, o RNAm da ABCG1 aumentou em concentrações de 2,5 e $5 \mathrm{mg} / \mathrm{mL}$ após 6 h e 12 h de exposição. 
Figura 19: Expressão de RNAm dos gene NPC1L1 (A), ABCA1 (B) e ABCG1 (C) sob diferentes condições de tempo e concentração de hidrolisado. (Média \pm Erro Padrão). $\left({ }^{*}\right) p<0,05$ comparado ao controle; (\#) $\mathrm{p}<0,05$ comparando diferentes tempos na mesma concentração.

৫
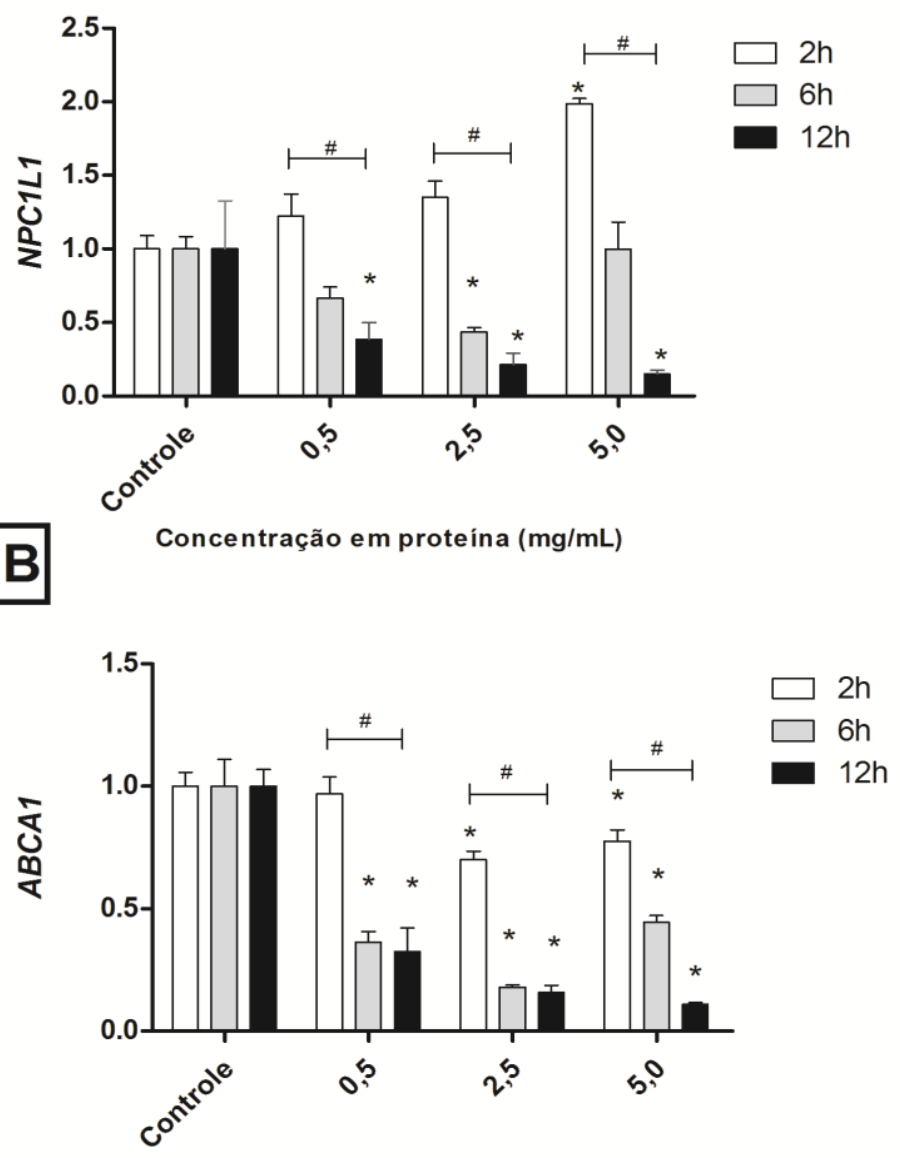

c

Concentração em proteína $(\mathrm{mg} / \mathrm{mL})$

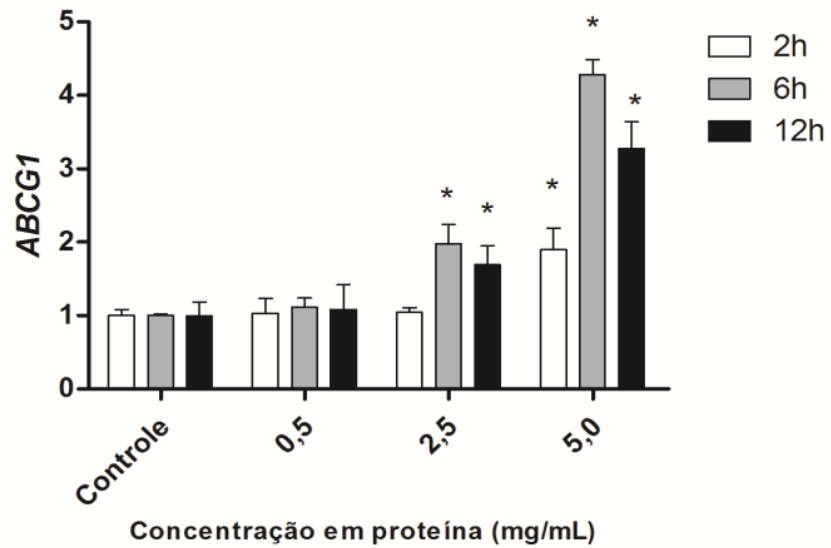

Fonte: Marques, M.R. (2017). 
Os resultados mostram que: a digestão humana é capaz de liberar peptídeos hipocolesterolêmicos, e o possível mecanismo de ação desses peptídeos também se dá a nível celular/genético. A diminuição na expressão de NPC1L1 pode promover uma diminuição importante da absorção de colesterol por meio da alimentação com consequente liberação de colesterol nas fezes. Os resultados do consumo do isolado proteico e do feijão caupi integral por hamsters já mostrou que o colesterol pode ser liberado nas fezes (FROTA, K. D. M. G. et al., 2008). Outros componentes alimentares já são descritos como capazes de inibir a captação do colesterol em hamsters ao diminuir a expressão do gene NPC1L1, como a sesamina (lignana isolada do óleo de gergelim) e fitoesteróis (LIANG et al., 2015).

As proteínas do tipo $A B C A 1$ e $A B C G 1$ possuem um papel importante no efluxo do colesterol, porém, de maneiras distintas. A proteína $A B C A 1$ promove 0 efluxo de colesterol do fígado para se ligar na apo-A1 que é a proteína majoritária do HDL colesterol. A proteína ABCG1 promove o efluxo de colesterol na forma de óxido de esteróis, como parte da bile. De acordo com os resultados, podemos pressupor que o papel dos peptídeos do feijão caupi é mais promissor no sentido de promover a liberação do colesterol pela via biliar, pois houve aumento da expressão do gene ABCG1 proporcionalmente ao tempo e concentração.

Em humanos, o colesterol HDL aumentou $2.7 \%$ após o consumo de $25 \mathrm{~g} / \mathrm{dia}$ de isolado proteico de caupi (Frota et al., 2015). Estes resultados estão de acordo com aqueles, indicando que o aumento da expressão de ABCG1 pode explicar as mudanças nas concentrações de HDL em humanos (Figura 19B). Contudo, as diferenças observadas entre a expressão de $A B C A 1 / A B C G 1$ se devem à efeitos compensatórios já conhecidos e bem estabelecidos em estudos com ratos "knockout" ABCG1\% (Figura 18C) (RANALLETTA et al., 2006).

\subsubsection{Efeito do peptídeo permeado na expressão dos genes $H M G C R, L D L R$,}

\section{AMPK1, SREBP2 e LXRa em células HepG2.}

A próxima questão a esclarecer foi de que uma vez no líquido extracelular se o peptídeo absorvido pelo epitélio intestinal pode atuar em um órgão-alvo ou via específica. Assim, dois peptídeos (MELNAVSVVHS e MELNAVSVVSH) identificados 
no compartimento basolateral da placa Transwe $\| \mathbb{A}$ foram sintetizados e testados na expressão de genes relacionados com o colesterol: SREBP2, AMPK1, LXRa, HMGCR e $L D L R$.

Como pode se observar a partir dos dados na Figura 20 e 21, os peptídeos sintéticos utilizados na concentração de $250 \mu \mathrm{M}$ podem danificar significativamente as células hepáticas (100 \% de morte celular). No entanto, em concentrações inferiores a $100 \mu \mathrm{M}$, não há atividade citotóxica crítica. Com base nestes resultados, somente concentrações seguras dos peptídeos foram utilizados para expressão dos genes $(50 \mu \mathrm{M}$ e $100 \mu \mathrm{M})$.

Figura 20: Percentual de viabilidade celular das linhagens HepG2 na presença de duas concentrações do peptídeo MELNAVSVVHS em diferentes tempos. (Média \pm DP).

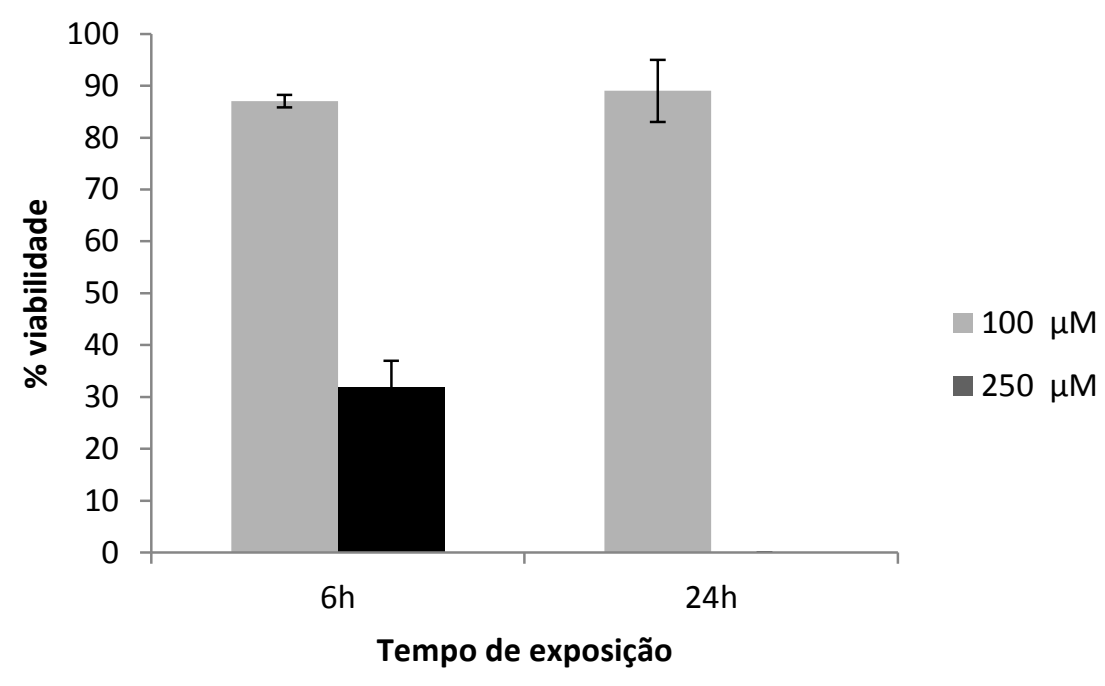

Fonte: Marques, M.R. (2017). 
Figura 21: Percentual de viabilidade celular das linhagens HepG2 na presença de duas concentrações do peptídeo MELNAVSVVSH em diferentes tempos. (Média \pm DP).

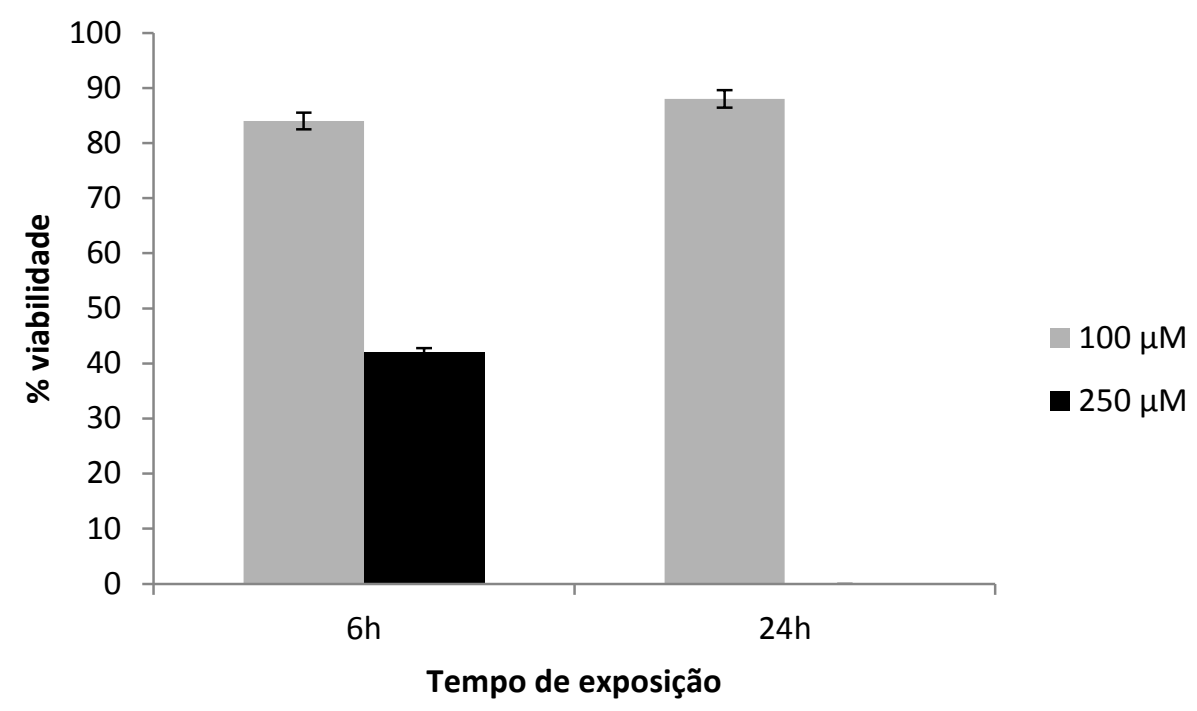

Fonte: Marques, M.R. (2017).

A Figuras 22 apresenta o efeito do peptídeo MELNAVSVVSH na expressão relativa de RNAm em células de hepatoma humano. A linhagem celular de hepatoma humano (HepG2) mantém funções bioquímicas normais das células do parênquima do fígado, que expressam as principais enzimas necessárias para o metabolismo do colesterol. O que é interessante nestes dados é que a diferença entre os dois peptídeos avaliados foi apenas no C-terminal. De acordo com estes números, podemos inferir que o peptídeo com final histidina-serina, de forma tempo dependente, reduz a expressão gênica de HMGCR e $L D L R$ por regulação negativa da via dos SREBP's. A expressão gênica foi a única análise capaz de discriminar o peptídeo correto na porção C-terminal comparado ao outro peptídeo testado.

O fator de transcrição SREBP2 é responsável pela transcrição das isoformas $L D L R$ e HMGCR, e a maturação da SREBP2 é regulada pelas concentrações de colesterol intracelular. Quando a concentração de colesterol está aumentada, a produção de $L D L R$ e HMCGR é reduzida. Em conjunto, esta resposta reguladora diminui o colesterol do plasma bem como da síntese endógena. 
Figura 22: Expressão de RNAm dos gene SREBP2 (A), AMPK1 (B) e LXRa (C), HMGCR (D), LDLR (E) sob diferentes condições de tempo e concentração do peptídeo MELNAVSVVSH. (Média \pm Erro Padrão).

A

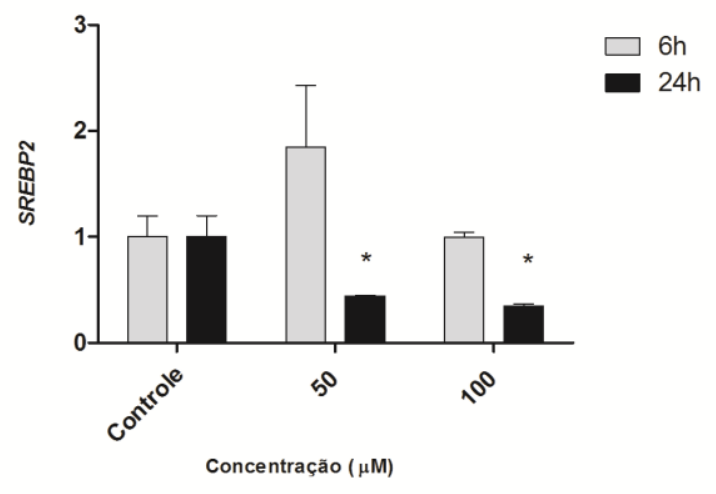

C

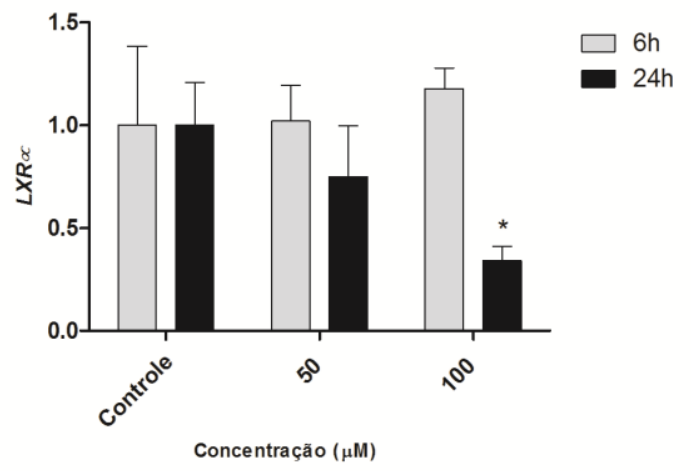

B

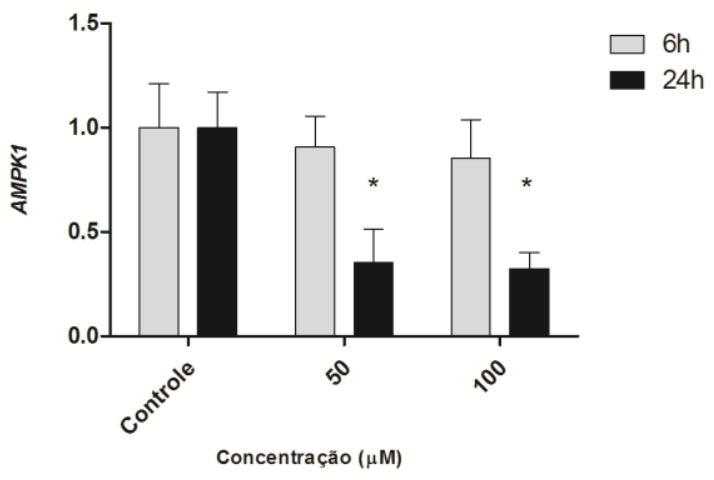

D

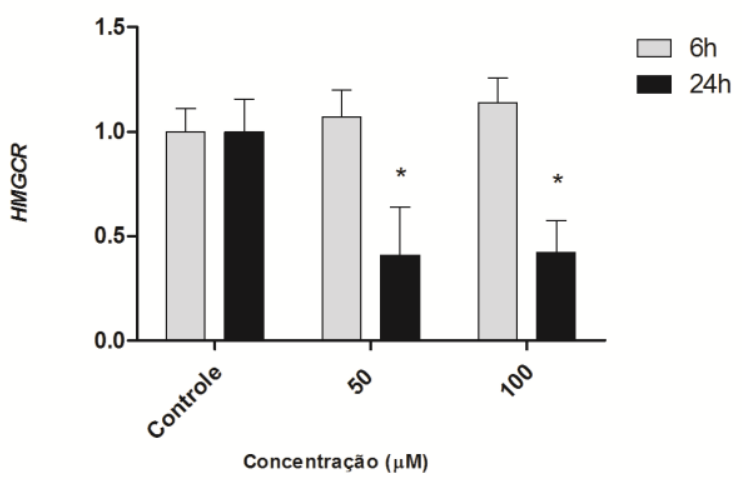

$\mathbf{E}$

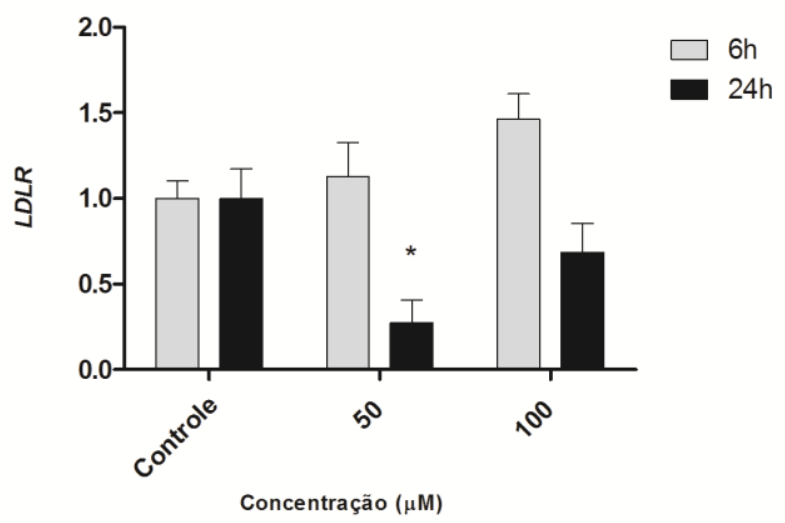


Fonte: Marques, M.R. (2017).

As vias metabólicas do colesterol são altamente integradas e perturbações a uma via podem provocar respostas compensatórias ou complementares de outra via. Assim, o presente estudo levanta a possibilidade de que o mesmo peptídeo ou hidrolisado pode atuar em diferentes rotas metabólicas para reduzir o colesterol. A AMPK1 fosforila e inativa um grande número de enzimas metabólicas envolvidas no metabolismo dos lípideos, com o intuito de manter o estado de energia celular. Ele é ativado na presença de estresse metabólico, mobilizando reservas de energia e quando superexpresso inativa a enzima HMGCR e a produção de colesterol no fígado. Contudo, mesmo com uma redução de expressão da $A M P K 1$, o RNAm HMGCR permanece em níveis baixos, corroborando a hipótese de modulação por atuação do gene SREBP2.

Outro achado importante foi que este experimento não detectou qualquer evidência da regulação negativa da $L X R \alpha$ e aumento de RNAm $L D L R$. Os LXRs são receptores nucleares ativados por ligantes que atuam como sensores de colesterol; no fígado, o LXR promove a conversão de colesterol em ácidos biliares. Este resultado contraditório pode ser devido ao fato de que os SREBPs são ativados em resposta a baixa concentração de colesterol celular, ao passo que a $L X R s$ são ativados por concentração elevada de colesterol.

Estes resultados estão de acordo com estudos recentes com peptídeos de glicinina de soja, aminoácidos isolados leucina e valina, leite desnatado e caseína que são capazes de interferir no metabolismo do colesterol pela modulação da via SREBP2 (CHEN e REIMER, 2009; LAMMI et al., 2014; LAMMI et al., 2015). Devido ao peptídeo MELNAVSVVSH não ter sido eficaz como regulador de expressão dos genes (APÊNDICE B), este estudo corrobora a hipótese de que a ordem específica de aminoácidos dentro da estrutura do peptídeo bioativo é mais importante que a composição de aminoácido e a massa molecular; confirma também a sequencia correta predita (LIYANAGE et al., 2010). Os resultados desta investigação complementam os estudos anteriores do nosso grupo de pesquisa em seres humanos. O consumo de $25 \mathrm{~g} /$ dia por seres humanos de proteína de feijão caupi foi responsável por reduzir o colesterol total, colesterol LDL e a proteína ApoB-100 (FROTA et al., 2015). 


\section{Conclusões}

A fração $\leq 3 \mathrm{kDa}$ do hidrolisado e todos os peptídeos testados foram capazes de insolubilizar o colesterol in vitro.

As mudanças no tamanho das micelas mistas de colesterol na presença da fração $\leq 3 \mathrm{kDa}$ do hidrolisado e dos peptídeos, não estão relacionadas com a capacidade de insolubilizar colesterol no modelo in vitro. Contudo, experimentos espectroscópicos tomados em conjunto sugerem que o mecanismo de diminuição de colesterol dos peptídeos está mais relacionado a uma mudança na composição micelar; ligação e/ou insolubilização de colesterol, fosfatidilcolina e ácidos biliares.

O mecanismo de insolubilização do colesterol pela fração $\leq 3 \mathrm{kDa}$ do hidrolisado está relacionada com a interação com a fosfatidilcolina. Essa fração é incapaz de se ligar aos ácidos biliares, ao menos significativamente.

O mecanismo de insolubilização do colesterol dos peptídeos LLNPDDEQL, FFFGQDGGSKGEE e LNL parece ser uma sinergia entre a interação com ácidos biliares e a fosfatidilcolina. Mesmo assim, o efeito nas micelas é bem inferior comparado aos resultados encontrados no hidrolisado.

Constata-se que, diferentemente dos polifenóis e/ou fitoesteróis o mecanismo de competição pelo espaço intramicelar com o colesterol se dá pela interação indireta com os componentes micelares e não diretamente com o colesterol, em concentrações maiores, porém, ainda fisiológicas.

Considerando a via endógena do metabolismo do colesterol, os peptídeos de feijão caupi são permeáveis no intestino e podem atuar a nível genético.

A fração $\leq 3 \mathrm{kDa}$ de hidrolisado de de caupi pode interferir na absorção intestinal de colesterol, inibindo a expressão de NPC1L1.

O peptídeo MELNAVSVVHS reduziu a expressão do fator de transcrição SREBP2 (consequentemente reduzindo HMGCR e $L D L R$ ).

Não obstante suas limitações, este estudo complementa estudos anteriores de nosso grupo de pesquisa em seres humanos, ampliando nosso conhecimento elucidando o mecanismo e apontado o fígado como o local de ação principal de peptídeos de caupi. 


\section{Referências}

AFONSO, M. S. Avaliação do efeito do extrato aquoso e da fração fenólica livre do Alecrim (Rosmarinus officinalis L.) sobre o estado antioxidante e o perfil lipídico em ratos com hipercolesterolemia induzida pela dieta. 2010. Dissertação(Mestrado em Ciência dos Alimentos) Universidade de São Paulo, São Paulo.

AO, J.; LI, B. Stability and antioxidative activities of casein peptide fractions during simulated gastrointestinal digestion in vitro: Charge properties of peptides affect digestive stability. Food Research International, v. 52, n. 1, p. 334-341, 2013.

ARAI, S. Functional food science in Japan: state of the art. Biofactors, v. 12, n. 1 - 4, p. 13-16, 2000. ISSN 1872-8081.

ARNOLDI, A. et al. Soy protein components active in the regulation of cholesterol homeostasis. Biologically-Active Phytochemicals in Food, n. 269, p. 103-106, 2001. ISSN 0260-6291..

BEGAN, G. et al. Interaction of curcumin with phosphatidylcholine: a spectrofluorometric study. Journal of agricultural and food chemistry, v. 47, n. 12, p. 4992-4997, 1999.

BETTZIECHE, A. et al. Differing Effect of Protein Isolates from Different Cultivars of Blue Lupin on Plasma Lipoproteins of Hypercholesterolemic Rats. Bioscience Biotechnology and Biochemistry, v. 72, n. 12, p. 3114-3121, Dec 2008.

BIASUTTI, E. A. R. et al. Action of pancreatin for obtaining whey protein hydrolysates with high oligopeptide contents. Revista Brasileira De Ciencias Farmaceuticas, v. 44, n. 1, p. 51-60, Jan-Mar 2008. ISSN 1516-9332.

BLIGH, E. G.; DYER, W. J. A rapid method of total lipid extraction and purification. Canadian Journal of Biochemistry and Physiology, v. 37, n. 8, p. 911-917, 1959. ISSN 0576-5544.

BROWN, M. S.; GOLDSTEIN, J. L. The SREBP Pathway: Regulation of Cholesterol Metabolism by Proteolysis of a Membrane-Bound Transcription Factor. Cell, v. 89, n. 3, p. 331-340, 1997.

CAREY, M. C. Critical tables for calculating the cholesterol saturation of native bile. Journal of Lipid Research, v. 19, n. 8, p. 945-955, 1978.

CARR, T. P.; JESCH, E. D. Food components that reduce cholesterol absorption. Advances in food and nutrition research, v. 51, p. 165-204, 2006. ISSN 10434526. 
CATAPANO, A. L. et al. 2016 ESC/EAS Guidelines for the Management of Dyslipidaemias. European Heart Journal, v. 37, n. 39, p. 2999-3058, 2016. ISSN 0195-668X.

CHEN, Q.; REIMER, R. A. Dairy protein and leucine alter GLP-1 release and mRNA of genes involved in intestinal lipid metabolism in vitro. Nutrition, v. 25, n. 3, p. 340-349, Mar 2009. ISSN 0899-9007.

COHEN, L. H. et al. Effects of compactin, mevalonate and low-density lipoprotein on 3-hydroxy-3-methylglutaryl-coenzyme-a reductase-activity and low-density-lipoproteinreceptor activity in the human hepatoma-cell line Hep-G2. Biochemical Journal, v. 222, n. 1, p. 35-39, 1984 1984. ISSN 0264-6021.

CONSONNI, A. et al. Cloning, yeast expression, purification and biological activity of a truncated form of the soybean $7 \mathrm{~S}$ globulin alpha ' subunit involved in Hep G2 cell cholesterol homeostasis. Journal of Nutritional Biochemistry, v. 21, n. 9, p. 887891, Sep 2010. ISSN 0955-2863.

CORETA-GOMES, F. M. et al. Quantification of cholesterol solubilized in bile salt micellar aqueous solutions using $\mathrm{C}-13$ nuclear magnetic resonance. Analytical Biochemistry, v. 427, n. 1, p. 41-48, Aug 1 2012. ISSN 0003-2697.

COSKUN, A.; SERTESER, M.; UNSAL, I. Inhibition of cholesterol biosynthesis in hypercholesterolemia - is it the right choice? Journal of Medical Biochemistry, v. 32, n. 1, p. 16-19, Jan-Mar 2013. ISSN 1452-8258.

DEL MAR YUST, M. et al. Hypocholesterolaemic and antioxidant activities of chickpea (Cicer arietinum L.) protein hydrolysates. Journal of the Science of Food and Agriculture, v. 92, n. 9, p. 1994-2001, Jul 2012. ISSN 0022-5142.

DING, L. et al. Transport of Antihypertensive Peptide RVPSL, Ovotransferrin 328-332, in Human Intestinal Caco-2 Cell Monolayers. Journal of Agricultural and Food Chemistry, v. 63, n. 37, p. 8143-8150, Sep 23 2015. ISSN 0021-8561.

DONOVAN, J.; TIMOFEYEVA, N.; CAREY, M. Influence of total lipid concentration, bile salt: lecithin ratio, and cholesterol content on inter-mixed micellar/vesicular (nonlecithin-associated) bile salt concentrations in model bile. Journal of lipid research, v. 32, n. 9, p. 1501-1512, 1991. ISSN 0022-2275.

EMBRAPA. Unidade de execução de âmbito estadual de Rio Branco.Cultura do caupi no estado do Acre.: Folder 1987.

ERICKSON, S. K.; FIELDING, P. E. Parameters of cholesterol metabolism in the human hepatoma cell line, Hep-G2. Journal of Lipid Research, v. 27, n. 8, p. 875883, 1986. 
ESPEJO-CARPIO, F. J. et al. Effect of digestive enzymes on the bioactive properties of goat milk protein hydrolysates. International Dairy Journal, v. 54, p. 21-28, 2016. ISSN 0958-6946.

ESTATÍSTICA, I. B. D. G. E. Sistema IBGE de recuperação automatica - SIDRA: Banco de dados agregados 2002.

FERREIRA, E. D. et al. Soy beta-Conglycinin (7S Globulin) Reduces Plasma and Liver Cholesterol in Rats Fed Hypercholesterolemic Diet. Journal of Medicinal Food, v. 14, n. 1-2, p. 94-100, Jan 2011. ISSN 1096-620X.

FITZGERALD, C. et al. Heart Health Peptides from Macroalgae and Their Potential Use in Functional Foods. Journal of Agricultural and Food Chemistry, v. 59, n. 13, p. 6829-6836, Jul 2011. ISSN 0021-8561.

FREIRE FILHO, F. R. et al. Características botânicas e agronômicas de cultivares de feijão

macassar (Vigna unguiculata (L.) Walp.). (EMBRAPA-UEPAE de Teresina. Boletim de Pesquisa, 4). Teresina: 45 p. 1981.

FROTA, K. D. M. G. Efeito do feijão caupi (Vigna unguiculata L. Walp) e da proteína isolada no metabolismo lipídico em hamsters hipercolesterolemizados. 2007. Dissertação (Mestrado em Nutrição Humana Aplicada) Universidade de São Paulo, São Paulo.

FROTA, K. D. M. G. et al. Cowpea protein reduces LDL-cholesterol and apolipoprotein B concentrations, but does not improve biomarkers of inflammation or endothelial dysfunction in adults with moderate hypercholesterolemia. Nutricion Hospitalaria, v. 31, n. 4, p. 1611-1619, Apr 2015. ISSN 0212-1611.

. Cholesterol-lowering properties of whole cowpea seed and its protein isolate in hamsters. Journal of Food Science, v. 73, n. 9, p. H235-H240, 2008. ISSN $0022-$ 1147.

- Utilização da farinha de feijão-caupi (Vigna unguiculata L. Walp) na elaboração de produtos de panificação. Ciência e Tecnologia de Alimentos, v. 30, p. 44-50, 2010. ISSN 0101-2061.

FROTA, K. M. G. Efeito da proteína de feijão caupi (Vigna unguiculata L. Walp) nos marcadores de risco para doença cardiovascular em pacientes hipercolesterolêmicos. 2011. Dissertação (Mestrado Nutrição em Saúde Pública) Universidade de São Paulo, São Paulo. 
FROTA, K. M. G. et al. Cholesterol-Lowering Properties of Whole Cowpea Seed and Its Protein Isolate in Hamsters. Journal of Food Science, v. 73, n. 9, p. H235-H240, 2008. ISSN 0022-1147.

GALLEGO, M. et al. Transepithelial transport of dry-cured ham peptides with ACE inhibitory activity through a Caco-2 cell monolayer. Journal of Functional Foods, v. 21, p. 388-395, Mar 2016. ISSN 1756-4646.

GENVIGIR, F. D. et al. ABCA1 and ABCG1 expressions are regulated by statins and ezetimibe in Caco-2 cells. Drug metabolism and drug interactions, v. 26, n. 1, p. 33-36, 2011. ISSN 2191-0162.

ABCA1 and ABCG1 expressions are regulated by statins and ezetimibe in

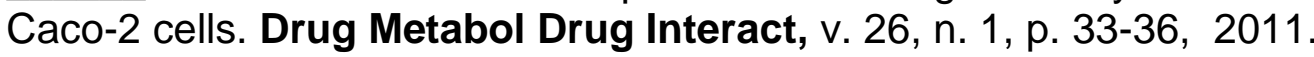

GENVIGIR, F. D. V. et al. Effects of lipid-lowering drugs on reverse cholesterol transport gene expressions in peripheral blood mononuclear and HepG2 cells. Pharmacogenomics, v. 11, n. 9, p. 1235-1246, Sep 2010. ISSN 1462-2416.

GLEESON, J. P. et al. Stability, toxicity and intestinal permeation enhancement of two food-derived antihypertensive tripeptides, Ile-Pro-Pro and Leu-Lys-Pro. Peptides, v. 71, p. 1-7, Sep 2015. ISSN 0196-9781.

GOLDSTEIN, J. L.; BROWN, M. S. Regulation of the mevalonate pathway. Nature, v. 343, n. 6257, p. 425-430, 1990.

GONÇALVES, A. et al. Cowpea (Vigna unguiculata L. Walp), a renewed multipurpose crop for a more sustainable agri-food system: nutritional advantages and constraints. Journal of the Science of Food and Agriculture, v. 96, n. 9, p. 2941-2951, 2016.

GREENSPAN, P.; FOWLER, S. D. Spectrofluorometric studies of the lipid probe, nile red. Journal of Lipid Research, v. 26, n. 7, p. 781-789, 1985.

HANSEN, S. A.; ASHLEY, A.; CHUNG, B. M. Complex Dietary Protein Improves Growth Through a Complex Mechanism of Intestinal Peptide Absorption and Protein Digestion. Journal of Parenteral and Enteral Nutrition, v. 39, n. 1, p. 95-103, Jan 2015. ISSN 0148-6071.

HERNANDEZ-LEDESMA, B.; CONTRERAS, M. D.; RECIO, I. Antihypertensive peptides: Production, bioavailability and incorporation into foods. Advances in Colloid and Interface Science, v. 165, n. 1, p. 23-35, Jun 2011. ISSN 0001-8686.

HERNELL, O.; STAGGERS, J. E.; CAREY, M. C. Physical-chemical behavior of dietary and biliary lipids during intestinal digestion and absorption. 2. Phase analysis and aggregation states of luminal lipids during duodenal fat digestion in healthy adult human beings. Biochemistry, v. 29, n. 8, p. 2041-2056, 2013/06/22 1990. 
HOLTON, T. A. et al. CPPpred: prediction of cell penetrating peptides. Bioinformatics, v. 29, n. 23, p. 3094-3096, 2013.

HOYLE, N. T.; MERRITT, J. H. Quality of fish-protein hydrolysates from herring (Clupea-harengus). Quality of fish-protein hydrolysates from herring (Clupeaharengus). . Journal of Food Science, v. 59, n. 1, p. 76-\&amp;, Jan-Feb 1994. ISSN 0022-1147.

IKONEN, E. Cellular cholesterol trafficking and compartmentalization. Nature Reviews Molecular Cell Biology, v. 9, n. 2, p. 125-138, Feb 2008. ISSN 1471-0072.

INSTITUTO BRASILEIRO DE GEOGRAFIA, E. E. Sistema IBGE de recuperação automatica - SIDRA: Banco de dados agregados 2002.

IVANOV, V. T. et al. Hemoglobin as a source of endogenous bioactive peptides: The concept of tissue-specific peptide pool. Biopolymers - Peptide Science Section, v. 43, n. 2, p. 171-188, 1997.

KHOSHAKHLAGH, P. et al. Fasted-State Simulated Intestinal Fluid "FaSSIF-C", a Cholesterol Containing Intestinal Model Medium for In Vitro Drug Delivery Development. Journal of Pharmaceutical Sciences, v. 104, n. 7, p. 2213-2224, 2015.

KIDAMBI, S.; PATEL, S. B. Cholesterol and non-cholesterol sterol transporters: ABCG5, ABCG8 and NPC1L1: a review. Xenobiotica, v. 38, n. 7-8, p. 1119-1139, 2008 2008. ISSN 0049-8254.

KOBAYASHI, M. et al. Epigallocatechin Gal late Decreases the Micellar Solubility of Cholesterol via Specific Interaction with Phosphatidylcholine. Journal of Agricultural and Food Chemistry, v. 62, n. 13, p. 2881-2890, Apr 22014.

KORHONEN, H.; PIHLANTO, A. Bioactive peptides: production and functionality. International dairy journal, v. 16, n. 9, p. 945-960, 2006.

LAEMMLI, U. K. Cleavage of structural proteins during the assembly of the head of bacteriophage T4. nature, v. 227, n. 5259, p. 680-685, 1970. ISSN 0028-0836.

LAFARGA, T.; HAYES, M. Bioactive peptides from meat muscle and by-products: generation, functionality and application as functional ingredients. Meat science, $v$. 98, n. 2, p. 227-239, 2014. ISSN 0309-1740.

LAMMI, C.; ZANONI, C.; ARNOLDI, A. IAVPGEVA, IAVPTGVA, and LPYP, three peptides from soy glycinin, modulate cholesterol metabolism in HepG2 cells through the activation of the LDLR-SREBP2 pathway. Journal of Functional Foods, v. 14, p. 469-478, Apr 2015. ISSN 1756-4646. 
LAMMI, C. et al. Peptides Derived from Soy and Lupin Protein as DipeptidylPeptidase IV Inhibitors: In Vitro Biochemical Screening and in Silico Molecular Modeling Study. Journal of Agricultural and Food Chemistry, v. 64, n. 51, p. 96019606, 2016.

. Lupin Peptides Lower Low-Density Lipoprotein (LDL) Cholesterol through an Up-regulation of the LDL Receptor/Sterol Regulatory Element Binding Protein 2 (SREBP2) Pathway at HepG2 Cell Line. Journal of Agricultural and Food Chemistry, v. 62, n. 29, p. 7151-7159, Jul 23 2014. ISSN 0021-8561.

LECERF, J.-M.; DE LORGERIL, M. Dietary cholesterol: from physiology to cardiovascular risk. British Journal of Nutrition, v. 106, n. 01, p. 6-14, 2011. ISSN 1475-2662.

LEE-RUECKERT, M. et al. The role of the gut in reverse cholesterol transport-focus on the enterocyte. Progress in lipid research, v. 52, n. 3, p. 317-328, 2013. ISSN 0163-7827.

LERNER, A.; MATTHIAS, T. Changes in intestinal tight junction permeability associated with industrial food additives explain the rising incidence of autoimmune disease. Autoimmunity Reviews, v. 14, n. 6, p. 479-489, Jun 2015. ISSN 1568-9972.

LI, J.; LI, Y.; GUO, S. The binding mechanism of lecithin to soybean $11 \mathrm{~S}$ and $7 \mathrm{~S}$ globulins using fluorescence spectroscopy. Food Science and Biotechnology, v. 23, n. 6, p. 1785-1791, 2014. ISSN 1226-7708.

LIANG, Y. T. et al. Cholesterol-Lowering Activity of Sesamin Is Associated with DownRegulation on Genes of Sterol Transporters Involved in Cholesterol Absorption. Journal of Agricultural and Food Chemistry, v. 63, n. 11, p. 2963-2969, 2015.

LIVAK, K. J.; SCHMITTGEN, T. D. Analysis of relative gene expression data using real-time quantitative PCR and the 2(-Delta Delta $C(T)$ ) Method. Methods, v. 25, n. 4, p. 402-8, Dec 2001. ISSN 1046-2023 (Print)

1046-2023.

LIYANAGE, R. et al. Preparation method modulates hypocholesterolaemic responses of potato peptides. Journal of Functional Foods, v. 2, n. 2, p. 118-125, Apr 2010. ISSN 1756-4646.

MA, B. et al. PEAKS: powerful software for peptide de novo sequencing by tandem mass spectrometry. Rapid Communications in Mass Spectrometry, v. 17, n. 20, p. 2337-2342, 2003. 
MAESTRI, E.; MARMIROLI, M.; MARMIROLI, N. Bioactive peptides in plant-derived foodstuffs. Foodomics - Novel insights in food and nutrition domains, v. 147, p. 140-155, 2016.

MARIANECCI, C. et al. Interaction of pH-sensitive non-phospholipid liposomes with cellular mimetic membranes. Biomedical Microdevices, v. 15, n. 2, p. 299-309, 2012.

MARQUES, M. R. Ação hipocolesterolêmica de hidrolisados de feijões caupi (Vigna unguiculata L. Walp). 2013. Dissertação (Mestrado em Nutrição em Saúde Pública) Faculdade de Saúde Pública, Universidade de São Paulo, São Paulo.

MARQUES, M. R. et al. Proteolytic hydrolysis of cowpea proteins is able to release peptides with hypocholesterolemic activity. Food Research International, v. 77, n. 1, p. 43-48, 2015.

Peptides from cowpea present antioxidant activity, inhibit cholesterol synthesis and its solubilisation into micelles. Food Chemistry, v. 168, p. 288-293, Feb 1 2015. ISSN 0308-8146.

An in vitro analysis of the total phenolic content, antioxidant power, physical, physicochemical, and chemical composition of Terminalia Catappa Linn fruits. Ciência e Tecnologia de Alimentos, v. 32, p. 209-213, 2012. ISSN 0101-2061.

MARRINK, S. J.; MARK, A. E. Molecular dynamics simulations of mixed micelles modeling human bile. Biochemistry, v. 41, n. 17, p. 5375-5382, Apr 30 2002. ISSN 0006-2960.

MATHEW, A. et al. Alzheimer's disease: Cholesterol a menace? Brain Research Bulletin, v. 86, n. 1-2, p. 1-12, 2011.

MATSUOKA, K. et al. Competitive solubilization of cholesterol and $\beta$-sitosterol with changing biliary lipid compositions in model intestinal solution. Chemistry and Physics of Lipids, v. 165, n. 1, p. 7-14, 2012.

MATTHAN, N. R.; LICHTENSTEIN, A. H. Approaches to measuring cholesterol absorption in humans. Atherosclerosis, v. 174, n. 2, p. 197-205, 2004. ISSN 00219150.

MEGIAS, C. et al. Sunflower Protein Hydrolysates Reduce Cholesterol Micellar Solubility. Plant Foods for Human Nutrition, v. 64, n. 2, p. 86-93, Jun 2009. ISSN 0921-9668.

MEGÍAS, C. et al. Stability of sunflower protein hydrolysates in simulated gastric and intestinal fluids and Caco-2 cell extracts. Food Science and Technology, v. 42, n. 9, p. 1496-1500, 2009. ISSN 0023-6438. 
MEHTIEV, A. R. et al. Regulation of cholesterol biosynthesis and metabolism in Hep G2 cells by $\Delta 8(14)-15$-ketoergostane derivatives. Biochemistry (Moscow) Supplement Series B: Biomedical Chemistry, v. 4, n. 3, p. 251-257, 2010.

MENDONCA, S. et al. Amaranth protein presents cholesterol-lowering effect. Food Chemistry, v. 116, n. 3, p. 738-742, Oct 1 2009. ISSN 0308-8146.

MENIN, L. et al. High throughput screening of bradykinin-potentiating peptides in Bothrops moojeni snake venom using precursor ion mass spectrometry. v. 51, n. 7, p. 1288-1302, 2008.

MOHAN, A.; UDENIGWE, C. C. Towards the design of hypolipidaemic peptides: Deoxycholate binding affinity of hydrophobic peptide aggregates of casein plastein. Journal of Functional Foods, v. 18, p. 129-136, 2015. ISSN 1756-4646.

MOSCHETTA, A. et al. Accurate separation of vesicles, micelles and cholesterol crystals in supersaturated model biles by ultracentrifugation, ultrafiltration and dialysis. Biochimica Et Biophysica Acta-Molecular and Cell Biology of Lipids, v. 1532, n. 1-2, p. 15-27, May 31 2001. ISSN 1388-1981.

Sphingomyelin exhibits greatly enhanced protection compared with egg yolk phosphatidylcholine against detergent bile salts. Journal of Lipid Research, v. 41, n. 6, p. 916-924, Jun 2000. ISSN 0022-2275.

MOUSINHO, F. E. P. Viabilidade econômica do feijão caupi no Estado do Piauí. 2005. Tese (Doutorado em Irrigação e Drenagem)-Escola Superior de Agricultura" Luiz de Queiroz", Universidade de São Paulo, Piracicaba.

NAGAOKA, S. et al. Identification of novel hypocholesterolemic peptides derived from bovine milk beta-lactoglobulin. Biochemical and Biophysical Research Communications, v. 281, n. 1, p. 11-17, 2001. ISSN 0006-291X.

. Soystatin (VAWWMY), a Novel Bile Acid-Binding Peptide, Decreased Micellar Solubility and Inhibited Cholesterol Absorption in Rats. Bioscience, Biotechnology, and Biochemistry, v. 74, n. 8, p. 1738-1741, 2010.

NES, W. D. Biosynthesis of Cholesterol and Other Sterols. Chemical Reviews, v. 111 , n. 10, p. 6423-6451, Oct 2011. ISSN 0009-2665.

PAK, V. V. et al. Peptide design of a competitive inhibitor for HMG-CoA reductase based on statin structure. Biopolymers, v. 84, n. 6, p. 586-594, 2006. ISSN 00063525. 
Isolation and identification of peptides from soy 11S-globulin with hypocholesterolemic activity. Chemistry of Natural Compounds, v. 41, n. 6, p. 710714, Nov-Dec 2005. ISSN 0009-3130.

PAWAR, V. K. et al. Targeting of gastrointestinal tract for amended delivery of protein/peptide therapeutics: strategies and industrial perspectives. Journal of Controlled Release, v. 196, p. 168-183, 2014.

PICARIELLO, G. et al. Transport across Caco-2 monolayers of peptides arising from in vitro digestion of bovine milk proteins. Food Chemistry, v. 139, n. 1-4, p. 203-212, Jul 1 2013. ISSN 0308-8146.

PIMENTA, D. C.; LEBRUN, I. Cryptides: Buried secrets in proteins. Peptides, v. 28, n. 12, p. 2403-2410, Dec 2007. ISSN 0196-9781.

POPJAK., G. In: PRESS, P. (Ed.). Lipids: Chemistry, Biochemistry and Nutrition. New York: Mead, J. F., Alfin-Slater, R. B., Howton, D. R., Popjak., G.,, 1986. p.296.

POTTER, S. M. Soy Protein and Cardiovascular Disease: The Impact of Bioactive Components in Soy. Nutrition Reviews, v. 56, n. 8, p. 231-235, 1998.

PÉREZ-GÁLVEZ, R. et al. Bile acid binding capacity of fish protein hydrolysates from discard species of the West Mediterranean Sea. Food \& function, v. 6, n. 4, p. 12611267, 2015.

RANALLETTA, M. et al. Decreased atherosclerosis in low-density lipoprotein receptor knockout mice transplanted with Abcg1-/- bone marrow. Arteriosclerosis, thrombosis, and vascular biology, v. 26, n. 10, p. 2308-2315, 2006. ISSN 10795642.

RENUKUNTLA, J. et al. Approaches for enhancing oral bioavailability of peptides and proteins. International journal of pharmaceutics, v. 447, n. 1, p. 75-93, 2013. ISSN 0378-5173.

RUTHERFURD, S. M. Methodology for determining degree of hydrolysis of proteins in hydrolysates: A Review. Journal of Aoac International, v. 93, n. 5, p. 1515-1522, Sep-Oct 2010. ISSN 1060-3271.

RYDER, K. et al. Towards generation of bioactive peptides from meat industry waste proteins: Generation of peptides using commercial microbial proteases. Food Chemistry, v. 208, p. 42-50, $2016 .$.

SCURIATTI, M.; TOMÁS, M.; WAGNER, J. Influence of soybean protein isolatesphosphatidycholine interaction on the stability on oil-in-water emulsions. Journal of the American Oil Chemists' Society, v. 80, n. 11, p. 1093-1100, 2003. ISSN 0003021X. 
SILVESTRE, M. P. C.; HAMON, M.; YVON, M. Analysis of protein hydrolysates .2. characterization of casein hydrolysates by a rapid peptide quantification method. Journal of Agricultural and Food Chemistry, v. 42, n. 12, p. 2783-2789, Dec 1994. ISSN 0021-8561.

SIRTORI, C. R. et al. Proteins of White Lupin Seed, a Naturally Isoflavone-Poor Legume, Reduce Cholesterolemia in Rats and Increase LDL Receptor Activity in HepG2 Cells. The Journal of Nutrition, v. 134, n. 1, p. 18-23, 2004.

SMET, E. D.; MENSINK, R. P.; PLAT, J. Effects of plant sterols and stanols on intestinal cholesterol metabolism: suggested mechanisms from past to present. Molecular nutrition \& food research, v. 56, n. 7, p. 1058-1072, 2012. ISSN 16134133.

SOARES, R. A. M. Identificação de peptídeos hipocolesterolemizantes do isolado protéico do grão de amaranto (Amaranthus cruentus L. BRS-Alegria). 2008. (Dissertação (Mestrado em Nutrição em saúde pública)). Universidade de São Paulo. Faculdade de Saúde Pública.

STAELS, B.; HANDELSMAN, Y.; FONSECA, V. Bile acid sequestrants for lipid and glucose control. Current diabetes reports, v. 10, n. 1, p. 70-77, 2010. ISSN 15344827.

STUART, M. C. A.; VAN DE PAS, J. C.; ENGBERTS, J. The use of Nile Red to monitor the aggregation behavior in ternary surfactant-water-organic solvent systems. Journal of physical organic chemistry, v. 18, n. 9, p. 929-934, 2005. ISSN 08943230.

SUDHAHAR, V.; KUMAR, S. A.; VARALAKSHMI, P. Role of lupeol and lupeol linoleate on lipemic-oxidative stress in experimental hypercholesterolemia. Life Sciences, v. 78, n. 12, p. 1329-1335, 2006. ISSN 0024-3205.

TACHIBANA, S. et al. Cholesterol and plant sterol efflux from cultured intestinal epithelial cells is mediated by ATP-binding cassette transporters. Bioscience Biotechnology and Biochemistry, v. 71, n. 8, p. 1886-1895, Aug 2007. ISSN $0916-$ 8451.

TANABE, S. Short Peptide Modules for Enhancing Intestinal Barrier Function. Current Pharmaceutical Design, v. 18, n. 6, p. 776-781, Feb 2012. ISSN 1381-6128.

THIAM, A. R.; FARESE, R. V., JR.; WALTHER, T. C. The biophysics and cell biology of lipid droplets. Nature Reviews Molecular Cell Biology, v. 14, n. 12, p. 775-786, Dec 2013. ISSN 1471-0072. 
TIENGO, A.; MOTTA, E. M. P.; NETTO, F. M. Chemical composition and bile acid binding activity of products obtained from amaranth (Amaranthus cruentus) seeds. Plant foods for human nutrition, v. 66, n. 4, p. 370-375, 2011. ISSN 0921-9668.

VANDESOMPELE, J. et al. Accurate normalization of real-time quantitative RT-PCR data by geometric averaging of multiple internal control genes. Genome Biology, v. 3, n. 7, 2002 2002. ISSN 1474-760X.

VIOLLET, B. et al. AMP-activated protein kinase in the regulation of hepatic energy metabolism: from physiology to therapeutic perspectives. Acta Physiologica, v. 196, n. 1, p. 81-98, May 2009. ISSN 1748-1708.

WANG, C.; WANG, B.; LI, B. Bioavailability of peptides from casein hydrolysate in vitro: Amino acid compositions of peptides affect the antioxidant efficacy and resistance to intestinal peptidases. Food Research International, v. 81, p. 188-196, Mar 2016. ISSN 0963-9969.

WANG, D.; CAREY, M. Complete mapping of crystallization pathways during cholesterol precipitation from model bile: influence of physical-chemical variables of pathophysiologic relevance and identification of a stable liquid crystalline state in cold, dilute and hydrophilic bile salt-containing systems. Journal of lipid research, v. 37, n. 3, p. 606-630, 1996. ISSN 0022-2275.

WANG, J. et al. Cholesterol-lowering effect of rice bran protein containing bile acidbinding proteins. Bioscience, biotechnology, and biochemistry, v. 79, n. 3, p. 456461, 2015. ISSN 0916-8451.

WASAN, K. M. The role of lymphatic transport in enhancing oral protein and peptide drug delivery. Drug development and industrial pharmacy, v. 28, n. 9, p. 10471058, 2002. ISSN 0363-9045.

WOOLLETT, L. A. et al. Micellar solubilisation of cholesterol is essential for absorption in humans. Gut, v. 55, n. 2, p. 197-204, Feb 2006. ISSN 0017-5749.

YOSHIE-STARK, Y.; WASCHE, A. In vitro binding of bile acids by lupin protein isolates and their hydrolysates. Food Chemistry, v. 88, n. 2, p. 179-184, Nov 2004. ISSN 0308-8146.

YUN, S. M. et al. An in vitro digestion/Caco-2 cell culture system accurately predicts the effects of ascorbic acid and polyphenolic compounds on iron bioavailability in humans. Journal of Nutrition, v. 134, n. 10, p. 2717-2721, Oct 2004. ISSN $0022-$ 3166.

ZHANG, H.; YOKOYAMA, W. H.; ZHANG, H. Concentration-dependent displacement of cholesterol in micelles by hydrophobic rice bran protein hydrolysates. Journal of the Science of Food and Agriculture, v. 92, n. 7, p. 1395-1401, 2012. 
APÊNDICE A - Perfil de $\mathrm{MS}^{2}$ da fragmentação de $\mathrm{m} / \mathrm{z} 1184,5$. O sequenciamento MS/MS foi revisto manualmente e não se pode excluir a possibilidade de sequência $\underline{\mathrm{SH}}$ no C-terminal.

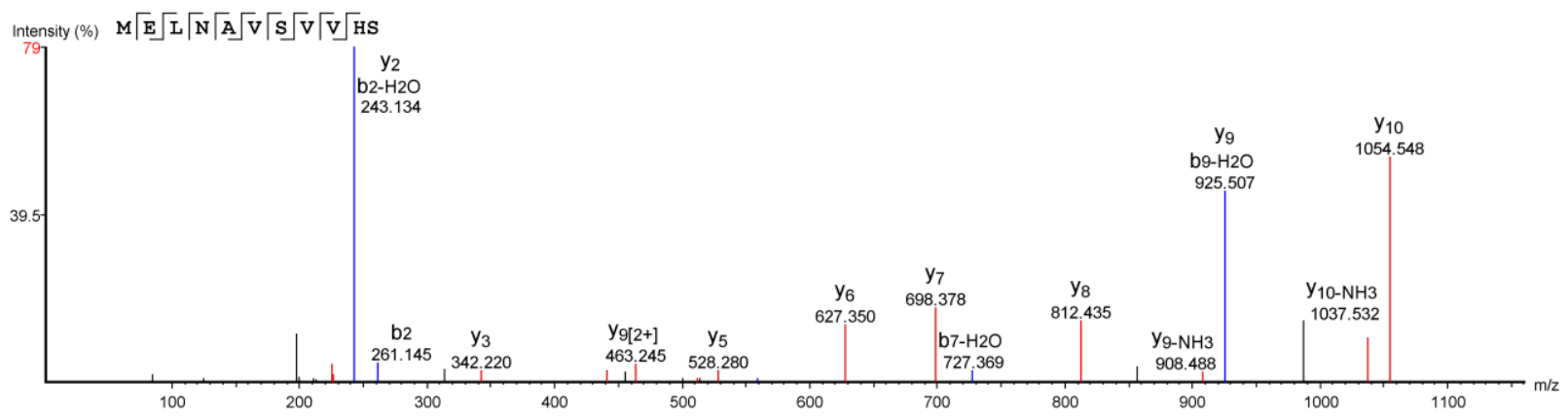


APÊNDICE B - Expressão de RNAm dos gene SREBP2 (A), AMPK1 (B) e LXRa (C), HMGCR (D), LDLR (E) sob diferentes condições de tempo e concentração do peptídeo MELNAVSVVHS.(Média \pm Erro Padrão).

A

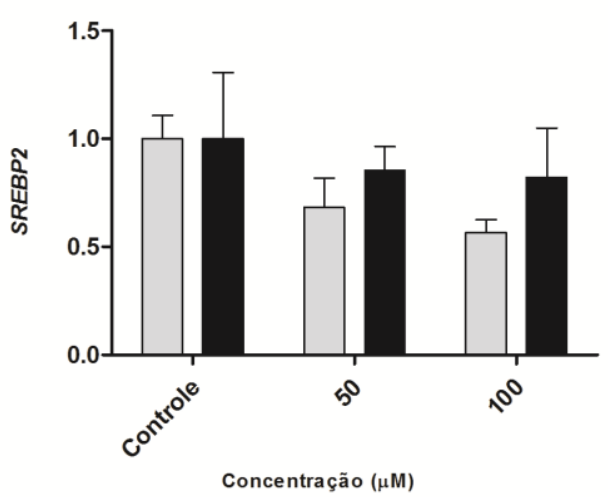

C

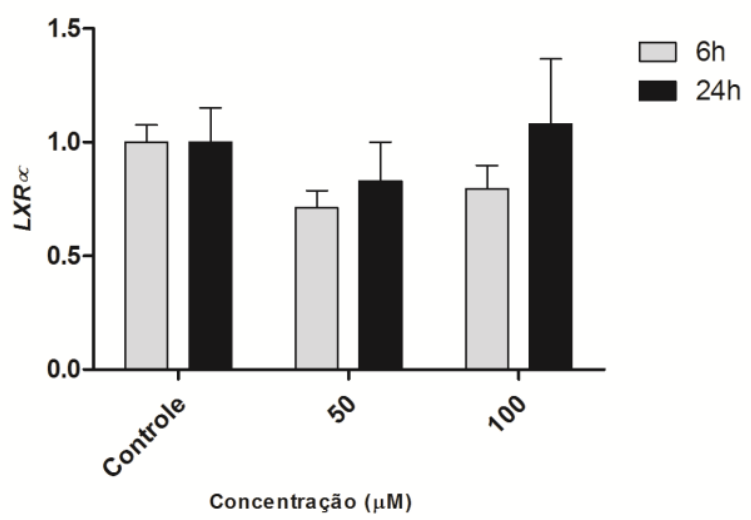

B
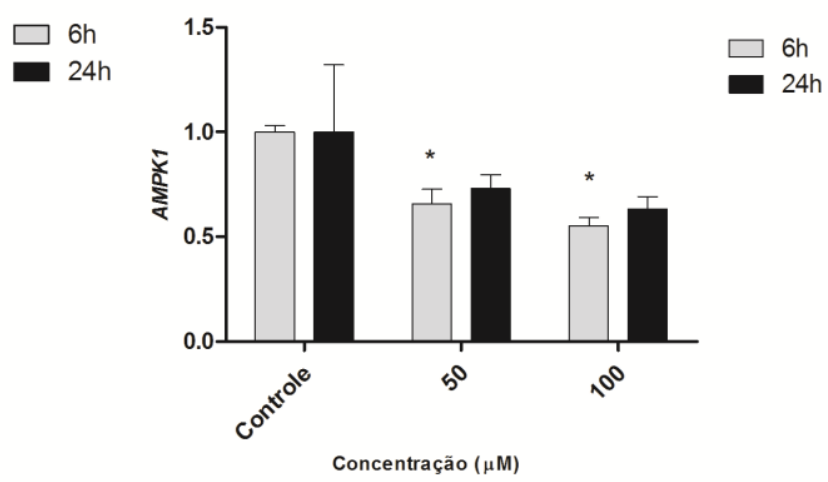

D

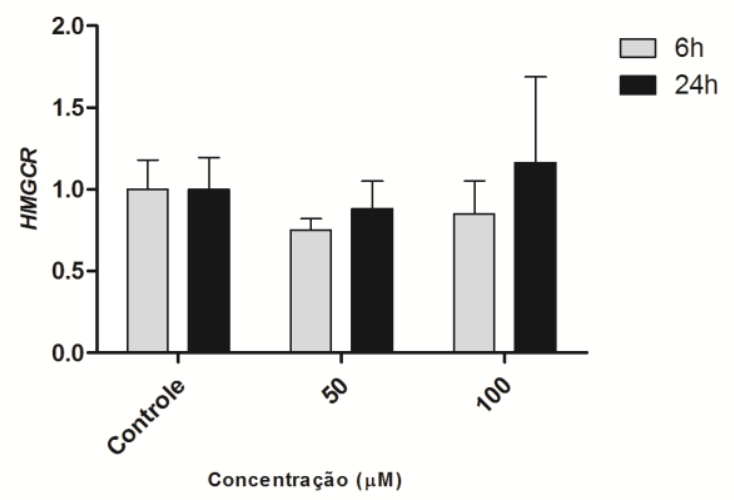

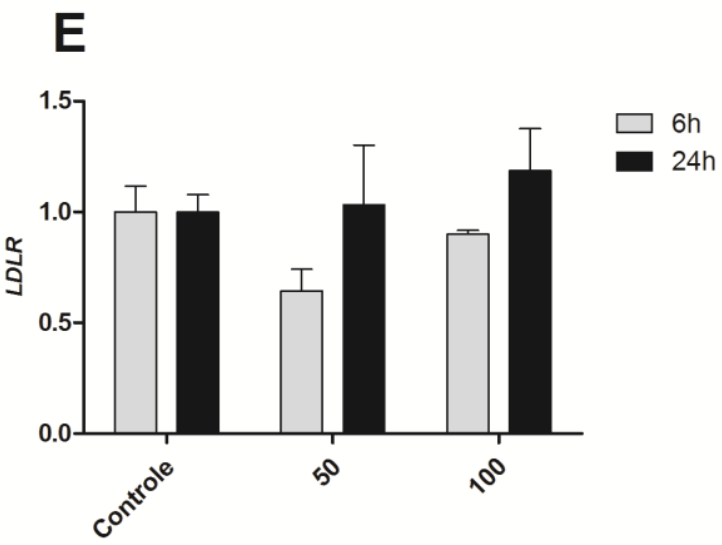

Concentração $(\mu \mathrm{M})$ 
